\title{
Atmospheric Chemistry of Oxygenated Volatile Organic \\ Compounds (OVOCs): Impacts on Air Quality and Climate
}

\author{
A. Mellouki* \\ Environment Research Institute, School of Environmental Science and Engineering, \\ Shandong University, Ji'nan 250100, China \\ ICARE/OSUC, CNRS, 45071 Orléans, France
}

T.J. Wallington

Systems Analytics and Environmental Sciences Department, Ford Motor Company, Mail Drop

RIC-2122, Dearbo rn, MI 48121-2053, USA

J. Chen

Shanghai Key Laboratory of Atmospheric Particle Pollution and Prevention $\left(\mathrm{LAP}^{3}\right)$, Fudan

Tyndall Centre, Shanghai, China

Environment Research Institute, School of Environmental Science and Engineering,

Shandong University, Ji'nan 250100, China 


\section{Contents}

1. Introduction

2. Oxygenated VOCs in the atmosphere

2.1 Biogenic OVOC emissions

2.2 Anthropogenic OVOC emissions

2.3 Background OVOC atmospheric concentrations

3. Atmospheric Chemistry of OVOCs

4. Kinetics and Mechanisms of atmospheric degradation of OVOCs

4.1 Alcohols

4.2 Aldehydes

4.3 Ketones

4.4 Ethers

4.5 Esters

4.6 Carboxylic Acids

4.7 Halogenated OVOCs

4.8 Sulfur/Nitro OVOCs

5. Ozone formation from the atmospheric oxidation of OVOCs

6. Radiative efficiencies and global warming potentials of OVOCs 


\section{Conclusions}

8. Acknowledgments

9. References 


\section{Introduction}

It is hard to overstate the importance of oxygenated organic compounds in atmospheric chemistry. Oxygenated organic compounds are emitted into the atmosphere from natural and man-made sources and they are formed in the atmosphere as oxidation products of all hydrocarbons present in the atmosphere. Oxygenated volatile organic compounds (OVOCs) are generally more reactive than the alkanes from which they are derived. OVOCs play an active role in the sequence of chemical reactions responsible for tropospheric ozone formation in both polluted and remote environments. The HO-radical initiated oxidation of $\mathrm{CH}_{3} \mathrm{OH}$, the most abundant OVOC in the atmosphere, can be represented in simple terms by:

$$
\begin{gathered}
\mathrm{HO}+\mathrm{CH}_{3} \mathrm{OH} \rightarrow \mathrm{H}_{2} \mathrm{O}+\mathrm{CH}_{2} \mathrm{OH} \\
\mathrm{CH}_{2} \mathrm{OH}+\mathrm{O}_{2} \rightarrow \mathrm{HCHO}+\mathrm{HO}_{2} \\
\mathrm{HO}+\mathrm{HCHO} \rightarrow \mathrm{H}_{2} \mathrm{O}+\mathrm{HCO} \\
\mathrm{HCO}+\mathrm{O}_{2} \rightarrow \mathrm{HO}_{2}+\mathrm{CO} \\
\mathrm{HO}+\mathrm{CO} \rightarrow \mathrm{H}+\mathrm{CO}_{2} \\
\mathrm{H}+\mathrm{O}_{2}+\mathrm{M} \rightarrow \mathrm{HO}_{2}+\mathrm{M} \\
3 \times\left(\mathrm{HO}_{2}+\mathrm{NO} \rightarrow \mathrm{HO}^{2} \mathrm{NO}_{2}\right) \\
3 \times\left(\mathrm{NO}_{2}+h v(\lambda<420 \mathrm{~nm}) \rightarrow \mathrm{NO}+\mathrm{O}\left({ }^{3} \mathrm{P}\right)\right) \\
3 \times\left(\mathrm{O}+\mathrm{O}_{2}+\mathrm{M} \rightarrow \mathrm{O}_{3}+\mathrm{M}\right)
\end{gathered}
$$




$$
\text { net: } \quad \mathrm{CH}_{3} \mathrm{OH}+6 \mathrm{O}_{2} \rightarrow 2 \mathrm{H}_{2} \mathrm{O}+3 \mathrm{O}_{3}+\mathrm{CO}_{2}
$$

Aldehydes and ketones absorb at wavelengths greater than $290 \mathrm{~nm}$ and their photolysis is an important radical source promoting photochemical ozone formation.

$$
\begin{gathered}
\mathrm{HCHO}+h v \rightarrow \mathrm{H}+\mathrm{HCO} \\
\mathrm{HCHO}+h v \rightarrow \mathrm{H}_{2}+\mathrm{CO} \\
\mathrm{CH}_{3} \mathrm{C}(\mathrm{O}) \mathrm{CH}_{3}+h v \rightarrow \mathrm{CH}_{3}+\mathrm{CH}_{3} \mathrm{CO} \\
\mathrm{CH}_{3} \mathrm{C}(\mathrm{O}) \mathrm{CH}_{3}+h v \rightarrow 2 \mathrm{CH}_{3}+\mathrm{CO}
\end{gathered}
$$

Photochemistry is responsible for the formation of approximately $4500 \mathrm{Tg}$ of ozone per year in the global troposphere, $90 \%$ of the annual flux, with the remaining approximately $500 \mathrm{Tg}$ transported from the stratosphere. ${ }^{1-2}$ Ozone plays a pivotal role in atmospheric chemistry and is also an important greenhouse gas. IR absorption by ozone is responsible for approximately $10 \%$ of the natural greenhouse effect by the radiatively active species $\mathrm{H}_{2} \mathrm{O}, \mathrm{CO}_{2}, \mathrm{O}_{3}, \mathrm{CH}_{4}$, and $\mathrm{N}_{2} \mathrm{O}$. Historical measurements of ambient ozone levels and modeling studies suggest that as a result of human activities there has been a significant increase in the global tropospheric ozone concentration. The total radiative forcing estimated from increased tropospheric ozone since 1750 is approximately $0.40 \mathrm{~W} \mathrm{~m}^{-2} .4$ In terms of radiative forcing of climate change as a result of human activities since 1750 , changes in ozone account for approximately $17 \%$ of the total anthropogenic radiative forcing of $2.29 \mathrm{~W} \mathrm{~m}^{-2.4}$ 
The ozonolysis of biogenic VOCs such as isoprene and monoterpenes gives multifunctional oxygenated organic compounds with low vapor pressures. These products partition into the aerosol phase leading to the formation of secondary organic aerosols. Secondary organic aerosol formation during the atmospheric oxidation of biogenic organic compounds is estimated at 20-380 $\mathrm{Tg} \mathrm{yr}^{-1}$ globally. ${ }^{4}$ It is well established that aerosols have a substantial influence on climate, however the magnitude of the effect of secondary organic aerosols on climate is unclear ${ }^{4}$ and is not addressed further in the present review.

The atmospheric degradation processes of different classes of OVOCs is summarized in the next sections. The focus is on experimental, gas phase laboratory based data, which have improved our understanding of the atmospheric chemistry of OVOCs. We start with an overview of the sources and representative atmospheric concentrations of OVOCs in Section 2. This is followed by an overview of their general atmospheric chemistry in Section 3. The rate constants for the reactions of the main atmospheric oxidants used to derive the atmospheric lifetimes of the OVOCs and the oxidation routes and products are given in Section 4. We discuss the contribution of OVOCs to ozone formation in the atmosphere based on the concept of photochemical ozone creation potential in Section $5 .^{5-6}$ The radiative efficiencies and global warming potentials of OVOCs is discussed in Section 6. Our intent is to provide an overview of the atmospheric chemistry of OVOCs and their impacts on air quality and climate. For more 
detailed information concerning the gas-phase reactivity of OVOCs in the atmosphere, the reader is directed to recent comprehensive reviews ${ }^{7-9}$ and references therein.

\section{Oxygenated VOCs in the atmosphere}

OVOCs enter the atmosphere by four routes: (i) atmospheric oxidation of hydrocarbons,

(ii) emissions from biological sources such as growing plants, plant debris, and biomass burning,

(iii) evaporation of oxygenated solvents or fuels used in industrial processes, commercial operations, or consumer products, and (iv) incomplete combustion in hydrocarbon-fueled mobile or stationary sources.

On a global basis, by far the most important source of OVOCs is the oxidation of hydrocarbons present in the atmosphere. The atmospheric oxidation of all hydrocarbons gives OVOCs. The simplest hydrocarbon is $\mathrm{CH}_{4}$ which undergoes atmospheric oxidation initiated by reaction with $\mathrm{HO}$ radicals to give $\mathrm{CH}_{3} \mathrm{OH}, \mathrm{HCHO}, \mathrm{HC}(\mathrm{O}) \mathrm{OH}$, and $\mathrm{CH}_{3} \mathrm{OOH}$ which are then further oxidized to give $\mathrm{CO}$ and ultimately $\mathrm{CO}_{2}$. The oxidation of larger hydrocarbons gives rise to a spectacular variety and diversity of OVOCs. Calvert et al. ${ }^{8}$ describe the atmospheric oxidation of $n$-butane leading to the approximately 60 aldehydes, alcohols, organic nitrates, peroxyacyl nitrates, carboxylic acids and percarboxylic acids listed in Table 1. 
Table 1: OVOCs formed in the atmospheric oxidation of n-butane. ${ }^{8}$

\begin{tabular}{|c|c|}
\hline Compound class & Species \\
\hline Aldehydes & $\begin{array}{l}\mathrm{HCHO}, \mathrm{CH}_{3} \mathrm{CHO}, \mathrm{HOCH}_{2} \mathrm{CHO}, \mathrm{HC}(\mathrm{O}) \mathrm{C}(\mathrm{O}) \mathrm{H}, \mathrm{CH}_{3} \mathrm{CH}_{2} \mathrm{CHO}, \\
\mathrm{HOCH}_{2} \mathrm{CH}_{2} \mathrm{CHO}, \mathrm{CH}_{2} \mathrm{CH}_{2} \mathrm{CH}_{2} \mathrm{CHO}, \mathrm{HC}(\mathrm{O}) \mathrm{CH}_{2} \mathrm{CHO}, \mathrm{HOCH}_{2} \mathrm{CH}_{2} \mathrm{CH}_{2} \mathrm{CHO}, \\
\mathrm{CH}_{3} \mathrm{C}(\mathrm{O}) \mathrm{C}(\mathrm{O}) \mathrm{CHO}\end{array}$ \\
\hline Alcohols & $\begin{array}{l}\mathrm{CH}_{3} \mathrm{CH}_{2} \mathrm{CH}_{2} \mathrm{CH}_{2} \mathrm{OH}, \mathrm{CH}_{3} \mathrm{CH}(\mathrm{OH}) \mathrm{CH}_{2} \mathrm{CH}_{3}, \mathrm{HOCH}_{2} \mathrm{CH}_{2} \mathrm{CH}_{2} \mathrm{CH}_{2} \mathrm{OH}, \\
\mathrm{CH}_{3} \mathrm{C}(\mathrm{O}) \mathrm{C}(\mathrm{O}) \mathrm{CH}_{2} \mathrm{OH}, \mathrm{CH}_{3} \mathrm{CH}_{2} \mathrm{CH}_{2} \mathrm{OH}, \mathrm{HOCH}_{2} \mathrm{CH}_{2} \mathrm{CH}_{2} \mathrm{OH}, \\
\mathrm{CH}(\mathrm{O}) \mathrm{CH}_{2} \mathrm{CH}_{2} \mathrm{OH}, \mathrm{CH}_{3} \mathrm{CH}_{2} \mathrm{OH}, \mathrm{HOCH}_{2} \mathrm{CH}_{2} \mathrm{OH}, \mathrm{HC}(\mathrm{O}) \mathrm{CH}_{2} \mathrm{OH}, \mathrm{CH}_{3} \mathrm{OH}\end{array}$ \\
\hline Organic nitrates & $\begin{array}{l}\mathrm{CH}_{3} \mathrm{CH}_{2} \mathrm{CH}_{2} \mathrm{CH}_{2} \mathrm{ONO}_{2}, \mathrm{CH}_{3} \mathrm{CH}\left(\mathrm{ONO}_{2}\right) \mathrm{CH}_{2} \mathrm{CH}_{3}, \mathrm{HOCH}_{2} \mathrm{CH}_{2} \mathrm{CH}_{2} \mathrm{CH}_{2} \mathrm{ONO}_{2}, \\
\mathrm{CH}_{3} \mathrm{C}(\mathrm{O}) \mathrm{C}(\mathrm{O}) \mathrm{CH}_{2} \mathrm{ONO}_{2}, \mathrm{CH}_{3} \mathrm{CH}_{2} \mathrm{CH}_{2} \mathrm{ONO}_{2}, \mathrm{HOCH}_{2} \mathrm{CH}_{2} \mathrm{CH}_{2} \mathrm{ONO}_{2}, \\
\mathrm{CH}(\mathrm{O}) \mathrm{CH}_{2} \mathrm{CH}_{2} \mathrm{ONO}_{2}, \mathrm{CH}_{3} \mathrm{CH}_{2} \mathrm{ONO}_{2}, \mathrm{HOCH}_{2} \mathrm{CH}_{2} \mathrm{ONO}_{2}, \mathrm{HC}(\mathrm{O}) \mathrm{CH}_{2} \mathrm{ONO}_{2}, \\
\mathrm{CH}_{3} \mathrm{ONO}_{2}\end{array}$ \\
\hline Peroxyacyl nitrates & $\begin{array}{l}\mathrm{CH}_{3} \mathrm{C}(\mathrm{O}) \mathrm{O}_{2} \mathrm{NO}_{2}, \mathrm{HC}(\mathrm{O}) \mathrm{C}(\mathrm{O}) \mathrm{O}_{2} \mathrm{NO}_{2}, \mathrm{HOCH}_{2} \mathrm{C}(\mathrm{O}) \mathrm{O}_{2} \mathrm{NO}_{2}, \mathrm{CH}_{3} \mathrm{CH}_{2} \mathrm{C}(\mathrm{O}) \mathrm{O}_{2} \mathrm{NO}_{2}, \\
\mathrm{HC}(\mathrm{O}) \mathrm{CH}_{2} \mathrm{C}(\mathrm{O}) \mathrm{O}_{2} \mathrm{NO}_{2}, \mathrm{HOCH}_{2} \mathrm{CH}_{2} \mathrm{C}(\mathrm{O}) \mathrm{O}_{2} \mathrm{NO}_{2}, \mathrm{CH}_{3} \mathrm{CH}_{2} \mathrm{CH}_{2} \mathrm{C}(\mathrm{O}) \mathrm{O}_{2} \mathrm{NO}_{2}, \\
\mathrm{HOCH}_{2} \mathrm{CH}_{2} \mathrm{CH}_{2} \mathrm{C}(\mathrm{O}) \mathrm{O}_{2} \mathrm{NO}_{2}, \mathrm{HC}(\mathrm{O}) \mathrm{CH}_{2} \mathrm{CH}_{2} \mathrm{C}(\mathrm{O}) \mathrm{O}_{2} \mathrm{NO}_{2}\end{array}$ \\
\hline $\begin{array}{l}\text { Carboxylic acids and } \\
\text { percarboxylic acids }\end{array}$ & $\begin{array}{l}\mathrm{CH}_{3} \mathrm{CH}_{2} \mathrm{CH}_{2} \mathrm{C}(\mathrm{O}) \mathrm{OH}, \mathrm{HOCH}_{2} \mathrm{CH}_{2} \mathrm{CH}_{2} \mathrm{C}(\mathrm{O}) \mathrm{OH}, \mathrm{HC}(\mathrm{O}) \mathrm{CH}_{2} \mathrm{CH}_{2} \mathrm{C}(\mathrm{O}) \mathrm{OH}, \\
\mathrm{CH}_{3} \mathrm{CH}_{2} \mathrm{C}(\mathrm{O}) \mathrm{OH}, \mathrm{HOCH} \mathrm{CH}_{2} \mathrm{C}(\mathrm{O}) \mathrm{OH}, \mathrm{CH}_{3} \mathrm{C}(\mathrm{O}) \mathrm{OH}, \mathrm{HOCH}_{2} \mathrm{C}(\mathrm{O}) \mathrm{OH}, \\
\mathrm{HC}(\mathrm{O}) \mathrm{CH}_{2} \mathrm{CO}_{2} \mathrm{H}, \mathrm{HC}(\mathrm{O}) \mathrm{C}(\mathrm{O}) \mathrm{OH}, \mathrm{CH}_{3} \mathrm{CH}_{2} \mathrm{CH}_{2} \mathrm{C}(\mathrm{O}) \mathrm{O}_{2} \mathrm{H}, \\
\mathrm{HOCH}_{2} \mathrm{CH}_{2} \mathrm{CH}_{2} \mathrm{C}(\mathrm{O}) \mathrm{O}_{2} \mathrm{H}, \mathrm{HC}(\mathrm{O}) \mathrm{CH}_{2} \mathrm{CH}_{2} \mathrm{C}(\mathrm{O}) \mathrm{O}_{2} \mathrm{H}, \mathrm{CH}_{3} \mathrm{CH}_{2} \mathrm{C}(\mathrm{O}) \mathrm{O}_{2} \mathrm{H}, \\
\mathrm{HOCH}_{2} \mathrm{CH}_{2} \mathrm{C}(\mathrm{O}) \mathrm{O}_{2} \mathrm{H}, \mathrm{HC}(\mathrm{O}) \mathrm{CH}_{2} \mathrm{C}(\mathrm{O}) \mathrm{O}_{2} \mathrm{H}, \mathrm{CH}_{3} \mathrm{C}(\mathrm{O}) \mathrm{O}_{2} \mathrm{H}, \mathrm{HOCH}_{2} \mathrm{C}(\mathrm{O}) \mathrm{O}_{2} \mathrm{H}, \\
\mathrm{HC}(\mathrm{O}) \mathrm{C}(\mathrm{O}) \mathrm{O}_{2} \mathrm{H}\end{array}$ \\
\hline
\end{tabular}

Peroxy radical chemistry is a central feature of the atmospheric oxidation mechanism of organic compounds. ${ }^{10-11}$ Peroxy radicals are formed by addition of $\mathrm{O}_{2}$ to carbon centered radicals 
produced by hydrogen abstraction from $\mathrm{C}-\mathrm{H}$ bonds by $\mathrm{HO}$ or $\mathrm{NO}_{3}$ radicals, or via addition to $>\mathrm{C}=\mathrm{C}<$ double bonds by $\mathrm{O}_{3}, \mathrm{HO}$, or $\mathrm{NO}_{3}$. Peroxy radicals have the general formula $\mathrm{RO}_{2}$ where $\mathrm{R}$ is an organic moiety (e.g., $\mathrm{CH}_{3}, \mathrm{C}_{2} \mathrm{H}_{5}, \mathrm{CH}_{3} \mathrm{C}(\mathrm{O})$ ), the simplest example is $\mathrm{CH}_{3} \mathrm{O}_{2}$. Peroxy radicals react with $\mathrm{NO}, \mathrm{NO}_{2}$ other organic peroxy radicals, and with $\mathrm{HO}_{2}$ radicals. The reaction with $\mathrm{NO}$ proceeds via two channels giving alkoxy radicals (RO) and $\mathrm{NO}_{2}$ and organic nitrates $\left(\mathrm{RONO}_{2}\right)$. The reaction with other peroxy radicals proceeds via a disproportionation channel and a channel giving alkoxy radicals. The reaction with $\mathrm{NO}_{2}$ is an association reaction and gives peroxynitrates which are typically unstable with respect to thermal decomposition back to reactants. The reaction with $\mathrm{HO}_{2}$ radicals gives organic hydroperoxides (ROOH). These reactions are illustrated for the case of $\mathrm{CH}_{3} \mathrm{O}_{2}$ below ( $\mathrm{M}$ is a third body gas, typically $\mathrm{N}_{2}$ )

$$
\begin{gathered}
\mathrm{CH}_{3} \mathrm{O}_{2}+\mathrm{NO} \rightarrow \mathrm{CH}_{3} \mathrm{O}+\mathrm{NO}_{2} \\
\mathrm{CH}_{3} \mathrm{O}_{2}+\mathrm{NO}+\mathrm{M} \rightarrow \mathrm{CH}_{3} \mathrm{ONO}_{2}+\mathrm{M} \\
\mathrm{CH}_{3} \mathrm{O}_{2}+\mathrm{NO}_{2}+\mathrm{M} \leftrightarrow \mathrm{CH}_{3} \mathrm{O}_{2} \mathrm{NO}_{2}+\mathrm{M} \\
\mathrm{CH}_{3} \mathrm{O}_{2}+\mathrm{CH}_{3} \mathrm{O}_{2} \rightarrow \mathrm{CH}_{3} \mathrm{OH}+\mathrm{HCHO}+\mathrm{O}_{2} \\
\mathrm{CH}_{3} \mathrm{O}_{2}+\mathrm{CH}_{3} \mathrm{O}_{2} \rightarrow \mathrm{CH}_{3} \mathrm{O}+\mathrm{CH}_{3} \mathrm{O}+\mathrm{O}_{2} \\
\mathrm{CH}_{3} \mathrm{O}_{2}+\mathrm{HO}_{2} \rightarrow \mathrm{CH}_{3} \mathrm{OOH}+\mathrm{O}_{2}
\end{gathered}
$$




\subsection{Biogenic OVOC emissions}

Global emissions of $\mathrm{CH}_{4}$ are estimated to be $556 \mathrm{Tg}$ in 2011 (354 $\mathrm{Tg}$ anthropogenic, $202 \mathrm{Tg}$ natural), allowing for a small increase in the atmospheric burden of $\left(14 \mathrm{Tg} \mathrm{yr}^{-1}\right)$, the balance of $542 \mathrm{Tg} \mathrm{yr}^{-1}$ is oxidized and provides a large flux of $\mathrm{HCHO}, \mathrm{CH}_{3} \mathrm{OH}$, and $\mathrm{CH}_{3} \mathrm{OOH}$ into the atmosphere. ${ }^{4}$ Isoprene (2-methyl-1,3-butadiene) is emitted by plants in amounts comparable to the emissions of $\mathrm{CH}_{4}$. The global biogenic emission of isoprene in 2000 is estimated to be 535 $\mathrm{Tg} \mathrm{yr}^{-1} \cdot{ }^{12}$ Under high $\mathrm{NO}_{\mathrm{x}}$ conditions where peroxy radical reactivity is dominated by reaction with $\mathrm{NO}$, the $\mathrm{HO}$ initiated oxidation of isoprene gives methyl vinyl ketone and methacrolein as the major stable products. ${ }^{8}$ Under low- $\mathrm{NO}_{\mathrm{x}}$ conditions isomerization reactions can become important for the peroxy radicals produced from isoprene and a broad variety of oxygenated organic products become important. ${ }^{13-15} \mathrm{CH}_{4}$ and isoprene are by far the highest volume $\mathrm{HC}$ emissions into the global atmosphere. In contrast to the approximately $535 \mathrm{Tg} \mathrm{yr}^{-1}$ biogenic emission of isoprene, the combined global anthropogenic emission of all non-methane VOCs

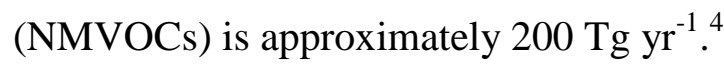

Plants are major emitters of both VOCs and OVOCs. ${ }^{12,16}$ Table 2 gives estimates for the top 15 biogenic emissions. ${ }^{12}$ As seen from Table 2, methanol, acetone, ethanol, and acetaldehyde are emitted in large amounts. Methanol is the largest biogenic OVOC emission at approximately $100 \mathrm{Tg} \mathrm{yr}^{-1}$. 
Table 2: Global biogenic emissions estimated for the year $2000{ }^{12}$

\begin{tabular}{|l|l|l|l|}
\hline Compound & Emission $\left(\mathbf{T g ~ y r}^{-1}\right)$ & Compound & Emission $\left(\mathbf{T g} \mathbf{~ y r}^{-1}\right)$ \\
\hline Isoprene & 535 & $\beta$-Pinene & 18.9 \\
\hline Methanol & 99.6 & Propene & 15.8 \\
\hline$\alpha$-Pinene & 66.1 & Limonene & 11.4 \\
\hline Acetone & 43.7 & Sabinene & 9.0 \\
\hline Ethene & 26.9 & Myrcene & 8.7 \\
\hline Ethanol & 20.7 & Butene & 8.0 \\
\hline Acetaldehyde & 20.7 & $\beta$-Caryophyllene & 7.4 \\
\hline t- $\beta$-Ocimene & 19.4 & Total VOC + OVOC & 1007 \\
\hline
\end{tabular}

For perspective the global industrial production of methanol in 2012 was $65 \mathrm{Tg}^{17}$ and emissions

from industrial sources are a small fraction of production. Methanol and acetone are by-products

and acetaldehyde is an intermediate of plant metabolism and escape into the atmosphere ${ }^{16}$ from

plant leaves and stems. In conditions where there is insufficient oxygen (e.g., when roots are

flooded), plants maintain energy production by switching from aerobic respiration to

fermentation $^{18-19}$. Fermentation produces ethanol, much of which is metabolized within the

plant, but some escapes into the atmosphere. ${ }^{20-21}$ 


\subsection{Anthropogenic OVOC emissions}

Oxygenates are used extensively as fuels, fuel additives, solvents, and feedstocks for the chemical industry. The use of oxygenates in blends with gasoline serves three main purposes. First, oxygenates such as ethanol, ethyl tert-butyl ether (ETBE), methyl tert-butyl ether (MTBE), and tert-amyl methyl ether (TAME), improve the antiknock quality (increase octane number) of fuel by resisting autoignition. Following the removal of tetraethyl lead from gasoline in the late 1970s, oxygenates such as MTBE found widespread use as blending components to boost the octane number of gasoline. Concerns regarding ground water contamination lead to the phase out of MTBE use in the U.S. in the 2000s. Second, by physically displacing or diluting some of the fuel components (e.g., aromatics), the presence of oxygenates helps to reduce certain harmful tailpipe emissions (e.g., benzene). Third, oxygenates derived from renewable sources such as ethanol from corn, sugar cane, and cellulose and fatty acid methyl esters from animal fats and vegetable oils displace petroleum and can improve energy security and reduce greenhouse gas emissions. As seen from Figures 1 and 2 there has been a large increase in the use of ethanol in fuel in the U.S. and globally over the past $10-15$ years. ${ }^{22}$ Annual global ethanol fuel production is currently approximately 85 billion liters $(67 \mathrm{Tg})$. Ethanol is also produced in large quantities

for consumption in alcoholic beverages. Global beer production is approximately $1.9 \times 10^{11}$ liters $^{23}$ and wine production is approximately $2.7 \times 10^{10}$ liters. $^{24}$ Making the assumption that 
beer and wine have ethanol contents of 5\% and 12\%, respectively, gives an estimate of 13 billion liters $(10 \mathrm{Tg})$ of ethanol production in the beverage industry. Approximately $9 \mathrm{Tg}_{\mathrm{yr}}{ }^{-1}$ of ethanol is used in commercial and industrial solvents. ${ }^{25}$ The anthropogenic emissions of ethanol are

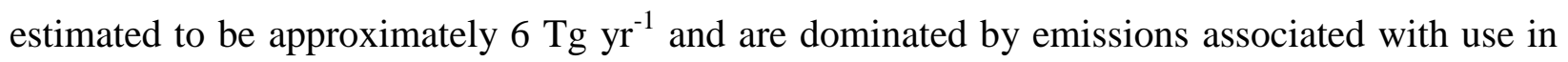
commercial and industrial solvents. ${ }^{25}$

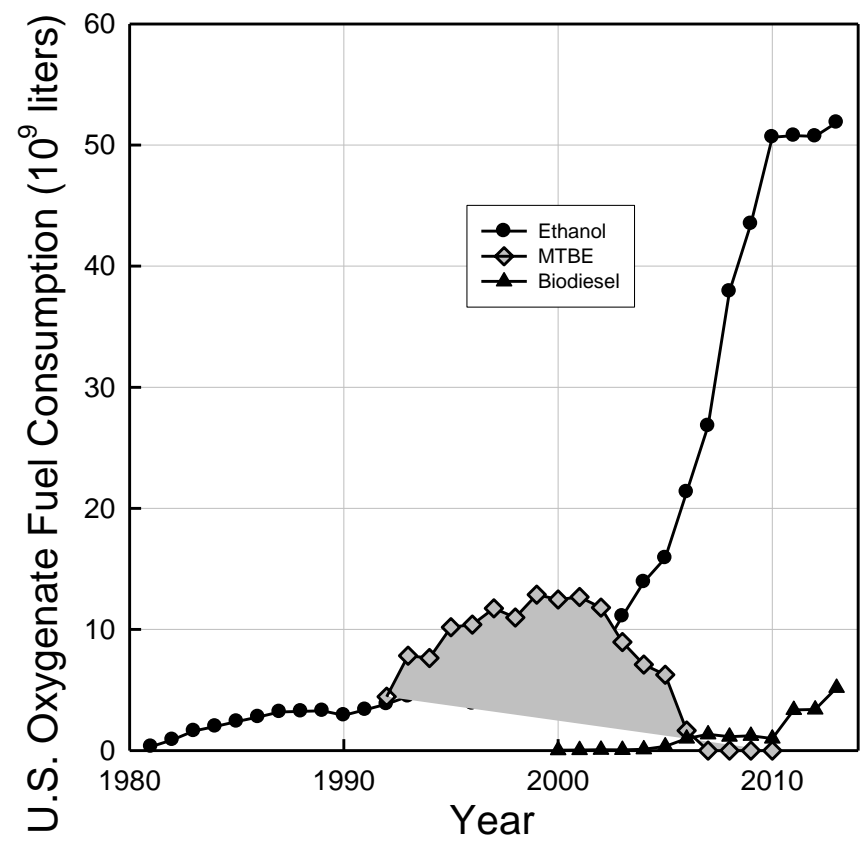

Figure 1. U.S. oxygenate transportation fuel use (USDOE, 2014) ${ }^{26}$ 


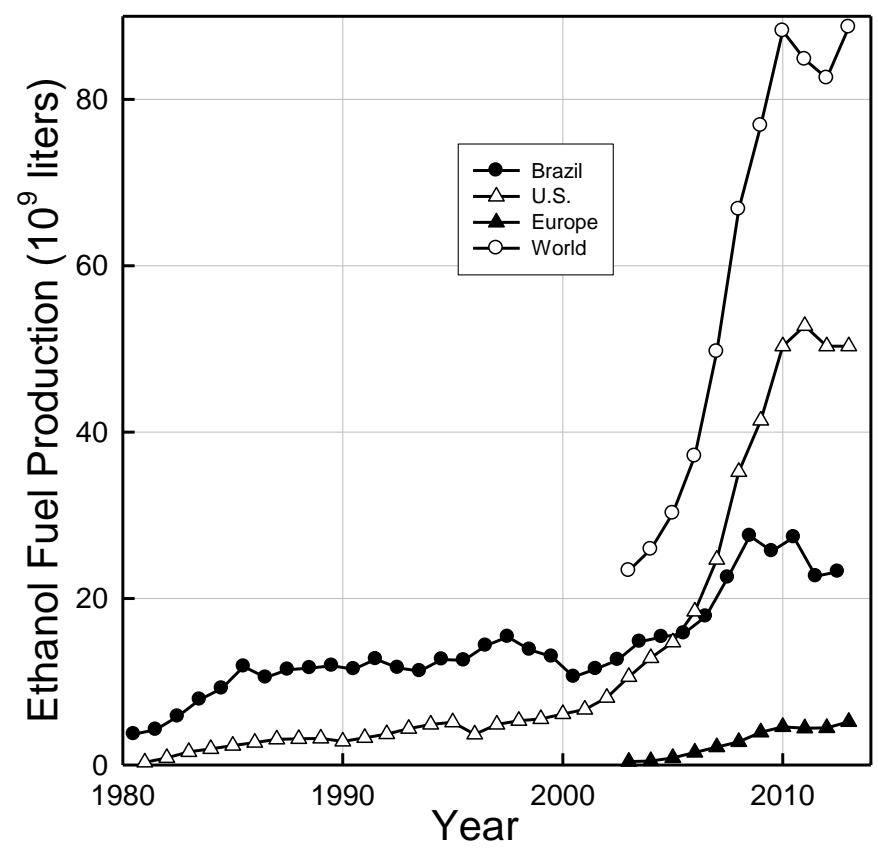

Figure 2. Global ethanol transportation fuel use 8,26

Methanol is used as an additive to gasoline. Dimethyl ether is used as a diesel fuel. As illustrated in Figures 3 and 4, methanol and dimethyl ether are finding increased use as transportation fuels, however the absolute use of these fuels is still small compared to the approximately $8 \times 10^{10}$ liters of ethanol and very small compared to the approximately $3 \times 10^{12}$ liters of petroleum derived fuel used annually in global transportation. Table 3 shows a listing of the top 20 by mass anthropogenic VOC and OVOC emissions in 2010 in the U.K.; ${ }^{27}$ emissions of ethanol and methanol feature highly in both lists. The total emissions in the U.K. in 2010 of anthropogenic VOCs and OVOCs were approximately 540 and 260 ktonnes, respectively. These 
emissions were substantially greater than the estimated biogenic VOC (isoprene, monoterpenes, and sesquiterpenes) and biogenic OVOC (methanol, ethanol, acetaldehyde, acetone, and others) emissions of 115-172 and 106-123 and ktonnes $\mathrm{yr}^{-1}$, respectively, in the U.K. in $2006{ }^{28}$

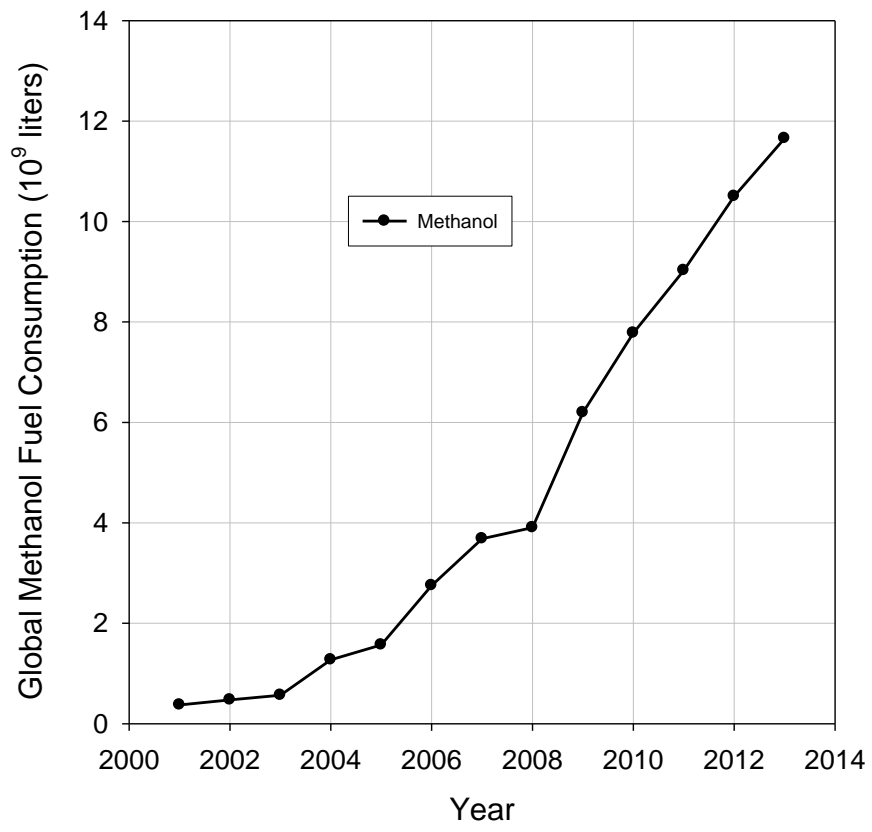

Figure 3. Global methanol transportation fuel use (Methanol Institute, 2014). ${ }^{29}$ 


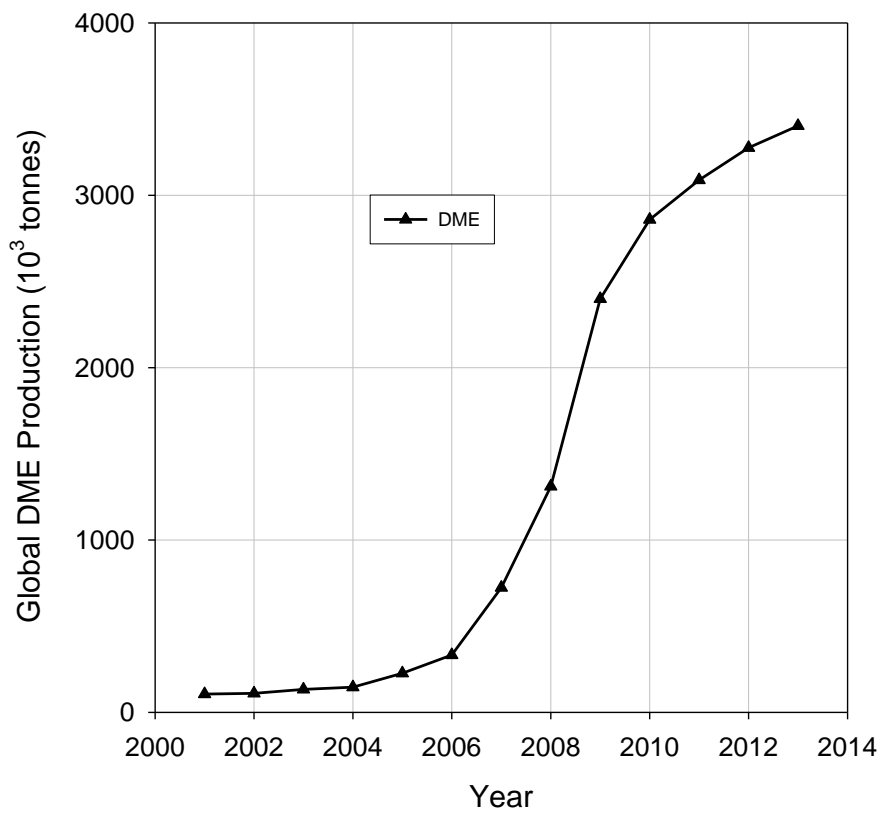

Figure 4. Global dimethyl ether transportation fuel use (Methanol Institute, 2014). ${ }^{29}$

Table 3: Top 20 VOC and OVOC (by mass) emissions from anthropogenic sources in the U.K. in $2010 .^{30}$

\begin{tabular}{|c|c|c|c|c|c|}
\hline \multicolumn{3}{|c|}{ VOC } & \multicolumn{3}{|c|}{ OVOC } \\
\hline Species & $\begin{array}{c}\text { Total } \\
\text { emissions } \\
\text { ktonnes yr-1 }\end{array}$ & $\begin{array}{l}\text { Fraction of } \\
\text { the total } \\
\text { emissions }\end{array}$ & Species & $\begin{array}{c}\text { Total } \\
\text { emissions } \\
\text { ktonnes } \mathbf{y r}^{-1}\end{array}$ & $\begin{array}{c}\text { Fraction of } \\
\text { the total } \\
\text { emissions }\end{array}$ \\
\hline ethanol & 103.80 & 0.194 & ethanol & 103.80 & 0.407 \\
\hline butane & 54.09 & 0.101 & methanol & 30.42 & 0.119 \\
\hline ethane & 37.62 & 0.070 & acetone & 19.15 & 0.075 \\
\hline methanol & 30.42 & 0.057 & formaldehyde & 11.37 & 0.045 \\
\hline propane & 26.50 & 0.050 & 2-butanone & 10.80 & 0.042 \\
\hline
\end{tabular}




\begin{tabular}{|l|l|l|l|l|l|}
\hline toluene & 20.62 & 0.039 & 2-propanol & 7.99 & 0.031 \\
\hline acetone & 19.15 & 0.036 & butyl acetate & 7.66 & 0.030 \\
\hline ethylene & 15.01 & 0.028 & ethyl acetate & 7.13 & 0.028 \\
\hline 2-methylbutane & 13.91 & 0.026 & 4-methyl-2-pentanone & 5.62 & 0.022 \\
\hline pentane & 13.71 & 0.026 & 1-propanol & 3.52 & 0.014 \\
\hline m-xylene & 13.25 & 0.025 & 2-butoxyethanol & 3.22 & 0.013 \\
\hline trichloroethene & 12.72 & 0.024 & 1-butanol & 3.21 & 0.013 \\
\hline hexane & 12.22 & 0.023 & acetaldehyde & 2.93 & 0.012 \\
\hline formaldehyde & 11.37 & 0.021 & 1-methoxy-2-propanol & 2.22 & 0.009 \\
\hline dichloromethane & 11.32 & 0.021 & methyl acetate & 1.93 & 0.008 \\
\hline 2-butanone & 10.80 & 0.020 & furfural & 1.88 & 0.007 \\
\hline 2-methylpropane & 10.49 & 0.020 & 1-methoxy-2-propyl acetate & 1.71 & 0.007 \\
\hline benzene & 9.34 & 0.017 & dimethyl ether & 1.70 & 0.007 \\
\hline 2-propanol & 7.99 & 0.015 & 2-(2-butoxyethoxy)ethanol & 1.43 & 0.006 \\
\hline decane & 7.98 & 0.015 & 2-(2-ethoxyethoxy)ethanol & 1.34 & 0.005 \\
\hline
\end{tabular}

The increasing ethanol content in gasoline has led to interest in the impact of ethanol on vehicle emissions. The single largest VOC emission from engines is unburned fuel. Modern internal combustion engines combust approximately 97-99\% of the fuel to $\mathrm{CO}_{2}$ and $\mathrm{H}_{2} \mathrm{O}$ leaving approximately $1-3 \%$ unburned or partial burned fuel in the engine-out exhaust. ${ }^{31}$ Vehicles are equipped with emission control systems which remove approximately $95-99 \%$ of the organic compounds in the exhaust. Figure 5 shows a plot of emissions versus fuel ethanol content for 
tests of a typical flexible fuel vehicle (FFV). ${ }^{32}$ The emission trends in Figure 5 can be explained by two different factors: fuel chemistry and engine calibration. ${ }^{32}$ As the ethanol content increases fuel chemistry considerations dictate that the emissions of ethanol and its oxidation products (e.g., acetaldehyde) will increase and emissions of gasoline components (e.g., benzene, aromatics) will decrease. Fuel chemistry effects are fundamental in nature; the same trend of increased ethanol, acetaldehyde, formaldehyde, and $\mathrm{CH}_{4}$ emissions (formed by decomposition of $\mathrm{CH}_{3} \mathrm{CHO}$ into $\mathrm{CH}_{4}$ and $\mathrm{CO}$ by $\mathrm{Rh}$ catalysts ${ }^{32}$ ) and decreased non-methane hydrocarbons (NMHC) and benzene emissions are expected for all FFVs. Engine calibration effects refer to how the operation of the engine is modified as the vehicle senses changes in ethanol content of the fuel. Engine calibration determines how emission trends for $\mathrm{NO}_{\mathrm{x}}$ and total hydrocarbons depend on the ethanol fuel content. Engine calibration are manufacturer and model specific and trends of $\mathrm{NO}_{\mathrm{x}}$ and total hydrocarbons emissions will not be the same for all FFVs. ${ }^{32}$ 


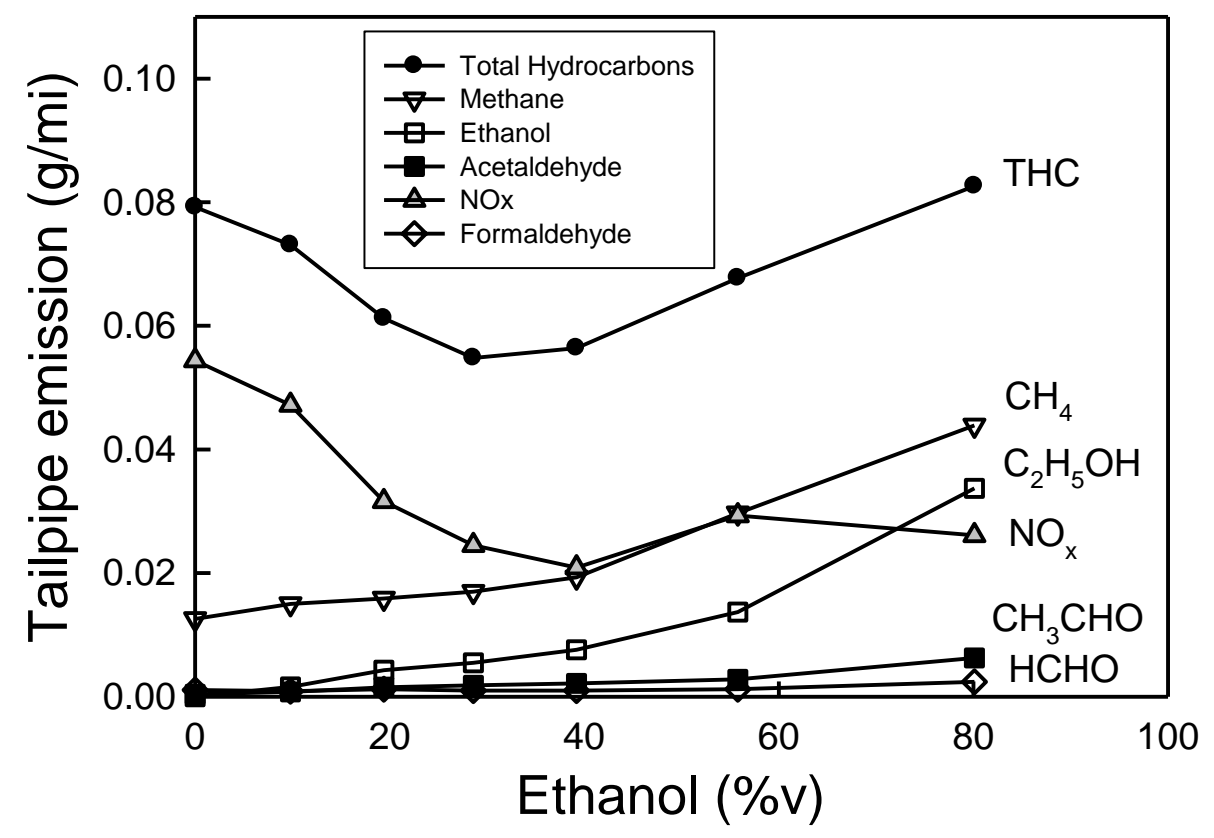

Figure 5. Federal test procedure cycle-weighted tailpipe emissions of total hydrocarbons (THC), methane, ethanol, $\mathrm{NO}_{\mathrm{x}}$, acetaldehyde, and formaldehyde versus fuel ethanol concentration. ${ }^{32}$

\subsection{Background OVOC atmospheric concentrations}

Figure 6 shows the observed distribution of OVOCs in the remote Pacific troposphere. ${ }^{33}$

It is well established that OVOCs are important trace species in the global atmosphere. ${ }^{33-35}$ Methanol is the most abundant OVOC in the atmosphere followed either by $\mathrm{CH}_{3} \mathrm{OOH}$ or acetone, depending on location. While $\mathrm{HCHO}$ is the fourth most abundant OVOC, its short 
atmospheric lifetime (order of hours) implies a much larger flux than for methanol the most abundant OVOC which has much longer atmospheric lifetime (order of weeks). $\mathrm{HCHO}$ is one of the most reactive and most important OVOCs in tropospheric photochemistry.
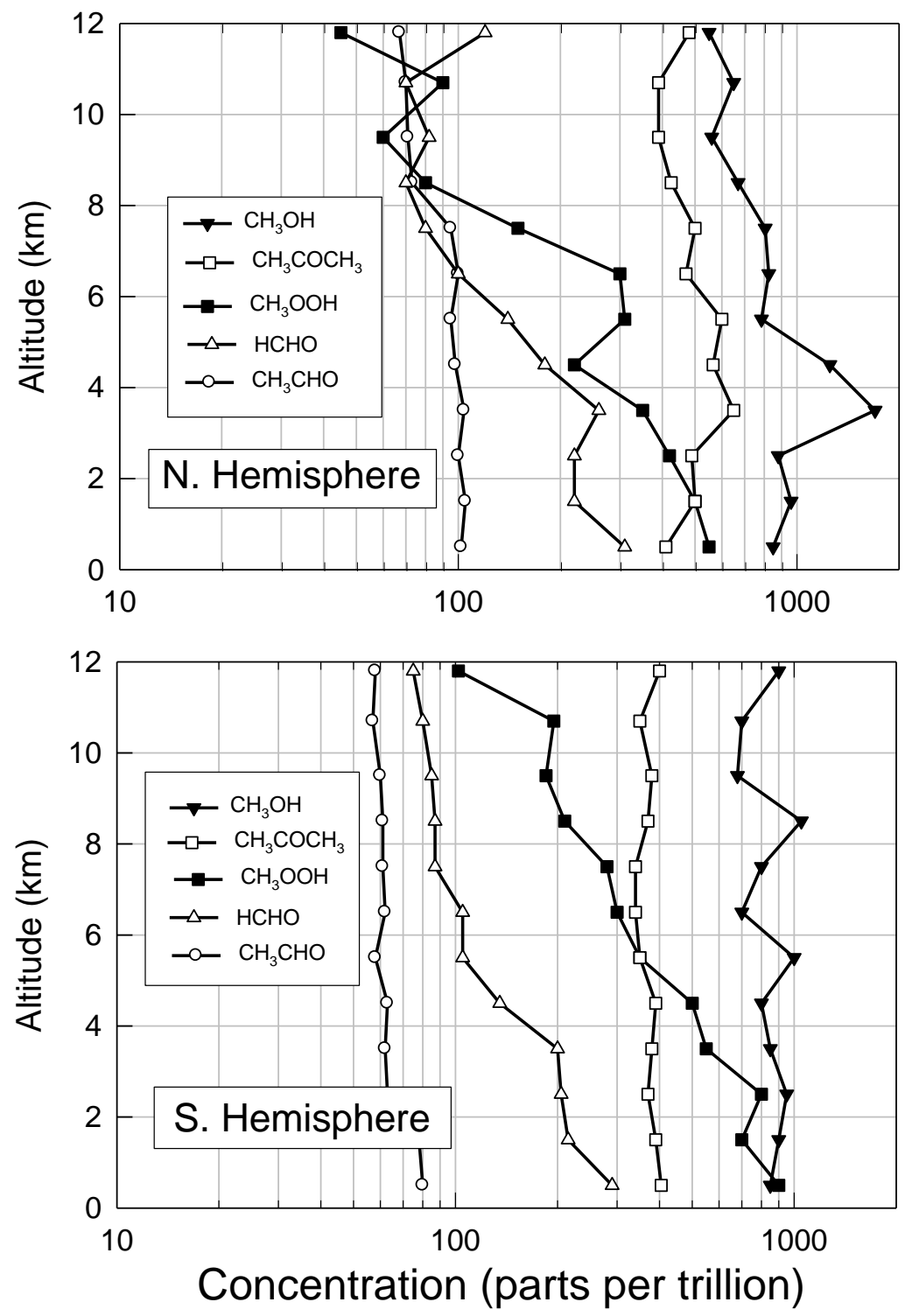

Figure 6. Representative concentration profiles for the five most abundant OVOCs in the Northern and Southern Hemispheres adapted from Singh et al. ${ }^{33}$ 


\section{$3 \quad$ Atmospheric Chemistry of OVOCs}

In the atmosphere, oxygenated volatile organic compounds from both anthropogenic and biogenic sources undergo various chemical and physical processes leading to their transformation or removal from the atmosphere. Removal of OVOCs occurs through photolysis and by wet and/or dry deposition. Most OVOCs have low Henry's law constants, below $10^{3} \mathrm{M}$ $\mathrm{atm}^{-1},{ }^{36}$ indicating that they will partition into the gas phase. ${ }^{8}$ For example, ketones, aldehydes others than formaldehyde, esters and ethers are relatively insoluble in water while alcohols have some solubility especially those with short aliphatic chains. Incorporation into water for the nonsoluble OVOCs will not be of importance in the atmosphere. The highly oxidised OVOCs such as polyols are extremely water soluble, and wet and dry deposition are important for these species. Wet and dry deposition are important loss mechanisms for the smaller carboxylic acids in the troposphere.

The OVOCs have lower vapor pressures than the corresponding alkanes. For compounds with the same number of carbon atoms, the general trend in vapor pressures is alkanes > ethers > aldehydes $\approx$ esters $>$ alcohols $>$ carboxylic acids. For molecules with a given number of carbons, the vapor pressure decreases dramatically with addition of oxygen atoms and increasing oxidation of the molecule as illustrated in Figure $7 .{ }^{8}$ Low volatility multifunctional oxygenated organic compounds condense onto existing atmospheric particles and hence increase the organic 
fraction content of secondary organic aerosols. The contribution of OVOC oxidation to SOA formation is of interest with respect to its potential impacts on air quality, human health, and climate.

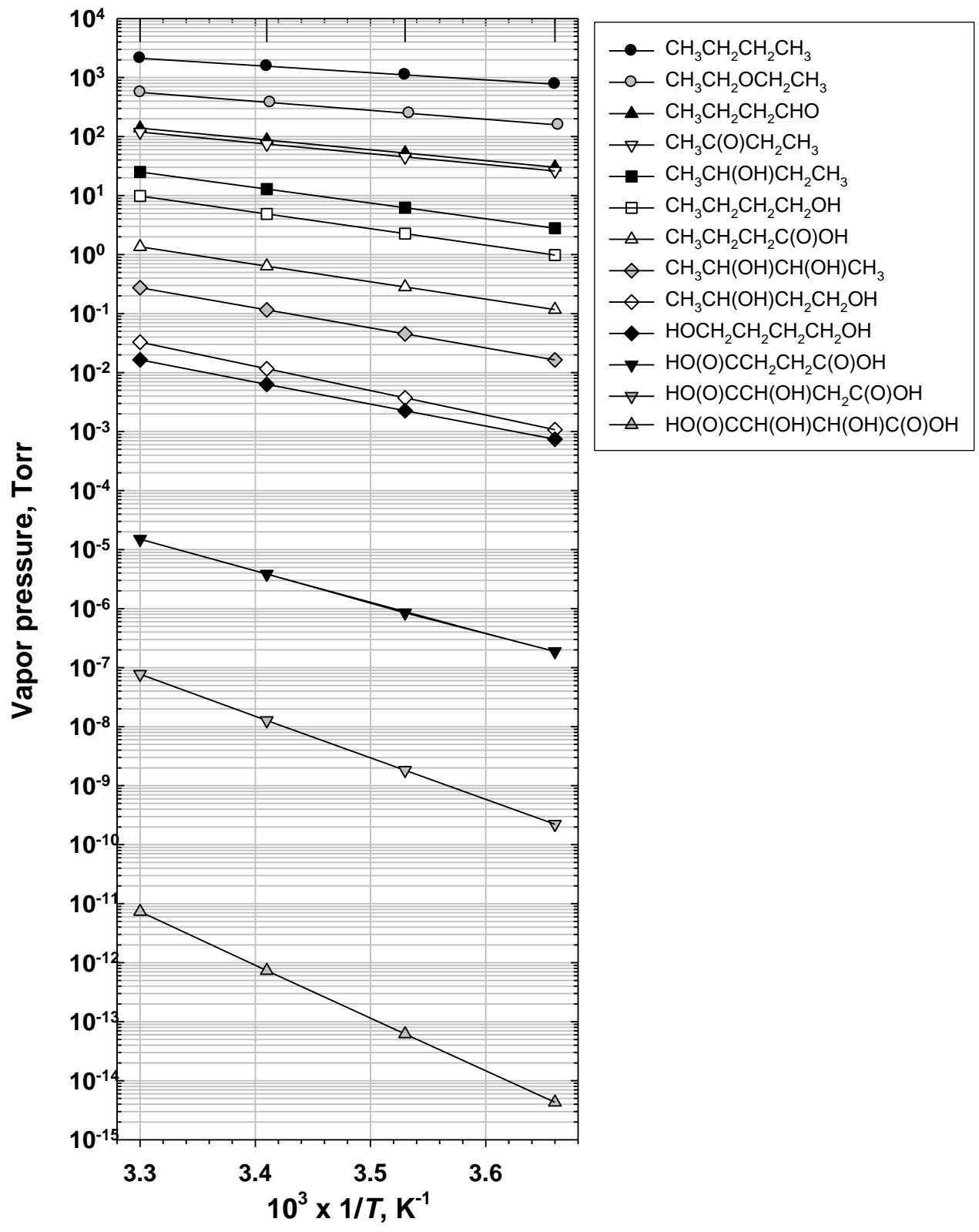


Figure 7. Semilog plot of vapor pressure vs reciprocal temperature for butane and its oxygenated derivatives adapted from Calvert et al. ${ }^{8}$

The majority of OVOCs are oxidised in the atmosphere through chemical reactions in the gas phase $^{8-9}$. The degradation of saturated oxygenated volatile organic compounds is largely initiated by their reaction with hydroxyl radicals $(\mathrm{OH})$. In addition, photolysis of carbonyls such as aldehydes and ketones can also play a significant role in their atmospheric degradation. The oxidation of unsaturated oxygenated compounds may be initiated by reaction with ozone, nitrate $\left(\mathrm{NO}_{3}\right)$ and hydroxyl radicals. The kinetics and mechanisms for these reactions have been comprehensively reviewed $^{8-9}$. OH radicals are formed following the photolysis of ozone and hence their concentration is significant during the day, but very low at night. In contrast, $\mathrm{NO}_{3}$ radicals are photolyzed rapidly so their concentration during the day is very low, but can be significant at night. $\mathrm{OH}$ radical initiated oxidation of OVOCs is important during the day while $\mathrm{NO}_{3}$ radical initiated oxidation can be important at night and depends on the reactivity of the OVOC towards $\mathrm{NO}_{3}$ radicals and the local conditions. Chlorine atoms react rapidly with OVOCs $^{8,37}$ however the concentration of chlorine atoms in the troposphere is generally very low and hence reaction with chlorine atoms is not a major fate of OVOCs. The degradation of OVOCs in the troposphere leads to the production of a large range of secondary pollutants such 
as ozone, highly oxidised VOCs (HOVOCs), peroxyacyl nitrates, and secondary organic aerosols (SOA). Hence, the oxygenated compounds play an important role in determining the oxidizing capacity of the troposphere both on a regional and a global scale. Ozone is a greenhouse gas and at high concentrations it is known to have adverse effects on human health and ecosystems. Understanding the contribution of various OVOCs to ozone formation is of particular interest. Indeed, the control strategies of the OVOCs emissions into the atmosphere are mostly based on their individual contribution to photochemical ozone formation. ${ }^{38}$

In addition to local air quality issues it is important to consider the potential direct and indirect effects of OVOCs on climate change. In terms of potential direct effects the ability of OVOCs to contribute to radiative forcing of climate is dependent on their atmospheric lifetimes and the intensity and position of their IR absorption bands. With the exception of a few halogenated OVOCs discussed in a following section, the atmospheric lifetimes of OVOCs are relatively short (typically in the range of hours to weeks) and their IR absorption is relatively weak. As a consequence, with the exception of a few halogenated ethers, OVOCs have essentially no direct effect on climate.

Changes in the oxidizing capacity of the troposphere both on a regional and a global scale due to the chemistry of the OVOCs may constitute an indirect contribution of these species to radiative forcing. The atmospheric degradation of OVOCs leads to the formation of radicals 
which may in turn affect the atmospheric lifetime of known GHGs such as methane and halogenated VOCs and hence their atmospheric concentrations. The tropospheric ozone concentration is ultimately linked to the chemistry of VOCs and NOx. The atmospheric chemistry of OVOCs impacts the ozone concentration and impacts the contribution of ozone to radiative forcing. The chemical processes leading to the atmospheric degradation of OVOCs and formation of intermediates or end products which contribute to radiative forcing of climate change are the subject of this article. Where atmospheric lifetimes and atmospheric degradation products of OVOCs are given we stress that these are typical lifetimes. Lifetimes and product distributions will vary with local conditions.

\section{Kinetics and Mechanisms of atmospheric degradation of OVOCs}

\subsection{Alcohols}

Alcohols are an important class of oxygenated volatile organic compounds; their presence in ambient air is due to both natural and anthropogenic sources. They are emitted by grassland and agricultural vegetation and have long been used as industrial solvents and motor vehicle fuels and fuel additives. 
Aliphatic alcohols, diols, cyclic and aromatic alcohols: In the atmosphere, aliphatic alcohols are mostly oxidised through their reaction with $\mathrm{OH}$ and $\mathrm{NO}_{3}$ radicals, with the $\mathrm{OH}$ radical reaction being the dominant. Reactions with $\mathrm{O}_{3}$ and photolysis are negligible loss processes. The smaller alcohols are highly water soluble but are also highly volatile and tend to partition into the gasphase. The Henry's law constants values for methanol and ethanol are 220 and $200 \mathrm{M} \mathrm{atm}^{-1}$, respectively. ${ }^{39-40}$ Dry and wet deposition contributes significantly the removal of these smaller alcohols from the atmosphere. For methanol it has been estimated that dry and wet deposition account for about $30 \%$ and $7 \%$ of its atmospheric removal. The rate constants at $298 \mathrm{~K}$ for reactions of $\mathrm{OH}$ with linear straight-chain alcohols increase with the alkyl chain length from $0.9 \times 10^{-12}$ for methanol to $1.3 \times 10^{-11} \mathrm{~cm}^{3}$ molecule $\mathrm{s}^{-1} \mathrm{~s}^{-1}$ for $n$-octanol. ${ }^{8,41}$ The reactivities of the branched alcohols with $\mathrm{OH}$ also fall in this range. The tropospheric lifetimes of the aliphatic alcohols can be estimated by combining their reactivity towards $\mathrm{OH}$ radicals with a diurnal average $[\mathrm{OH}]=10^{6}$ molecule $\mathrm{cm}^{-3}$ to give a range of two weeks for methanol (the least reactive alcohol) to less than a day for more reactive alcohols such as $n$-octanol. The lifetimes of alcohols (see Table 4) are too short for them to make a significant contribution to radiative forcing of climate change. 
Table 4: Kinetic data and estimated atmospheric lifetimes for alcohols with respect to gas-phase reactions with $\mathrm{OH}_{3} \mathrm{O}_{3}$, and $\mathrm{NO}_{3}$.

\begin{tabular}{|c|c|c|c|c|c|c|c|}
\hline Compound & $k_{\mathrm{OH}}\left(\times 10^{-12}\right)^{\mathrm{a}}$ & $\tau_{\mathrm{OH}}{ }^{b}$ & $k_{\mathrm{O} 3}\left(\times 10^{-17}\right)^{\mathrm{a}}$ & $\tau_{\mathrm{O} 3}{ }^{b}$ & $k_{\mathrm{NO} 3}\left(\times 10^{-13}\right)^{\mathrm{a}}$ & $\tau_{\mathrm{NO} 3}{ }^{b, \mathrm{c}}$ & $\tau$ (total lifetime) \\
\hline \multicolumn{8}{|l|}{ Acyclic and Cyclic Alcohols } \\
\hline $\mathrm{CH}_{3} \mathrm{OH}^{\mathrm{d}}$ & 0.9 & $12.9 \mathrm{~d}$ & - & - & 0.0013 & $60 \mathrm{~d}$ & $10.6 \mathrm{~d}$ \\
\hline $\mathrm{C}_{2} \mathrm{H}_{5} \mathrm{OH}^{\mathrm{d}}$ & 3.2 & $3.6 \mathrm{~d}$ & - & - & $<0.02$ & $>4 \mathrm{~d}$ & $3.6 \mathrm{~d}$ \\
\hline$n-\mathrm{C}_{3} \mathrm{H}_{7} \mathrm{OH}$ & 5.7 & $2 \mathrm{~d}$ & - & - & $<0.021$ & $>4 \mathrm{~d}$ & $2.0 \mathrm{~d}$ \\
\hline $\mathrm{CH}_{3} \mathrm{CH}(\mathrm{OH}) \mathrm{CH}_{3}$ & 5.1 & $2.3 \mathrm{~d}$ & - & - & 0.014 & $6 \mathrm{~d}$ & $1.7 \mathrm{~d}$ \\
\hline$n-\mathrm{C}_{4} \mathrm{H}_{9} \mathrm{OH}$ & 8.2 & $1.4 \mathrm{~d}$ & - & - & $<0.028$ & $>3 \mathrm{~d}$ & $1.4 \mathrm{~d}$ \\
\hline$\left(\mathrm{CH}_{3}\right)_{2} \mathrm{CHCH}_{2} \mathrm{OH}$ & 9.6 & $1.2 \mathrm{~d}$ & - & - & - & - & $1.2 \mathrm{~d}$ \\
\hline $\mathrm{CH}_{3} \mathrm{CH}_{2} \mathrm{CH}(\mathrm{OH}) \mathrm{CH}_{3}$ & 8.3 & $1.4 \mathrm{~d}$ & - & - & 0.02 & $4 \mathrm{~d}$ & $1.0 \mathrm{~d}$ \\
\hline$\left(\mathrm{CH}_{3}\right)_{3} \mathrm{COH}$ & 1.1 & $10.5 \mathrm{~d}$ & - & - & - & - & $10.5 \mathrm{~d}$ \\
\hline$\left(\mathrm{CH}_{3}\right)_{3} \mathrm{CCH}_{2} \mathrm{OH}$ & 5.5 & $2.1 \mathrm{~d}$ & - & - & - & - & $2.1 \mathrm{~d}$ \\
\hline $\mathrm{CH}_{3}\left(\mathrm{CH}_{2}\right)_{3} \mathrm{CH}_{2} \mathrm{OH}$ & 11 & $1.05 \mathrm{~d}$ & - & - & - & - & $1.05 \mathrm{~d}$ \\
\hline $\mathrm{CH}_{3} \mathrm{CH}(\mathrm{OH}) \mathrm{CH}_{2} \mathrm{CH}_{2} \mathrm{CH}_{3}$ & 11 & $1.05 \mathrm{~d}$ & - & - & - & - & $1.05 \mathrm{~d}$ \\
\hline $\mathrm{CH}_{3} \mathrm{CH}_{2} \mathrm{CH}(\mathrm{OH}) \mathrm{CH}_{2} \mathrm{CH}_{3}$ & 13 & $8.6 \mathrm{~h}$ & - & - & - & - & $8.6 \mathrm{~h}$ \\
\hline $\mathrm{CH}_{3} \mathrm{CH}\left(\mathrm{CH}_{3}\right) \mathrm{CH}_{2} \mathrm{CH}_{2} \mathrm{OH}$ & 14 & $7.9 \mathrm{~h}$ & - & - & - & - & $7.9 \mathrm{~h}$ \\
\hline$\left(\mathrm{CH}_{3}\right)_{2} \mathrm{C}(\mathrm{OH}) \mathrm{CH}_{2} \mathrm{CH}_{3}$ & 3.2 & $3.6 \mathrm{~d}$ & - & - & - & - & $3.6 \mathrm{~d}$ \\
\hline
\end{tabular}




\begin{tabular}{|c|c|c|c|c|c|c|c|}
\hline $\mathrm{CH}_{3} \mathrm{CH}(\mathrm{OH}) \mathrm{CH}\left(\mathrm{CH}_{3}\right)_{2}$ & 12 & $9.3 \mathrm{~h}$ & - & - & - & - & $9.3 \mathrm{~h}$ \\
\hline$\left(\mathrm{CH}_{3}\right)_{2} \mathrm{CHCH}_{2} \mathrm{CH}_{2} \mathrm{OH}$ & 14 & $7.9 \mathrm{~h}$ & - & - & - & - & $7.9 \mathrm{~h}$ \\
\hline $\mathrm{CH}_{3}\left(\mathrm{CH}_{2}\right)_{4} \mathrm{CH}_{2} \mathrm{OH}$ & 13 & $8.6 \mathrm{~h}$ & - & - & - & - & $8.6 \mathrm{~h}$ \\
\hline $\mathrm{CH}_{3} \mathrm{CH}(\mathrm{OH}) \mathrm{CH}_{2}\left(\mathrm{CH}_{2}\right)_{2} \mathrm{CH}_{3}$ & 12 & $9.3 \mathrm{~h}$ & - & - & - & - & $9.3 \mathrm{~h}$ \\
\hline$\left(\mathrm{CH}_{3}\right)_{2} \mathrm{C}(\mathrm{OH}) \mathrm{CH}_{2} \mathrm{CH}_{2} \mathrm{CH}_{3}$ & 7.1 & $1.6 \mathrm{~d}$ & - & - & - & - & $1.6 \mathrm{~d}$ \\
\hline $\mathrm{CH}_{3} \mathrm{CH}(\mathrm{OH}) \mathrm{CH}_{2} \mathrm{CH}\left(\mathrm{CH}_{3}\right)_{2}$ & 17 & $6.5 \mathrm{~h}$ & - & - & - & - & $6.5 \mathrm{~h}$ \\
\hline$\left(\mathrm{CH}_{3}\right)_{2} \mathrm{C}(\mathrm{OH}) \mathrm{CH}\left(\mathrm{CH}_{3}\right)_{2}$ & 9.3 & $1.3 \mathrm{~d}$ & - & - & - & - & $1.3 \mathrm{~d}$ \\
\hline $\mathrm{n}-\mathrm{C}_{7} \mathrm{H}_{15} \mathrm{OH}$ & 13 & $8.6 \mathrm{~h}$ & - & - & - & - & $8.6 \mathrm{~h}$ \\
\hline $\mathrm{CH}_{3}\left(\mathrm{CH}_{2}\right)_{2} \mathrm{CH}(\mathrm{OH})\left(\mathrm{CH}_{2}\right)_{2} \mathrm{CH}_{3}$ & $17 *$ & $6.5 \mathrm{~h}$ & - & - & $<0.062$ & $>1 \mathrm{~d}$ & $6.5 \mathrm{~h}$ \\
\hline$\left(\mathrm{CH}_{3}\right)_{2} \mathrm{C}(\mathrm{OH}) \mathrm{CH}_{2} \mathrm{CH}\left(\mathrm{CH}_{3}\right)_{2}$ & 11 & $1.05 \mathrm{~d}$ & - & - & - & - & $1.05 \mathrm{~d}$ \\
\hline $\mathrm{n}-\mathrm{C}_{8} \mathrm{H}_{17} \mathrm{OH}$ & 13 & $8.6 \mathrm{~h}$ & - & - & - & - & $8.6 \mathrm{~h}$ \\
\hline $\mathrm{CH}_{3} \mathrm{CH}_{2} \mathrm{C}\left(\mathrm{CH}_{3}\right)(\mathrm{OH}) \mathrm{CH}_{2} \mathrm{CH}\left(\mathrm{CH}_{3}\right)_{2}$ & 13 & $8.6 \mathrm{~h}$ & - & - & - & - & $8.6 \mathrm{~h}$ \\
\hline cyclo- $\mathrm{C}_{5} \mathrm{H}_{9} \mathrm{OH}$ & 11 & $1.05 \mathrm{~d}$ & - & - & - & & $1.05 \mathrm{~d}$ \\
\hline cyclo- $\mathrm{C}_{6} \mathrm{H}_{11} \mathrm{OH}$ & 17 & $6.5 \mathrm{~h}$ & - & - & - & & $6.5 \mathrm{~h}$ \\
\hline \multicolumn{8}{|l|}{ Diols } \\
\hline $\mathrm{HOCH}_{2} \mathrm{CH}_{2} \mathrm{OH}$ & 15 & $7.4 \mathrm{~h}$ & - & - & - & - & $7.4 \mathrm{~h}$ \\
\hline $\mathrm{HOCH}_{2} \mathrm{CH}(\mathrm{OH}) \mathrm{CH}_{3}$ & 21 & $5.3 \mathrm{~h}$ & - & - & - & - & $5.3 \mathrm{~h}$ \\
\hline $\mathrm{HOCH}_{2} \mathrm{CH}(\mathrm{OH}) \mathrm{CH}_{2} \mathrm{CH}_{3}$ & 24 & $4.6 \mathrm{~h}$ & & & & & $4.6 \mathrm{~h}$ \\
\hline $\mathrm{HOCH}_{2} \mathrm{CH}_{2} \mathrm{CH}(\mathrm{OH}) \mathrm{CH}_{3}$ & 30 & $3.7 \mathrm{~h}$ & - & - & - & & $3.7 \mathrm{~h}$ \\
\hline
\end{tabular}




\begin{tabular}{|c|c|c|c|c|c|c|c|}
\hline $\mathrm{CH}_{3} \mathrm{CH}(\mathrm{OH}) \mathrm{CH}(\mathrm{OH}) \mathrm{CH}_{3}$ & 21 & $5.3 \mathrm{~d}$ & - & - & - & & $5.3 \mathrm{~d}$ \\
\hline$\left(\mathrm{CH}_{3}\right)_{2} \mathrm{C}(\mathrm{OH}) \mathrm{CH}_{2} \mathrm{CH}(\mathrm{OH}) \mathrm{CH}_{3}$ & 20 & $5.6 \mathrm{~h}$ & - & - & - & - & $5.6 \mathrm{~h}$ \\
\hline \multicolumn{8}{|l|}{ Unsaturated Alcohols } \\
\hline $\mathrm{CH}_{2} \mathrm{CHCH}_{2} \mathrm{OH}$ & 50 & $2.2 \mathrm{~h}$ & 1.6 & $17.4 \mathrm{~h}$ & 0.13 & $7.1 \mathrm{~h}$ & $1.5 \mathrm{~h}$ \\
\hline $\mathrm{CH}_{3} \mathrm{CHCHCH}_{2} \mathrm{OH}$ & 87 & $1.3 \mathrm{~h}$ & 25 & $1.1 \mathrm{~h}$ & 3.9 & $15 \mathrm{~min}$ & $11 \mathrm{~min}$ \\
\hline $\mathrm{CH}_{2} \mathrm{CHCH}_{2} \mathrm{CH}_{2} \mathrm{OH}$ & 55 & $2.0 \mathrm{~h}$ & 0.49 & $2.4 \mathrm{~d}$ & - & - & $1.9 \mathrm{~h}$ \\
\hline $\mathrm{CH}_{2} \mathrm{CHCH}(\mathrm{OH}) \mathrm{CH}_{3}$ & 59 & $1.9 \mathrm{~h}$ & 1.6 & $17.4 \mathrm{~h}$ & 0.12 & $7.7 \mathrm{~h}$ & $1.4 \mathrm{~h}$ \\
\hline $\mathrm{CH}_{3} \mathrm{CH}_{2} \mathrm{CHCHCH}_{2} \mathrm{OH}$ & 117 & $1.0 \mathrm{~h}$ & 16.9 & $1.6 \mathrm{~h}$ & 1.56 & $35 \mathrm{~min}$ & $18 \mathrm{~min}$ \\
\hline $\mathrm{CH}_{2} \mathrm{CHCH}(\mathrm{OH}) \mathrm{CH}_{2} \mathrm{CH}_{3}$ & 74 & $1.5 \mathrm{~h}$ & 1.79 & $1.6 \mathrm{~h}$ & 0.142 & $6.5 \mathrm{~h}$ & $42 \mathrm{~min}$ \\
\hline $\mathrm{CH}_{2} \mathrm{C}\left(\mathrm{CH}_{3}\right) \mathrm{CH}_{2} \mathrm{OH}$ & 90 & $1.2 \mathrm{~h}$ & - & - & - & - & $1.2 \mathrm{~h}$ \\
\hline$\left(\mathrm{CH}_{3}\right)_{2} \mathrm{CCHCH}_{2} \mathrm{OH}$ & 160 & $0.7 \mathrm{~h}$ & - & - & 9.6 & $5 \mathrm{~min}$ & $4.5 \mathrm{~min}$ \\
\hline $\mathrm{CH}_{2} \mathrm{C}\left(\mathrm{CH}_{3}\right) \mathrm{CH}_{2} \mathrm{CH}_{2} \mathrm{OH}$ & 94 & $1.2 \mathrm{~h}$ & - & - & 2.6 & $21 \mathrm{~min}$ & $16 \mathrm{~min}$ \\
\hline $\mathrm{CH}_{2} \mathrm{CHC}(\mathrm{OH})\left(\mathrm{CH}_{3}\right)_{2}$ & 63 & $1.8 \mathrm{~h}$ & 0.9 & $1.3 \mathrm{~d}$ & 0.12 & $7.7 \mathrm{~h}$ & $1.4 \mathrm{~h}$ \\
\hline cis-4-hexen-1-ol & $100 *$ & $1.1 \mathrm{~h}$ & - & - & 2.93 & $19 \mathrm{~min}$ & $15 \mathrm{~min}$ \\
\hline trans-3-hexen-1-ol & $100 *$ & $1.1 \mathrm{~h}$ & - & - & 4.43 & $13 \mathrm{~min}$ & $11 \mathrm{~min}$ \\
\hline cis-2-hexen-1-ol & $100 *$ & $1.1 \mathrm{~h}$ & - & - & 1.56 & $36 \mathrm{~min}$ & $23 \mathrm{~min}$ \\
\hline trans-2-hexen-1-ol & $100 *$ & $1.1 \mathrm{~h}$ & - & - & 1.3 & $43 \mathrm{~min}$ & $26 \mathrm{~min}$ \\
\hline cis-3-hexen-1-ol & 107 & $1.0 \mathrm{~h}$ & 8.6 & $3.2 \mathrm{~h}$ & 2.7 & $21 \mathrm{~min}$ & 14 min \\
\hline 2,6-dimethyl-7-octen-2-ol & 38 & $2.9 \mathrm{~h}$ & $<0.2$ & $>5.8 \mathrm{~d}$ & - & - & $2.9 \mathrm{~h}$ \\
\hline
\end{tabular}




\begin{tabular}{|c|c|c|c|c|c|c|c|}
\hline [Dihydromyrcenol] & & & & & & & \\
\hline $\begin{array}{l}\text { 3,7-dimethyl-1,6-octadien-3-ol } \\
\text { [Linalool] }\end{array}$ & 190 & $0.6 \mathrm{~h}$ & 44 & $38 \mathrm{~min}$ & 110 & $0.5 \mathrm{~min}$ & $0.5 \mathrm{~min}$ \\
\hline $\begin{array}{l}\text { 2,6-dimethyl-2,6-octadien-8-ol } \\
\text { [Geraniol] }\end{array}$ & 230 & $0.5 \mathrm{~h}$ & 93 & $18 \mathrm{~min}$ & & & $11 \mathrm{~min}$ \\
\hline $\begin{array}{l}\text { 3,7-dimethyl-6-octen-1-ol } \\
\text { [Citronellol] }\end{array}$ & 170 & $0.7 \mathrm{~h}$ & 24 & $1.2 \mathrm{~h}$ & & & $26.5 \mathrm{~min}$ \\
\hline $\begin{array}{l}\text { 2-(4-methylcyclohex-3-en-1- } \\
\text { yl)propan-2-ol [ } \alpha \text {-Terpineol] }\end{array}$ & 190 & $0.6 \mathrm{~h}$ & 30 & $56 \min$ & & & $22 \min$ \\
\hline 2-Propyn-1-ol & 9.2 & $1.3 \mathrm{~d}$ & - & - & - & - & $1.3 \mathrm{~d}$ \\
\hline 3,5-Dimethyl-1-hexyn-3-ol & 29 & $3.8 \mathrm{~h}$ & - & - & - & - & $3.8 \mathrm{~h}$ \\
\hline \multicolumn{8}{|l|}{ Aromatic Alcohols } \\
\hline Phenol & 28 & $4.0 \mathrm{~h}$ & - & - & 45 & $1.2 \mathrm{~min}$ & $1.2 \mathrm{~min}$ \\
\hline o-Cresol & 46 & $2.4 \mathrm{~h}$ & 0.026 & $45 \mathrm{~d}$ & 140 & $0.4 \mathrm{~min}$ & $0.4 \mathrm{~min}$ \\
\hline m-Cresol & 62 & $1.8 \mathrm{~h}$ & 0.019 & $61 \mathrm{~d}$ & 100 & $0.6 \mathrm{~min}$ & $0.6 \mathrm{~min}$ \\
\hline p-Cresol & 50 & $2.2 \mathrm{~h}$ & 0.047 & $25 \mathrm{~d}$ & 110 & $0.5 \mathrm{~min}$ & $0.5 \mathrm{~min}$ \\
\hline Benzyl alcohol & 27 & $4.1 \mathrm{~h}$ & $\leq 0.06$ & $>19 \mathrm{~d}$ & - & - & \\
\hline 2,3-Dimethylphenol & 82 & $1.4 \mathrm{~h}$ & - & - & 297 & $0.2 \mathrm{~min}$ & $0.2 \mathrm{~min}$ \\
\hline 2,4-Dimethylphenol & 73 & $1.5 \mathrm{~h}$ & - & - & 312 & $0.2 \mathrm{~min}$ & $0.2 \mathrm{~min}$ \\
\hline
\end{tabular}




\begin{tabular}{|c|c|c|c|c|c|c|c|}
\hline 2,5-Dimethylphenol & 85 & $1.3 \mathrm{~h}$ & - & - & 307 & $0.2 \mathrm{~min}$ & $0.2 \mathrm{~min}$ \\
\hline 2,6-Dimethylphenol & 66 & $1.7 \mathrm{~h}$ & - & - & 501 & $0.1 \mathrm{~min}$ & $0.1 \mathrm{~min}$ \\
\hline 3,4-Dimethylphenol & 83 & $1.3 \mathrm{~h}$ & - & - & 255 & $0.2 \mathrm{~min}$ & $0.2 \mathrm{~min}$ \\
\hline 3,5-Dimethylphenol & 114 & $1.0 \mathrm{~h}$ & - & - & 113 & $0.5 \mathrm{~min}$ & $0.5 \mathrm{~min}$ \\
\hline 2,3,5-Trimethyphenol & 125 & $0.9 \mathrm{~h}$ & - & - & - & - & \\
\hline 2,3,6-Trimethylphenol & 118 & $1.0 \mathrm{~h}$ & - & - & - & - & \\
\hline 1,2-Benzendiol & 104 & $1.1 \mathrm{~h}$ & 0.93 & $1.2 \mathrm{~d}$ & 980 & $0.06 \mathrm{~min}$ & $0.06 \mathrm{~min}$ \\
\hline 3-Methyl-1,2-benzendiol & 198 & $0.6 \mathrm{~h}$ & 2.8 & $9.9 \mathrm{~h}$ & 1720 & $0.03 \mathrm{~min}$ & $0.03 \mathrm{~min}$ \\
\hline 4-Methyl-1,2-benzendiol & 156 & $0.7 \mathrm{~h}$ & 2.6 & $10.7 \mathrm{~h}$ & 1470 & $0.04 \mathrm{~min}$ & $0.04 \mathrm{~min}$ \\
\hline
\end{tabular}

* Estimated

${ }^{\mathrm{a}} k_{\mathrm{OH},} k_{\mathrm{NO} 3}$ and $k_{\mathrm{O} 3}$ : rate constants of the reactions with $\mathrm{OH}, \mathrm{NO}_{3}$ radicals and $\mathrm{O}_{3}$ in $\mathrm{cm}^{3}$ molecule ${ }^{-1} \mathrm{~s}^{-1}$ at $298 \mathrm{~K}$ and 1 bar, data taken from Calvert et al. ${ }^{8}$

${ }^{\mathrm{b}}$ Lifetimes estimated by $\tau_{\mathrm{X}}=1 / k_{x}[\mathrm{X}]$, where $k$ is the rate constant for reaction of the OVOC with oxidants and [X] is the oxidant concentration; $[\mathrm{OH}]=10^{6}$ (24-hr average) for OVOCs with lifetimes > 1 day or $2.5 \times 10^{6}$ (typical day-time concentration) for OVOCs with lifetimes $<1$ day, $\left[\mathrm{O}_{3}\right]=10^{12}$ (24-hr average), and $\left[\mathrm{NO}_{3}\right]=3 \times 10^{9}$ molecule $\mathrm{cm}^{-3}$ (night-time value in polluted urban 
environments). Oxidant concentrations vary in time and space, the atmospheric lifetimes of OVOCs emitted at a particular place and time could be longer, or shorter, than the representative values listed above.

${ }^{\mathrm{c}} \mathrm{NO}_{3}$ radical concentrations during the day-time are very low, lifetimes exceeding 12 hours calculated using the night-time value for polluted urban areas have been multiplied by a factor of 2 to facilitate comparison with lifetimes calculated using 24-hour average $[\mathrm{OH}]$ values.

${ }^{\mathrm{d}}$ Wet and dry deposition is an important atmospheric removal process for these compounds, see text for details. 
The degradation of aliphatic alcohols under atmospheric conditions proceeds by $\mathrm{H}$-atom abstraction from various $\mathrm{C}-\mathrm{H}$ groups in the alkyl chain. $\mathrm{H}$-atom abstraction from the $\mathrm{O}-\mathrm{H}$ group in alcohols occurs with a rate constant of approximately $2 \times 10^{-13} \mathrm{~cm}^{3}$ molecule $\mathrm{s}^{-1}$ at $298 \mathrm{~K}$ and is of minor importance. In the reaction of $\mathrm{OH}$ with $\mathrm{CH}_{3} \mathrm{OH}, \mathrm{H}$-atom abstraction from $\mathrm{CH}_{3^{-}}$group represents $\approx 85 \%$ and that from $-\mathrm{OH}$ about $15 \%$ of the overall reaction at $298 \mathrm{~K}$. In the reaction of $\mathrm{OH}$ with $\mathrm{CH}_{3} \mathrm{CH}_{2} \mathrm{OH}$, the abstraction occurs mainly from the $-\mathrm{CH}_{2}$ - group $(75 \pm 15 \%)$, while abstraction from the $\mathrm{CH}_{3}$ and $\mathrm{OH}$ groups represents approximately 5\% for each channel. For linear-chain alcohols with three or more carbon atoms, $\mathrm{H}$-atom abstraction from the $\alpha$-carbon atom is likely to be the main reaction pathway, while abstraction from $\beta$-, $\gamma$ - and $\delta$-carbon atoms will also make a significant contribution to the reaction products.

The oxidation products are carbonyl compounds such as aldehydes, ketones and hydroxycarbonyls. Scheme 1 shows a simplified $\mathrm{OH}$-initiated degradation scheme for 2-butanol $\left(\mathrm{CH}_{3} \mathrm{CH}(\mathrm{OH}) \mathrm{CH}_{2} \mathrm{CH}_{3}\right)$. The reaction proceeds predominately via $\mathrm{H}$-atom abstraction from the tertiary $\mathrm{C}-\mathrm{H}$ and secondary $-\mathrm{CH}_{2}-$ bonds, $\mathrm{H}$-atom abstraction from the primary $\mathrm{CH}_{3}-$ and $-\mathrm{OH}$ groups is of minor importance. $\mathrm{H}$-atom abstraction from the tertiary $\mathrm{C}-\mathrm{H}$ bond leading to pentanone $\left(\mathrm{CH}_{3} \mathrm{C}(\mathrm{O}) \mathrm{CH}_{2} \mathrm{CH}_{3}\right)$ accounts for $\approx 65 \%$ and $\mathrm{H}$-atom abstraction from the secondary $\mathrm{CH}_{2}$ - bond leading to acetaldehyde accounts for approximately $30 \%$ of the overall reaction. ${ }^{42-43}$ 


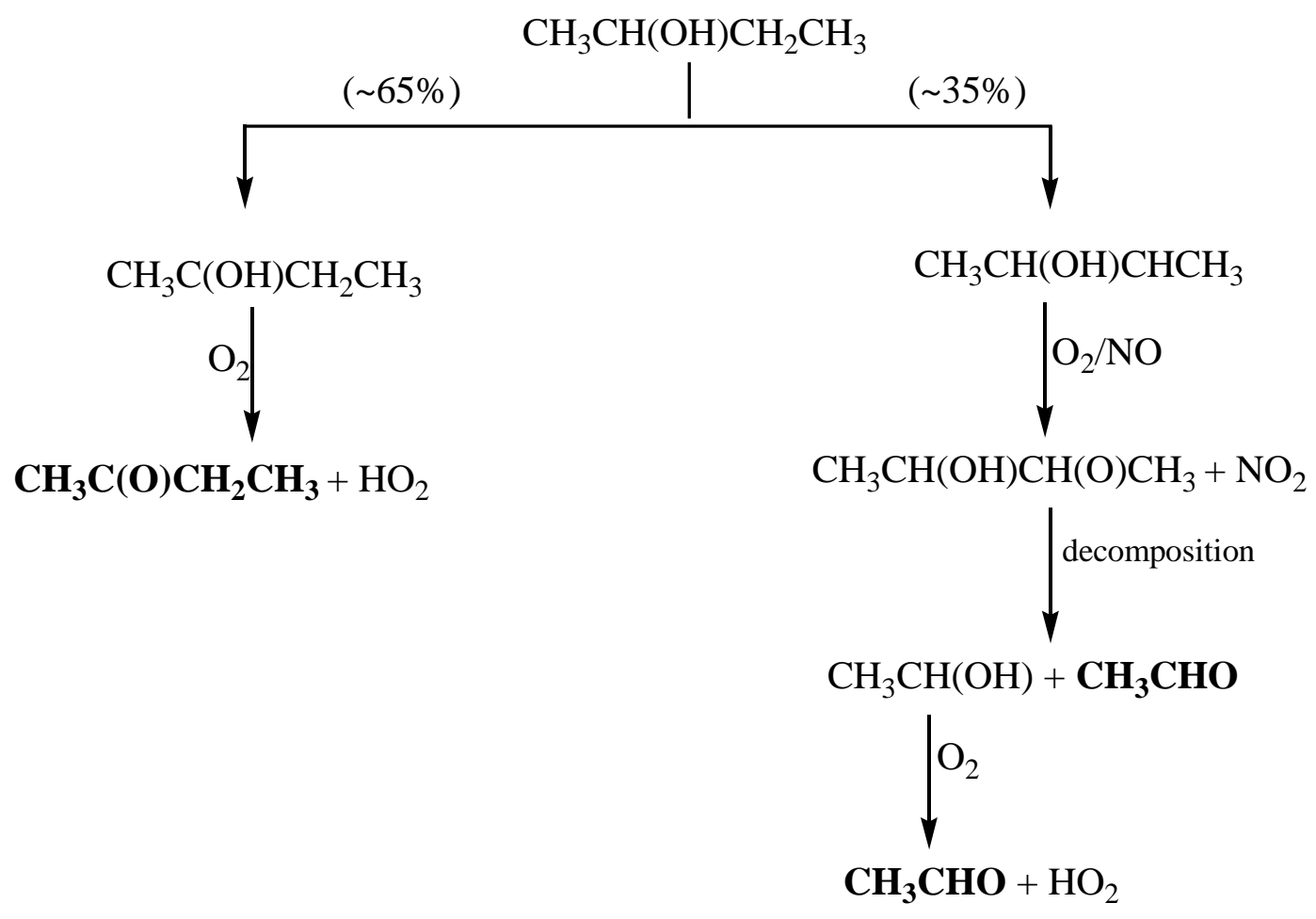

Scheme 1. Simplified degradation scheme for the OH-initiated oxidation of 2-butanol

Similarly to aliphatic alcohols, diols are also oxidized in the atmosphere via reaction with $\mathrm{OH}$ radicals. However, their reactivity is higher than that of the corresponding monoalcohols. ${ }^{44-46}$ The tropospheric lifetime of the diols is less than a day. Reaction of $\mathrm{OH}$ with diols proceeds via the same mechanism as for monoalcohols. $\mathrm{H}$-atom abstraction from $>\mathrm{CH}(\mathrm{OH})$ or $-\mathrm{CH}_{2}(\mathrm{OH})$ groups leads to the formation of carbonyl containing compounds: e.g., $\mathrm{HOCH}_{2} \mathrm{C}(\mathrm{O}) \mathrm{CH}_{2} \mathrm{CH}_{3}$ from $\mathrm{HOCH}_{2} \mathrm{CH}(\mathrm{OH}) \mathrm{CH}_{2} \mathrm{CH}_{3}, \quad \mathrm{HOCH}_{2} \mathrm{CH}_{2} \mathrm{C}(\mathrm{O}) \mathrm{CH}_{3}$ from $\mathrm{HOCH}_{2} \mathrm{CH}_{2} \mathrm{CH}(\mathrm{OH}) \mathrm{CH}_{3}$, 
$\mathrm{CH}_{3} \mathrm{CH}(\mathrm{OH}) \mathrm{C}(\mathrm{O}) \mathrm{CH}_{3}$ from $\mathrm{CH}_{3} \mathrm{CH}(\mathrm{OH}) \mathrm{CH}(\mathrm{OH}) \mathrm{CH}_{3}$ and $\left(\mathrm{CH}_{3}\right)_{2} \mathrm{CH}(\mathrm{OH}) \mathrm{CH}_{2} \mathrm{C}(\mathrm{O}) \mathrm{CH}_{3}$ from $\left(\mathrm{CH}_{3}\right)_{2} \mathrm{C}(\mathrm{OH}) \mathrm{CH}_{2} \mathrm{CH}(\mathrm{OH}) \mathrm{CH}_{3} .{ }^{45-46}$

Cyclic alcohols are removed from the atmosphere mainly via reaction with $\mathrm{OH}$ radicals and have lifetimes of the order of hours. The reaction is expected to occur predominately via $\mathrm{H}$-atom from the $\alpha$-position leading to the corresponding cycloketones. H-atom abstraction from the other positions ( $\beta$ - and $\gamma$-) may also contribute to the reaction. The overall reaction leads to products arising from ring retaining and cleavage degradation pathways. The $\mathrm{OH}$-initiated oxidation of cyclohexanol has been reported to form cyclohexanone, 3-hydroxycyclohexanone and 4hydroxycyclohexanone as ring retaining products and hexanedial from the cleavage of the ring. ${ }^{47}$ The main gas phase oxidation routes of aromatic alcohols in the atmosphere are their reactions with $\mathrm{OH}$ and $\mathrm{NO}_{3}$ radicals. ${ }^{8,48-49}$ Their lifetimes are of the order of a few hours. The reaction of $\mathrm{OH}$ may proceed through $\mathrm{H}$-abstraction and $\mathrm{OH}$-addition to the aromatic ring. The relative importance of these channels depends on the temperature. The available kinetic and mechanistic data indicate that for the atmospherically relevant temperature range, the reaction proceeds mainly via the addition channel. $\mathrm{H}$-atom abstraction from the $-\mathrm{OH}$ group is of minor importance and accounts for $<10 \%$ of the overall reaction at $298 \mathrm{~K}$. Mechanistic studies have shown that the OH-initiated oxidation of phenols and cresols produces the corresponding nitrophenols, benzoquinones, and dihydroxybenzenes. ${ }^{8}$ The reaction of $\mathrm{NO}_{3}$ with aromatic alcohols can 
produce nitrophenols and other nitro-containing aromatic compounds with high yields indicating that the $\mathrm{H}$-atom abstraction channel is of importance.

Unsaturated Alcohols $\left(R_{1} R_{2} C=C R_{3} R_{4}(\mathrm{OH})\right)$ : Unsaturated alcohols are very reactive towards atmospheric oxidants, $\mathrm{OH}$ and $\mathrm{NO}_{3}$ radicals and $\mathrm{O}_{3}$, their atmospheric degradation is controlled via chemical reactions with these oxidants. The atmospheric lifetimes of the unsaturated alcohols are shorter than their aliphatic analogues and are in the range of hours to minutes. They will be rapidly oxidized near their emission sources and may contribute to local ozone formation.

The $\mathrm{OH}$-initiated oxidation of unsaturated alcohols is expected to proceed mainly by addition of $\mathrm{OH}$ to the $\mathrm{C}=\mathrm{C}$ bond to form a series of hydroxyalkyl radicals which in general add $\mathrm{O}_{2}$ and then react with NO to give the corresponding hydroxalkoxy radicals. The fate of the hydroxalkoxy radicals is decomposition, isomerisation and reaction with $\mathrm{O}_{2}$ depending on their chemical structure. Hydroxyaldehydes and dihydroxycarbonyls have been reported among the main end products arising from the reaction of $\mathrm{OH}$ with unsaturated alcohols. ${ }^{50-53}$

The reaction of ozone with unsaturated alcohols is expected to involve, as for other olefins, electrophilic addition at the carbon-carbon double bond leading to the formation of a trioxide followed by its unimolecular decomposition into two carbonyls and two biradicals (Criegee Intermediates, CIs). ${ }^{54-56}$ CIs may form other carbonyls and free radicals such as $\mathrm{HO}_{\mathrm{x}}$ and contribute to the formation of SOA. 
The reaction of $\mathrm{NO}_{3}$ with unsaturated alcohols occurs predominantly via addition to the more substituted carbon atom in the $\mathrm{C}=\mathrm{C}$ bond which leads under atmospheric conditions to the formation of nitrooxyalkyl peroxy radicals which react with $\mathrm{NO}$ to give the corresponding nitrooxyalkyl alkoxy radicals. These later radicals can decompose, isomerise or react with $\mathrm{O}_{2}$ leading to carbonyls and nitrooxycarbonyls compounds as main end products. ${ }^{57-58}$

\subsection{Ethers}

Ethers are widely used in chemical industry, they are also used as fuels and fuel additives.

Aliphatic Ethers, Polyethers, Cyclic Ethers, Alkoxy Alcohols and Alkoxy Esters: The atmospheric degradation of ethers, polyethers, cyclic ethers, alkoxy alcohols and alkoxy esters in the troposphere is predominantly initiated by reaction with $\mathrm{OH}$ radicals. Reaction with $\mathrm{NO}_{3}$ radicals during the night-time contributes, to a small extent, to the atmospheric removal of some ethers. Ethers do not absorb significantly at wavelengths $>200 \mathrm{~nm}$ and hence photolysis is not a significant atmospheric loss mechanism. ${ }^{8}$ For unsaturated ethers reaction with $\mathrm{O}_{3}$ can compete with reaction with $\mathrm{OH}$ and $\mathrm{NO}_{3}$ radicals as an important loss mechanism.

The available rate constant data at room temperature for reactions of $\mathrm{OH}$ with linear chain ethers

show a large increase in reactivity with increasing chain length. The reactivity of $\mathrm{OH}$ radicals towards ethers is greater than that of the corresponding alkanes, which has been attributed to the 
activating effect of the ether group (-O-). For example, compare: $k\left(\mathrm{OH}+\mathrm{CH}_{3} \mathrm{OCH}_{3}\right)=2.8 \times 10^{-12}$ with $k\left(\mathrm{OH}+\mathrm{CH}_{3} \mathrm{CH}_{3}\right)=0.24 \times 10^{-12} ; \mathrm{k}\left(\mathrm{C}_{2} \mathrm{H}_{5} \mathrm{OC}_{2} \mathrm{H}_{5}\right)=12.2 \times 10^{-12}$ with $k\left(\mathrm{OH}+\mathrm{n}-\mathrm{C}_{4} \mathrm{H}_{10}\right)=2.36 \times 10^{-}$ ${ }^{12}$, and $k\left(\mathrm{OH}+\mathrm{n}-\mathrm{C}_{3} \mathrm{H}_{7} \mathrm{OC}_{3} \mathrm{H}_{7}\right)=20 \times 10^{-12}$ with $k\left(\mathrm{OH}+\mathrm{n}-\mathrm{C}_{6} \mathrm{H}_{14}\right)=5.27 \times 10^{-12} \mathrm{~cm}^{3}$ molecule $^{-1} \mathrm{~s}^{-}$ ${ }^{1,441,59}$ The $\mathrm{OH}$ reaction rate constants at room temperature range from $\approx 3 \times 10^{-12}$ for $\mathrm{CH}_{3} \mathrm{OCH}_{3}$ to $\approx 30 \times 10^{-12} \mathrm{~cm}^{3}$ molecule $\mathrm{s}^{-1}$ for larger ethers such as di-n-butyl ether $\left(\mathrm{CH}_{3}\left(\mathrm{CH}_{2}\right)_{3} \mathrm{O}\left(\mathrm{CH}_{2}\right)_{3} \mathrm{CH}_{3}\right)$ and di-n-pentyl ether $\left(\mathrm{CH}_{3}\left(\mathrm{CH}_{2}\right)_{4} \mathrm{O}\left(\mathrm{CH}_{2}\right)_{4} \mathrm{CH}_{3}\right)$. Combining these values with an average daytime $[\mathrm{OH}]$ of $2.5 \times 10^{6} \mathrm{~cm}^{-3}$ for molecules with lifetimes $<1$ day and a diurnal average $[\mathrm{OH}]$ of $1 \times 10^{6} \mathrm{~cm}^{-3}$ for molecules with lifetimes $>1$ day, ${ }^{8}$ provides a range of 4 hours to 4 days for the atmospheric lifetimes of typical ethers. The degradation of ethers in the atmosphere leads mainly to formates, acetates and other carbonyl-containing products. To illustrate the typical atmospheric degradation mechanism of ethers, scheme 2 shows the $\mathrm{OH}$ initiated degradation of one of the simplest ethers, diethyl ether $\left(\mathrm{CH}_{3} \mathrm{CH}_{2} \mathrm{OCH}_{2} \mathrm{CH}_{3}\right)$. The main oxidation products of diethyl ether reported in the literature are ethyl formate, ethyl acetate, acetaldehyde and formaldehyde. ${ }^{60-63}$ The reaction proceeds mainly by $\mathrm{H}$-atom abstraction from the $-\mathrm{CH}_{2}$ - groups followed by reaction with $\mathrm{O}_{2}$ to give a peroxy radical which reacts with $\mathrm{NO}$ to form the alkoxy radical $\mathrm{C}_{2} \mathrm{H}_{5} \mathrm{OC}(\mathrm{O}) \mathrm{HCH}_{3}$. It has been shown in chamber studies that a substantial fraction of these alkoxy radicals are formed chemically activated. ${ }^{63}$ The chemically activated alkoxy radicals either undergo "prompt" non-thermal decomposition or are thermalized 
by collisions. In the case of $\mathrm{C}_{2} \mathrm{H}_{5} \mathrm{OC}(\mathrm{O}) \mathrm{HCH}_{3}$ radicals formed in reaction of the corresponding peroxy radical with $\mathrm{NO}$, approximately $50 \%$ undergo prompt decomposition via elimination of $\mathrm{CH}_{3}$ radicals or $\mathrm{H}$-atoms. The remaining alkoxy radicals are thermalized and undergo decomposition (mainly via $\mathrm{C}-\mathrm{C}$ bond scission with a minor channel via $\mathrm{C}-\mathrm{O}$ bond scission) and reaction with $\mathrm{O}_{2}$ as shown in Scheme 2 .

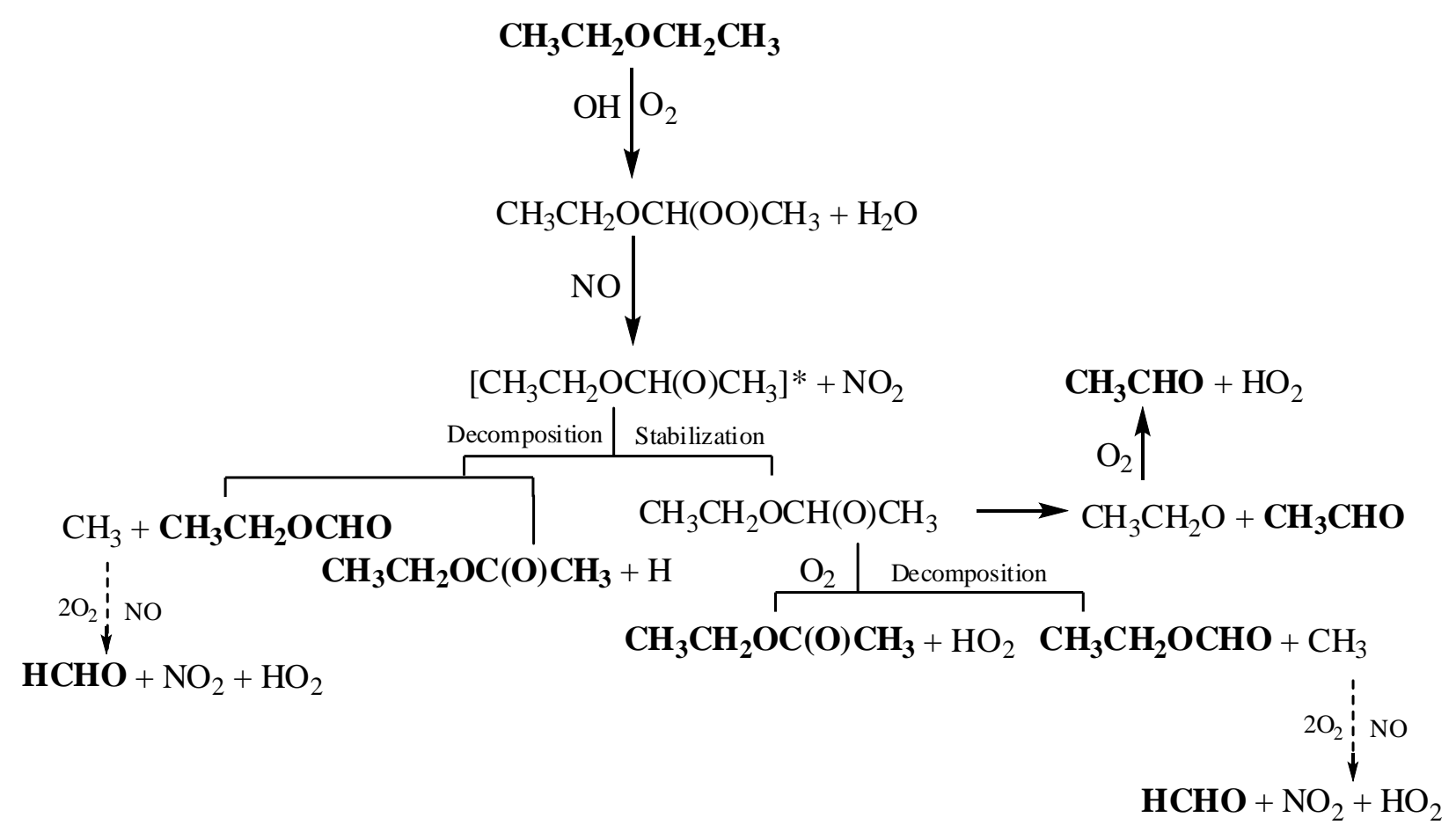

Scheme 2. OH-initiated oxidation of diethyl ether under atmospheric conditions.

Polyethers and cyclic ethers with the exception of ethylene oxide (cyclo- $\mathrm{C}_{2} \mathrm{H}_{4} \mathrm{O}-$ ) and propylene oxide $\left(\mathrm{CH}_{3}\right.$-cyclo- $\left.\mathrm{C}_{2} \mathrm{H}_{3} \mathrm{O}-\right)$ are very reactive towards $\mathrm{OH}$ radicals $\left(\mathrm{k}_{\mathrm{OH}} \approx(1-50) \times 10^{-12} \mathrm{~cm}^{3}\right.$ molecule $^{-1} \mathrm{~s}^{-1}$, respectively). Their atmospheric lifetimes with respect to reaction with $\mathrm{OH}$ 
radicals are in the range 2 hours to 12 days. Similarly to aliphatic ethers, the main $\mathrm{OH}$-initiated oxidation products of polyethers and cycloethers are formates and acetates. The oxidation of polyethers and cycloethers oxidation leads to the formation of highly oxygenated compounds such as methoxymethyl formate $\left(\mathrm{CH}_{3} \mathrm{OCH}_{2} \mathrm{OCHO}\right)$ and dimethyl carbonate $\left(\mathrm{CH}_{3} \mathrm{OC}(\mathrm{O}) \mathrm{OCH}_{3}\right)$ from dimethoxymethane $\left(\mathrm{CH}_{3} \mathrm{OCH}_{2} \mathrm{OCH}_{3}\right),{ }^{64-66}$ and methylene glycol diformate $\left(\mathrm{HC}(\mathrm{O}) \mathrm{OCH}_{2} \mathrm{OCHO}\right)$ from 1,3-dioxolane ${ }^{67}$. The reaction rate constants of $\mathrm{OH}$ with ethylene oxide and propylene oxide are $k_{\mathrm{OH}} \approx 9 \times 10^{-14}$ and $\approx 5 \times 10^{-13} \mathrm{~cm}^{3}$ molecule $\mathrm{e}^{-1} \mathrm{~s}^{-1}$ and these species have lifetimes of approximately 4 months and 1 month, respectively.

The $\mathrm{OH}$ reaction rate constants with alkoxyethers are larger than $10^{-11} \mathrm{~cm}^{3}$ molecule $\mathrm{s}^{-1}$ leading to atmospheric lifetimes for these species of 10 hours, or less, in the sunlit troposphere. The available mechanistic data show that the reactions produce mainly carbonyl products such as esters, hydroxyesters, hydroxyaldehydes, alkoxyaldehydes and alkoxyketones. The reactivity of $\mathrm{OH}$ radicals with alkoxy esters range from $\approx 1 \times 10^{-12}$ for $\mathrm{HC}(\mathrm{O}) \mathrm{OCH}_{2} \mathrm{OCH}_{3}$ to $\approx(10-20) \times 10^{-12}$ $\mathrm{cm}^{3}$ molecule $\mathrm{s}^{-1}$ for $\mathrm{CH}_{3} \mathrm{C}(\mathrm{O}) \mathrm{OCH}_{2} \mathrm{CH}_{2} \mathrm{OC}_{2} \mathrm{H}_{5}$ and $\mathrm{C}_{2} \mathrm{H}_{5} \mathrm{OCH}_{2} \mathrm{CH}_{2} \mathrm{C}(\mathrm{O}) \mathrm{OC}_{2} \mathrm{H}_{5}$. The calculated lifetimes for these compounds range from half a day to around a week. The main $\mathrm{OH}$-initiated oxidation products reported are formates among which some are highly oxygenated, containing four oxygen atoms or more. These species might play a role in secondary organic aerosol (SOA) formation. 
Unsaturated ethers: The atmospheric fate of unsaturated ethers is controlled by reactions with $\mathrm{OH}, \mathrm{NO}_{3}$ and $\mathrm{O}_{3}$. Unsaturated ethers are very reactive towards these atmospheric oxidants. The reaction rate constant values are greater than those with the corresponding alkenes indicating an activating effect of the ether group (-O-) on the $>\mathrm{C}=\mathrm{C}<$ double bond. The rate constant values are in the range $(4-10) \times 10^{-11} \mathrm{~cm}^{3}$ molecule $\mathrm{s}^{-1}$ for $\mathrm{OH},>10^{-13}$ for $\mathrm{NO}_{3}$ and $>10^{-16}$ for $\mathrm{O}_{3}$ leading to very short atmospheric lifetimes for the unsaturated ethers, of the order of hours to minutes. ${ }^{68-}$

${ }^{71}$ The reactions proceed mainly through addition of the oxidants to the $>\mathrm{C}=\mathrm{C}<$ bond leading to carbon-carbon bond scission and shorter chain length carbonyl products (nitrate products in the case of reaction with $\left.\mathrm{NO}_{3}\right) .{ }^{55,68,72-74}$ A non-negligible yield formation of secondary organic aerosol has been reported for the ozonolysis reactions. ${ }^{72,75-76}$

\subsection{Aldehydes}

Aldehydes are emitted directly to the atmosphere from anthropogenic and natural sources or produced in-situ as intermediates in the oxidation of other VOCs.

Aliphatic Aldehydes, hydroxyaldehydes, dialdehydes, cyclic and aromatic aldehydes: The atmospheric degradation of aldehydes is controlled by photolysis and by reaction with $\mathrm{OH}$ radicals depending on their molecular structure. Photolysis is more important for branched-chain aldehydes compared to the linear chain ones. For the branched chain aldehydes, photolysis 
competes with $\mathrm{OH}$ reaction while reaction with $\mathrm{OH}$ radical is generally the dominant loss process for linear-chain aldehydes. The available kinetic data indicate that reactions of $\mathrm{NO}_{3}$ radicals and $\mathrm{O}_{3}$ with aldehydes are of negligible atmospheric importance. ${ }^{8}$

Formaldehyde (HCHO) is formed during the atmospheric degradation of all VOCs and is one of the most reactive and most important species in tropospheric photochemistry and ozone formation. ${ }^{8}$ Its degradation in the atmosphere is controlled both by photolysis and reaction with $\mathrm{OH}$ radicals. The rate of photolysis depends on the solar flux which depends on latitude, altitude, time of day, and day of the year. At an altitude of $0.5 \mathrm{~km}$ with overhead sun $\mathrm{HCHO}$ has a lifetime with respect to photolysis of around 3 hours. The photolysis channels are:

$$
\begin{aligned}
& \mathrm{HCHO}+h v \rightarrow \mathrm{HCO}+\mathrm{H} \\
& \mathrm{HCHO}+h v \rightarrow \mathrm{CO}+\mathrm{H}_{2} \\
& \mathrm{HCHO}+h v \rightarrow \mathrm{CO}+2 \mathrm{H}
\end{aligned}
$$

Channels (I) and (II) are important in the lower troposphere (Figure 8). Channel (III) is significant in the upper troposphere and stratosphere as discussed by Calvert et al. ${ }^{8}$ 


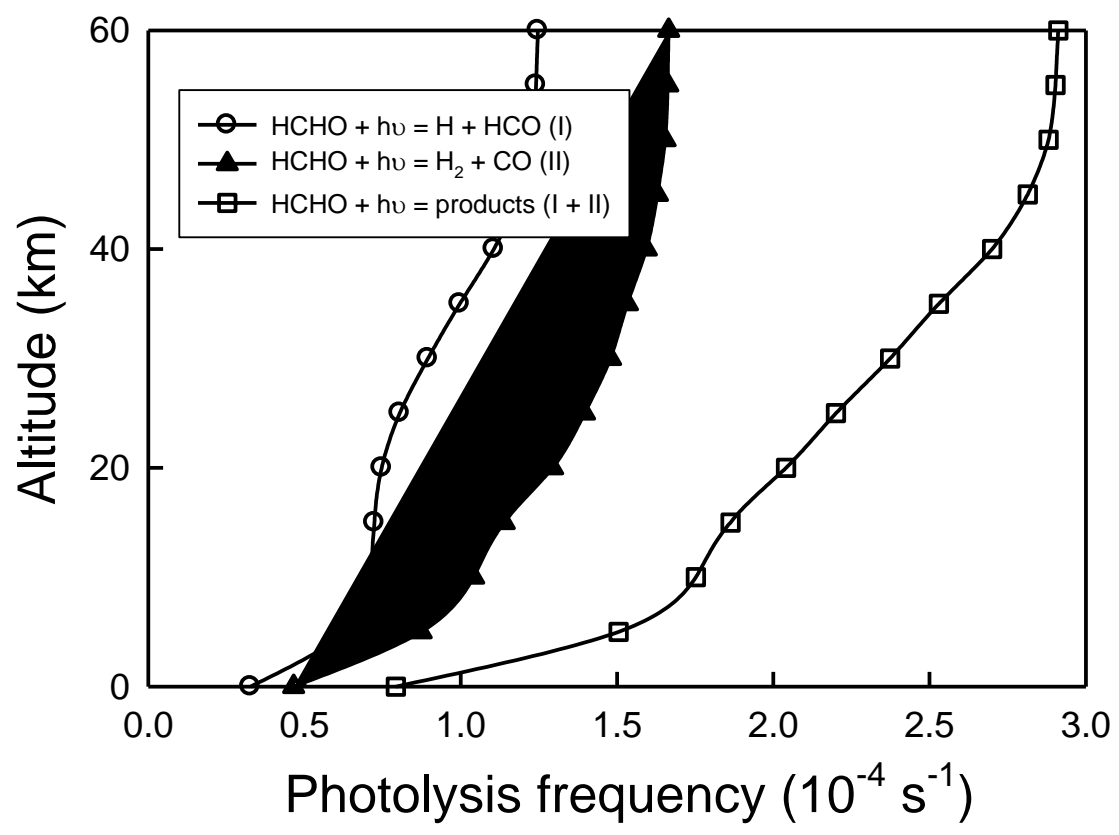

Figure 8. HCHO photolysis frequencies (j-values) for processes I and II and the total versus altitude calculated by Calvert et al. ${ }^{8}$ for a solar zenith angle of $45^{\circ}$ using the temperature and pressure effects characterized by Meller and Moortgat ${ }^{77}$. The increase with altitude reflects both increased actinic flux and decreased quenching.

The $\mathrm{HCHO}$ lifetime with respect to reaction with $\mathrm{OH}$ radicals is calculated to be around half a day. ${ }^{41}$ The reaction of $\mathrm{OH}$ with formaldehyde leads to $\mathrm{HCO}$ radicals. The subsequent reactions following the photolysis and reaction with $\mathrm{OH}$ in the presence of $\mathrm{NOx}$ lead ultimately to the generation of ozone through the mechanism shown in scheme 3 . 


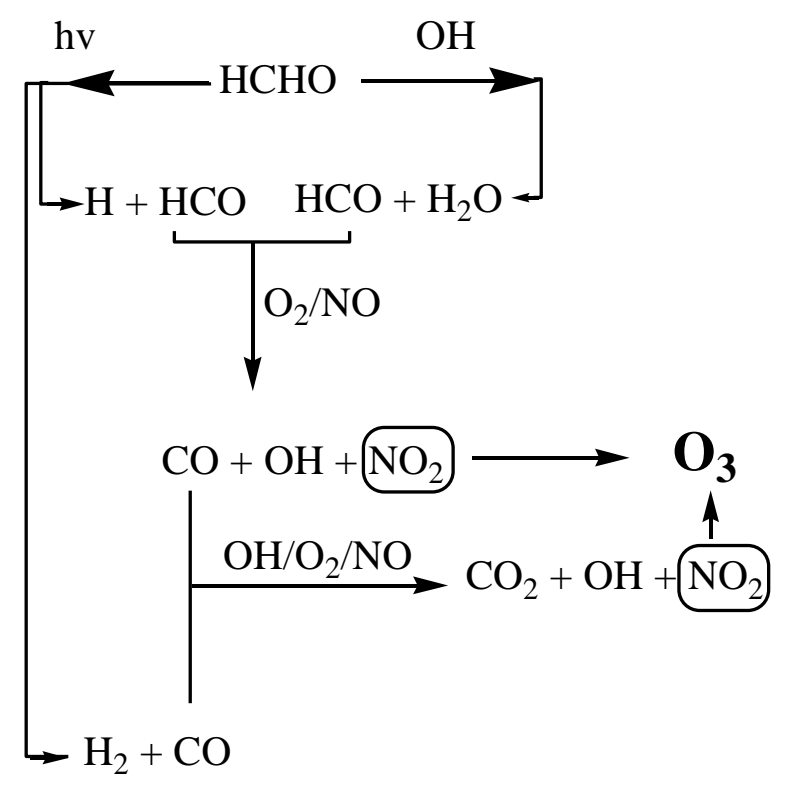

Scheme 3. Scheme of ozone formation through the atmospheric degradation of formaldehyde.

It has been shown recently that photo-tautomerization to vinyl alcohol is a significant atmospheric fate of acetaldehyde ${ }^{78}$ and that OH-initiated oxidation of enols may be an important source of carboxylic acids. ${ }^{79}$ The atmospheric importance of photo-tautomerization of aldehydes is unclear and the subject of current research. In general, photolysis of the other aldehydes is less competitive with the $\mathrm{OH}$ reaction but still important mainly at higher altitudes of the troposphere. ${ }^{8}$ The rate constants for reaction of $\mathrm{OH}$ with aldehydes are $\geq 10^{-11} \mathrm{~cm}^{3}$ molecule $\mathrm{s}^{-1}$ which result in short atmospheric lifetimes $\left(<12\right.$ hours for a typical daytime $[\mathrm{OH}]$ of $2.5 \times 10^{6}$ $\mathrm{cm}^{-3}$ ) for these compounds. The reaction occurs mainly through $\mathrm{H}$-atom abstraction from the 
aldehydic group (-CHO). Hydrogen atom abstraction from the $\mathrm{C}-\mathrm{H}$ bonds of the alkyl chain is of minor importance for small aldehydes but can be significant for larger aldehydes. The products arising from the $\mathrm{OH}$-initiated degradation of aldehydes are mainly shorter aldehydes and ketones. Abstraction of the aldehydic hydrogen gives acyl radicals which rapidly add $\mathrm{O}_{2}$ to give acylperoxy radicals. Acylperoxy radicals can add $\mathrm{NO}_{2}$ to give acylperoxy nitrates $\left(\mathrm{RC}(\mathrm{O}) \mathrm{O}_{2} \mathrm{NO}_{2}\right)$ :

$$
\begin{gathered}
\mathrm{RCHO}+\mathrm{OH}\left(+\mathrm{O}_{2}\right)+\mathrm{M} \rightarrow \mathrm{RC}(\mathrm{O}) \mathrm{O}_{2}+\mathrm{H}_{2} \mathrm{O}+\mathrm{M} \\
\mathrm{RC}(\mathrm{O}) \mathrm{O}_{2}+\mathrm{NO}_{2} \rightarrow \mathrm{RC}(\mathrm{O}) \mathrm{O}_{2} \mathrm{NO}_{2}+\mathrm{M}
\end{gathered}
$$

The most important member of this family is peroxyacetyl nitrate (PAN), $\mathrm{CH}_{3} \mathrm{C}(\mathrm{O}) \mathrm{O}_{2} \mathrm{NO}_{2}$, which is stable at low temperatures, constitutes a reservoir for $\mathrm{NO}_{\mathrm{x}}$, and provides through its transport a source of NOx in remote areas.

Hydroxyaldehydes and dialdehydes are decomposed within the atmosphere by reaction with $\mathrm{OH}$ and photolysis with this latter process being the dominant for short dialdehydes such as glyoxal $(\mathrm{HC}(\mathrm{O}) \mathrm{C}(\mathrm{O}) \mathrm{H})$ and methyl glyoxal $\left(\mathrm{CH}_{3} \mathrm{C}(\mathrm{O}) \mathrm{C}(\mathrm{O}) \mathrm{H}\right)$. The lifetimes for these compounds are of the order of a few hours.

The available kinetic and mechanistic data on the atmospheric degradation of cyclic aldehydes indicate that they are very reactive towards $\mathrm{OH}$ and $\mathrm{NO}_{3}$ radicals $\left(\mathrm{k}_{\mathrm{OH}} \geq 10^{-11}\right.$ and $\mathrm{k}_{\mathrm{NO} 3} \geq 10^{-15}$ $\mathrm{cm}^{3}$ molecule $\mathrm{s}^{-1} \mathrm{~s}^{-1}$ ). These rate constants values lead to lifetimes of the order of hours under 
atmospheric conditions. The reactions occur mainly through $\mathrm{H}$-atom abstraction from the $-\mathrm{CHO}$ group with a non negligible $\mathrm{H}$-atom abstraction from the ring, up to more than $10 \%$ as reported for cyclobutanecarbaldehyde. ${ }^{80}$ The abstraction of the aldehydic hydrogen atom may lead to the formation of peroxynitrates. Ring opening may occur following H-atom abstraction from the $\mathrm{CHO}$ group or from the ring and would lead to shorter carbonyls.

The degradation of aromatic aldehydes in the atmosphere is controlled by photolysis and reaction with $\mathrm{OH}$ radicals during the day. The $\mathrm{OH}$ reaction rate constants values are in the range (15) $\times 10^{-11} \mathrm{~cm}^{3}$ molecule $\mathrm{s}^{-1}$ leading to lifetimes with respect to $\mathrm{OH}$ reactions of approximately 4 15 hours. Reaction of benzaldehyde with $\mathrm{OH}$ occurs by abstraction of the aldehydic hydrogen atom leading ultimately to a series of stable compounds such as nitrophenols and peroxy benzoyl nitrate as shown in scheme 4. Photolysis is the dominant atmospheric loss for some aromatic aldehydes. o-Tolualdehyde has been found to be very rapidly photolysed under sunlight conditions with a lifetime of $\approx 2$ hours. Benzocyclobutenol and o-phthalaldehyde have been suggested as photolysis products as well as appreciable yields (5-13\%) of secondary organic aerosol. $^{81}$ 


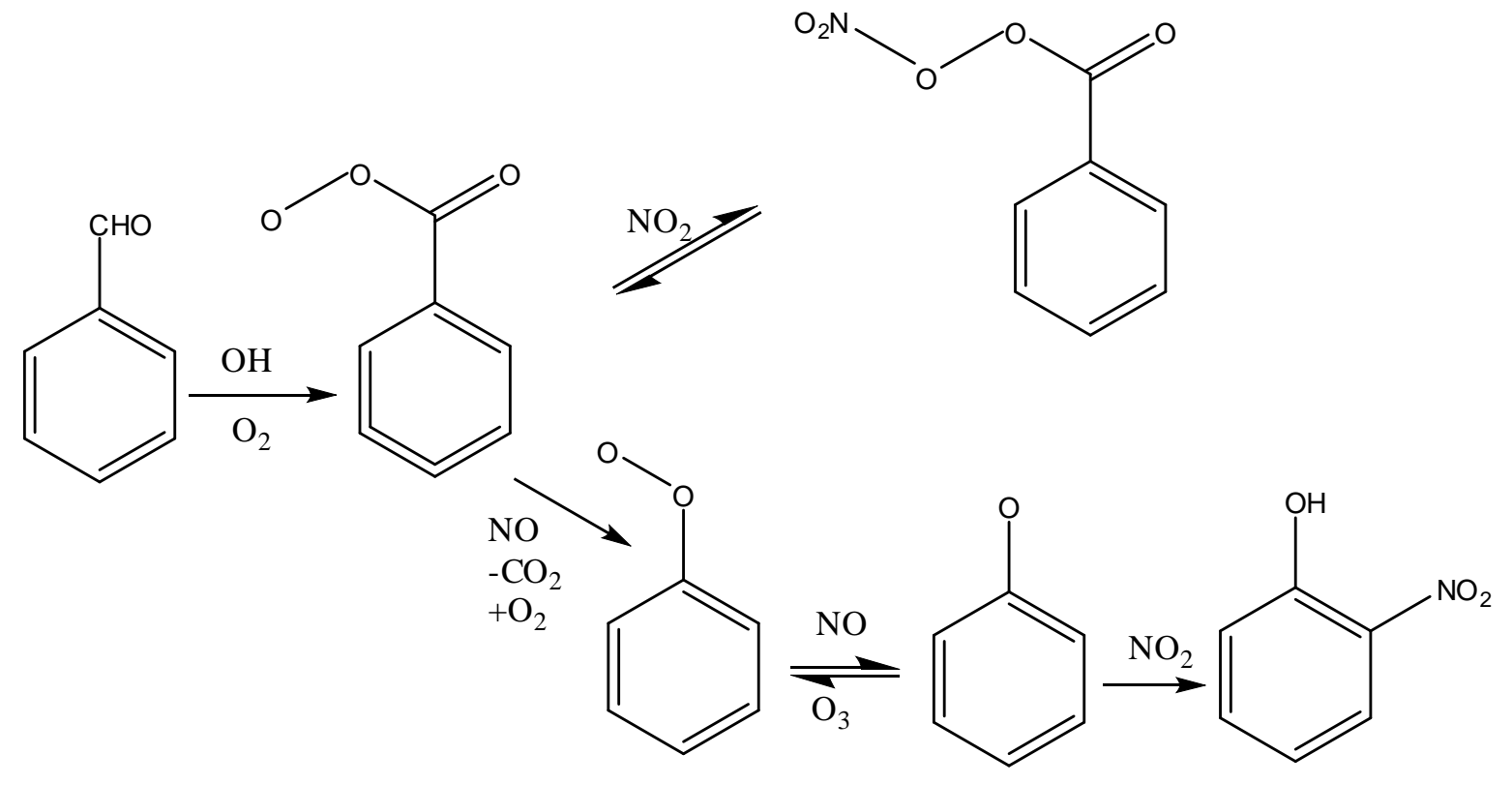

Scheme 4. Atmospheric degradation of benzaldehyde (adapted from Calvert et al. ${ }^{8}$ )

Unsaturated Aldehydes: Unsaturated aldehydes are very reactive towards atmospheric oxidants, photolysis is likely a minor loss mechanism. ${ }^{82}$ Removal by $\mathrm{O}_{3}$ is less significant than by $\mathrm{OH}$ and $\mathrm{NO}_{3}$ for the mono-unsaturated aldehydes but is important for the dienals. The rate constants for reactions of $\mathrm{OH}$ and $\mathrm{NO}_{3}$ with mono-unsaturated aldehydes are in the ranges $k_{\mathrm{OH}} \approx(2-6) \times 10^{-11}$ and $k_{\mathrm{NO} 3} \approx(1-500) \times 10^{-15} \mathrm{~cm}^{3}$ molecule $\mathrm{s}^{-1} \mathrm{~s}^{-1}$, respectively, depending on the structure and size of the molecule. The lifetimes of the mono-unsaturated aldehydes with respect to reaction with $\mathrm{OH}$ and $\mathrm{NO}_{3}$ range from hours to 1 day. The dienals are even more reactive than the monounsaturated aldehydes, $k_{\mathrm{OH}} \approx 1 \times 10^{-10}$ and $k_{\mathrm{NO} 3} \approx 2 \times 10^{-12} \mathrm{~cm}^{3}$ molecule ${ }^{-1} \mathrm{~s}^{-1}$, respectively. Their 
lifetimes with respect to reactions with $\mathrm{OH}$ and $\mathrm{NO}_{3}$ are below $1 \mathrm{~h}$ while that with respect to $\mathrm{O}_{3}$ is of the order of hours.

The reactions of $\mathrm{OH}$ and $\mathrm{NO}_{3}$ with unsaturated aldehydes proceed by both $\mathrm{H}$-atom abstraction from the $-\mathrm{CHO}$ group and addition to the $>\mathrm{C}=\mathrm{C}<$ double bonds. $\mathrm{H}$-atom abstraction from the $\mathrm{CHO}$ group, in the presence of NOx, leads to the formation of peroxyacylnitrates, $\mathrm{RC}(\mathrm{O}) \mathrm{O}_{2} \mathrm{NO}_{2}$, such as peroxyacryloyl nitrate from acrolein, peroxycrotonoyl nitrate from crotonaldehyde, and peroxymethacryloyl nitrate from methacrolein. ${ }^{83-87}$ As described above, peroxyacylnitrates serve as reservoirs for $\mathrm{NO}_{\mathrm{x}}$ and can transport $\mathrm{NO}_{\mathrm{x}}$ over long distances. The other products reported in the oxidation of unsaturated aldehydes are radicals and short-chain carbonyls which may play an important role in ozone formation as shown in scheme 3 for formaldehyde. 
Table 5: Kinetic data and estimated atmospheric lifetimes for aldehydes with respect to photolysis and gas-phase reactions with OH, $\mathrm{O}_{3}$, and $\mathrm{NO}_{3}$.

\begin{tabular}{|c|c|c|c|c|c|c|c|c|c|}
\hline Compound & $\mathrm{k}_{\mathrm{OH}}\left(\times 10^{-12}\right)^{\mathrm{a}}$ & $\tau_{\mathrm{OH}}{ }^{b}$ & $k_{\mathrm{O} 3}\left(\times 10^{-18}\right)^{\mathrm{a}}$ & $\tau_{\mathrm{O} 3}{ }^{b}$ & $k_{\mathrm{NO} 3}\left(\times 10^{-14}\right)^{\mathrm{a}}$ & $\tau_{\mathrm{NO} 3}{ }^{b, c}$ & $\mathrm{~J}^{\mathrm{d}}\left(\mathrm{s}^{-1}\right)$ & $\tau_{h v}{ }^{\mathrm{e}}$ & $\tau$ (total lifetime) \\
\hline \multicolumn{10}{|c|}{$\begin{array}{l}\text { Acyclic and Cyclic } \\
\text { aldehydes }\end{array}$} \\
\hline $\mathrm{HCHO}$ & 8.5 & $1.4 \mathrm{~d}$ & - & - & 0.058 & $13.3 \mathrm{~d}$ & $9.02 \times 10^{-5}$ & $11 \mathrm{~h}$ & $8 \mathrm{~h}$ \\
\hline $\mathrm{CH}_{3} \mathrm{CHO}$ & 15.3 & $7.3 \mathrm{~h}$ & - & - & 0.257 & $3 \mathrm{~d}$ & $7.31 \times 10^{-6}$ & $6.9 \mathrm{~d}$ & $6.4 \mathrm{~h}$ \\
\hline $\mathrm{CH}_{3} \mathrm{CH}_{2} \mathrm{CHO}$ & 18.7 & $5.9 \mathrm{~h}$ & - & - & 0.63 & $1.2 \mathrm{~d}$ & $1.18 \times 10^{-5}$ & $3.9 \mathrm{~d}$ & $4.6 \mathrm{~h}$ \\
\hline $\mathrm{n}-\mathrm{C}_{3} \mathrm{H}_{7} \mathrm{CHO}$ & 23.7 & $4.7 \mathrm{~h}$ & - & - & 1.14 & $8.1 \mathrm{~d}$ & $1.98 \times 10^{-5}$ & $2.3 \mathrm{~d}$ & $4.2 \mathrm{~h}$ \\
\hline$\left(\mathrm{CH}_{3}\right)_{2} \mathrm{CHCHO}$ & 25.6 & $4.3 \mathrm{~h}$ & 0.039 & $0.8 \mathrm{y}$ & 1.17 & $7.9 \mathrm{~h}$ & $5.91 \times 10^{-5}$ & $15 \mathrm{~h}$ & $2.3 \mathrm{~h}$ \\
\hline $\mathrm{n}-\mathrm{C}_{4} \mathrm{H}_{9} \mathrm{CHO}$ & 26.6 & $4.2 \mathrm{~h}$ & - & - & 1.62 & $5.7 \mathrm{~h}$ & $1.80 \times 10^{-5}$ & $2.5 \mathrm{~d}$ & $2.3 \mathrm{~h}$ \\
\hline $\mathrm{CH}_{3} \mathrm{CH}_{2} \mathrm{CH}\left(\mathrm{CH}_{3}\right) \mathrm{CHO}$ & 33.3 & $3.3 \mathrm{~h}$ & - & - & 2.67 & $3.5 \mathrm{~h}$ & - & - & $1.7 \mathrm{~h}$ \\
\hline$\left(\mathrm{CH}_{3}\right)_{2} \mathrm{CHCH}_{2} \mathrm{CHO}$ & 25.9 & $4.3 \mathrm{~h}$ & - & - & 2.19 & $4.2 \mathrm{~h}$ & $1.81 \times 10^{-5}$ & $2.4 \mathrm{~d}$ & $2 \mathrm{~h}$ \\
\hline$\left(\mathrm{CH}_{3}\right)_{3} \mathrm{CCHO}$ & 26.4 & $4.2 \mathrm{~h}$ & - & - & 2.4 & $3.9 \mathrm{~h}$ & $2.4 \times 10^{-5}$ & $1.9 \mathrm{~d}$ & $1.9 \mathrm{~h}$ \\
\hline $\mathrm{n}-\mathrm{C}_{5} \mathrm{H}_{11} \mathrm{CHO}$ & 28.5 & $4.3 \mathrm{~h}$ & - & - & 1.61 & $5.8 \mathrm{~h}$ & $2.41 \times 10^{-5}$ & $1.9 \mathrm{~d}$ & $2 / 3 \mathrm{~h}$ \\
\hline 2-Methylpentanal & 33 & $3.4 \mathrm{~h}$ & - & - & 2.79 & $3.3 \mathrm{~h}$ & - & - & $1.7 \mathrm{~h}$ \\
\hline
\end{tabular}




\begin{tabular}{|c|c|c|c|c|c|c|c|c|c|}
\hline 3-Methypentanal & 29.1 & $3.8 \mathrm{~h}$ & - & - & 2.5 & $3.7 \mathrm{~h}$ & - & - & $1.9 \mathrm{~h}$ \\
\hline 4-Methylpentanal & 26.3 & $4.2 \mathrm{~h}$ & - & - & 1.74 & $5.3 \mathrm{~h}$ & - & - & $2.3 \mathrm{~h}$ \\
\hline 3,3-Dimethylpentanal & 21.4 & $5.2 \mathrm{~h}$ & - & - & 1.77 & $5.2 \mathrm{~h}$ & - & - & $2.6 \mathrm{~h}$ \\
\hline 2-Ethylbutanal & 40.2 & $2.8 \mathrm{~h}$ & - & - & 4.63 & $2 \mathrm{~h}$ & - & - & $1.2 \mathrm{~h}$ \\
\hline n-Heptanal & 29.6 & $3.8 \mathrm{~h}$ & - & - & 1.97 & $4.7 \mathrm{~h}$ & $1.13 \times 10^{-5}$ & $3.3 \mathrm{~d}$ & $2 \mathrm{~h}$ \\
\hline 2,3-Dimethylpentanal & 42 & $2.7 \mathrm{~h}$ & - & - & - & - & - & - & $2.7 \mathrm{~h}$ \\
\hline n-Octanal & $30 *$ & $3.7 \mathrm{~h}$ & - & - & 1.8 & $5.1 \mathrm{~h}$ & - & - & $2.1 \mathrm{~h}$ \\
\hline n-Nonanal & 32 & $3.5 \mathrm{~h}$ & - & - & 2.0 & $4.6 \mathrm{~h}$ & - & - & $2 \mathrm{~h}$ \\
\hline n-Decanal & $30 *$ & $3.7 \mathrm{~h}$ & - & - & 2.2 & $4.2 \mathrm{~h}$ & - & - & $2 \mathrm{~h}$ \\
\hline Cyclopropanecarbaldehyde & 21 & $5.3 \mathrm{~h}$ & - & - & 0.63 & $1.2 \mathrm{~d}$ & - & - & $4.5 \mathrm{~h}$ \\
\hline Cyclobutanecarbaldehyde & 26.3 & $4.2 \mathrm{~h}$ & - & - & 2.06 & $4.5 \mathrm{~h}$ & - & - & $2.2 \mathrm{~h}$ \\
\hline Cyclopentanecarbaldehyde & 31.3 & $3.6 \mathrm{~h}$ & - & - & 2.64 & $3.5 \mathrm{~h}$ & - & - & $1.8 \mathrm{~h}$ \\
\hline Cyclohexanecarbaldehyde & 37 & $3 \mathrm{~h}$ & - & - & 3.31 & $2.8 \mathrm{~h}$ & - & - & $1.5 \mathrm{~h}$ \\
\hline \multicolumn{10}{|l|}{ Hydroxyaldehydes } \\
\hline $\mathrm{HOCH}_{2} \mathrm{CHO}$ & 8.3 & $33.5 \mathrm{~h}$ & - & - & - & - & $1.48 \times 10^{-5}$ & $3.4 \mathrm{~d}$ & \\
\hline $\mathrm{CH}_{3} \mathrm{CH}(\mathrm{OH}) \mathrm{CHO}$ & 17 & $6.5 \mathrm{~h}$ & - & - & - & - & - & - & $6.5 \mathrm{~h}$ \\
\hline $\mathrm{HOCH}_{2} \mathrm{CH}_{2} \mathrm{CHO}$ & 19.9 & $5.6 \mathrm{~h}$ & - & - & - & - & - & - & $5.6 \mathrm{~h}$ \\
\hline $\mathrm{CH}_{3} \mathrm{CH}_{2} \mathrm{CH}(\mathrm{OH}) \mathrm{CHO}$ & 23.7 & $4.7 \mathrm{~h}$ & - & - & - & - & - & - & $4.7 \mathrm{~h}$ \\
\hline $\mathrm{CH}_{3} \mathrm{CH}(\mathrm{OH}) \mathrm{CH}_{2} \mathrm{CHO}$ & 29.5 & $3.8 \mathrm{~h}$ & - & - & - & - & - & - & $3.8 \mathrm{~h}$ \\
\hline
\end{tabular}




\begin{tabular}{|c|c|c|c|c|c|c|c|c|c|}
\hline$\left(\mathrm{CH}_{3}\right)_{2} \mathrm{C}(\mathrm{OH}) \mathrm{CHO}$ & 14 & $7.4 \mathrm{~h}$ & - & - & - & - & - & - & $7.4 \mathrm{~h}$ \\
\hline \multicolumn{10}{|l|}{ Unsaturated aldehydes } \\
\hline $\mathrm{CH}_{2}=\mathrm{CHCHO}$ & 21.6 & $5.1 \mathrm{~h}$ & 0.29 & $40 \mathrm{~d}$ & 0.115 & $6.7 \mathrm{~d}$ & $1.42 \times 10^{-6}$ & $27 \mathrm{~d}$ & $4.9 \mathrm{~h}$ \\
\hline $\mathrm{CH}_{3} \mathrm{CH}=\mathrm{CHCHO}$ & 36 & $3.1 \mathrm{~h}$ & 1.39 & $8.3 \mathrm{~d}$ & 1.0 & $9.3 \mathrm{~h}$ & $6.61 \times 10^{-6}$ & $5.9 \mathrm{~d}$ & $2.3 \mathrm{~h}$ \\
\hline $\mathrm{CH}_{2}=\mathrm{C}\left(\mathrm{CH}_{3}\right) \mathrm{CHO}$ & 32 & $3.5 \mathrm{~h}$ & 1.12 & $8.3 \mathrm{~d}$ & 0.34 & $2.2 \mathrm{~h}$ & - & - & $1.3 \mathrm{~h}$ \\
\hline E-2-Pentenal & 44 & $2.5 \mathrm{~h}$ & 1.59 & $7.3 \mathrm{~d}$ & 2.9 & $3.2 \mathrm{~h}$ & - & - & $1.4 \mathrm{~h}$ \\
\hline 3-Methyl-2-butenal & - & - & 1.82 & $6.4 \mathrm{~d}$ & - & - & - & - & $6.4 \mathrm{~d}$ \\
\hline E-2-Methyl-2-butenal & - & - & 5.3 & $2.2 \mathrm{~d}$ & - & - & - & - & $2.2 \mathrm{~d}$ \\
\hline E-2-Hexenal & 43 & $2.6 \mathrm{~h}$ & 2.1 & $5.5 \mathrm{~d}$ & 3.3 & $2.8 \mathrm{~h}$ & - & - & $1.3 \mathrm{~h}$ \\
\hline E-2-Heptenal & 44 & $2.5 \mathrm{~h}$ & - & - & 9.6 & $58 \mathrm{~min}$ & - & - & $42 \mathrm{~min}$ \\
\hline Z-4-Heptenal & - & - & - & - & 26 & $21 \mathrm{~min}$ & - & - & $21 \mathrm{~min}$ \\
\hline 4-Methylenhex-5-enal & 155 & $43 \mathrm{~min}$ & 15 & $18.5 \mathrm{~h}$ & 48 & $12 \mathrm{~min}$ & - & - & $9.3 \mathrm{~min}$ \\
\hline $\begin{array}{l}\text { 3-Z-4-Methylhexa-3,5- } \\
\text { dienal }\end{array}$ & 161 & $41 \mathrm{~min}$ & 43.6 & $6.4 \mathrm{~h}$ & 220 & $3 \min$ & - & - & $2.8 \mathrm{~min}$ \\
\hline $\begin{array}{l}\text { 3-E-4-Methylhexa-3,5- } \\
\text { dienal }\end{array}$ & 252 & $26 \mathrm{~min}$ & 56.6 & $4.9 \mathrm{~h}$ & 180 & $3 \mathrm{~min}$ & - & - & $2.7 \mathrm{~min}$ \\
\hline \multicolumn{10}{|c|}{$\begin{array}{l}\text { Dialdehydes and } \\
\text { ketoaldehydes }\end{array}$} \\
\hline $\mathrm{HC}(\mathrm{O}) \mathrm{CHO}$ & 9 & $25.7 \mathrm{~h}$ & $<0.003$ & $10.7 \mathrm{y}$ & - & - & $1.40 \times 10^{-4}$ & $6.5 \mathrm{~h}$ & $5.2 \mathrm{~h}$ \\
\hline
\end{tabular}




\begin{tabular}{|c|c|c|c|c|c|c|c|c|c|}
\hline $\mathrm{CH}_{3} \mathrm{C}(\mathrm{O}) \mathrm{CHO}$ & 13 & $8.6 \mathrm{~h}$ & $<0.006$ & $>5.4 \mathrm{y}$ & - & - & $1.45 \times 10^{-4}$ & $5.7 \mathrm{~h}$ & $3.4 \mathrm{~h}$ \\
\hline \multicolumn{10}{|l|}{ Unsaturated dialdehydes } \\
\hline Z-Butenedial & 57 & $2 \mathrm{~h}$ & - & - & - & - & $1.20 \times 10^{-3}$ & $0.7 \mathrm{~h}$ & $0.5 \mathrm{~h}$ \\
\hline E-Butenedial & $\geq 26$ & $<4.3 \mathrm{~h}$ & - & - & - & - & $1.20 \times 10^{-3}$ & $0.7 \mathrm{~h}$ & $<0.6 \mathrm{~h}$ \\
\hline E-,E-2,4-Hexandienedial & 82 & $1.4 \mathrm{~h}$ & $<10$ & $>1 \mathrm{~d}$ & - & - & - & - & $1.4 \mathrm{~h}$ \\
\hline E-,Z-2,4-Hexandienedial & 92 & $1.2 \mathrm{~h}$ & - & - & - & - & - & - & $1.2 \mathrm{~h}$ \\
\hline $\begin{array}{l}\text { E-,E-2-Methyl 2,4- } \\
\text { Hexandienedial }\end{array}$ & 118 & $56 \mathrm{~min}$ & - & - & - & - & - & - & $56 \mathrm{~min}$ \\
\hline E-/Z-4-Oxo-2-pentenal & 61 & $1.8 \mathrm{~h}$ & - & - & - & - & - & - & $1.8 \mathrm{~h}$ \\
\hline \multicolumn{10}{|l|}{ Aromatic aldehydes } \\
\hline $\mathrm{C}_{6} \mathrm{H}_{5} \mathrm{CHO}$ & 12.6 & $8.8 \mathrm{~h}$ & - & - & 0.4 & $1.9 \mathrm{~d}$ & $3.12 \times 10^{-4}$ & $4.6 \mathrm{~h}$ & $2.8 \mathrm{~h}$ \\
\hline$o$-Tolualdehyde & 18.9 & $5.9 \mathrm{~h}$ & - & - & $0.98^{f}$ & $9.5 \mathrm{~h}$ & $2 \times 10^{-4 g}$ & $2 \mathrm{~h}^{\mathrm{g}}$ & $1.3 \mathrm{~h}$ \\
\hline$m$-Tolualdehyde & 16.8 & $6.6 \mathrm{~h}$ & - & - & $0.95^{\mathrm{f}}$ & $9.8 \mathrm{~h}$ & - & - & $3.9 \mathrm{~h}$ \\
\hline$p$-Tolualdehyde & 16.8 & $6.6 \mathrm{~h}$ & - & - & $0.95^{\mathrm{f}}$ & $9.8 \mathrm{~h}$ & - & - & $3.9 \mathrm{~h}$ \\
\hline 2,3-Dimethylbenzaldehyde & 25.5 & $4.4 \mathrm{~h}$ & - & - & - & - & - & - & $4.4 \mathrm{~h}$ \\
\hline 2,4-Dimethylbenzaldehyde & 31.2 & $3.6 \mathrm{~h}$ & - & - & - & - & - & - & $3.6 \mathrm{~h}$ \\
\hline 2,5-Dimethylbenzaldehyde & 31.5 & $3.5 \mathrm{~h}$ & - & - & - & - & - & - & $3.5 \mathrm{~h}$ \\
\hline 2,6-Dimethylbenzaldehyde & 30.3 & $3.7 \mathrm{~h}$ & - & - & - & - & - & - & $3.7 \mathrm{~h}$ \\
\hline 3,4-Dimethylbenzaldehyde & 23.6 & $4.7 \mathrm{~h}$ & - & - & - & - & - & - & $4.7 \mathrm{~h}$ \\
\hline
\end{tabular}




\begin{tabular}{|c|c|c|c|c|c|c|c|c|c|}
\hline 3,5-Dimethylbenzaldehyde & 27.8 & $4 \mathrm{~h}$ & - & - & - & - & - & - & $4 \mathrm{~h}$ \\
\hline $\mathrm{C}_{6} \mathrm{H}_{5} \mathrm{CHCHCHO}$ & 48 & $2.3 \mathrm{~h}$ & 2.3 & $5 \mathrm{~d}$ & 1.9 & $4.9 \mathrm{~h}$ & - & - & $1.5 \mathrm{~h}$ \\
\hline 2-Formylbenzaldehyde & 23 & $4.8 \mathrm{~h}$ & - & - & - & - & - & - & $4.8 \mathrm{~h}$ \\
\hline 2-Acetylbenzaldehyde & 17 & $6.5 \mathrm{~h}$ & - & - & - & - & - & - & $6.5 \mathrm{~h}$ \\
\hline Pinonaldehyde & 42 & $2.7 \mathrm{~h}$ & $<0.023$ & $>1.4 \mathrm{y}$ & 2 & $4.6 \mathrm{~h}$ & $1.41 \times 10^{-5}$ & $3.2 \mathrm{~d}$ & $1.7 \mathrm{~h}$ \\
\hline Caronaldehyde & 50 & $2.2 \mathrm{~h}$ & - & - & 2.5 & $3.7 \mathrm{~h}$ & - & - & $1.4 \mathrm{~h}$ \\
\hline $\begin{array}{l}\text { 3,7-dimethyl-6-octen-1-al } \\
\text { (Citronellal) }\end{array}$ & 151 & $44 \min$ & 350 & $48 \min$ & 2.5 & $3.7 \mathrm{~h}$ & - & - & $21 \mathrm{~min}$ \\
\hline
\end{tabular}

* Estimated

${ }^{\mathrm{a}} k_{\mathrm{OH}}, k_{\mathrm{NO} 3}$ and $k_{\mathrm{O} 3}$ : rate constants of the reactions with $\mathrm{OH}, \mathrm{NO}_{3}$ radicals and $\mathrm{O}_{3}$ in $\mathrm{cm}^{3}$ molecule ${ }^{-1} \mathrm{~s}^{-1}$ at $298 \mathrm{~K}$ and 1 bar, and photolysis rates data taken from Calvert et al. ${ }^{8}$

${ }^{\mathrm{b}}$ Lifetimes estimated by $\tau_{\mathrm{X}}=1 / k_{x}[\mathrm{X}]$, where $k$ is the rate constant for reaction of the OVOC with oxidants and [X] is the oxidant concentration; $[\mathrm{OH}]=10^{6}$ (24-hr average) for OVOCs with lifetimes > 1 day or $2.5 \times 10^{6}$ (typical day-time concentration) for OVOCs with lifetimes $<1$ day, $\left[\mathrm{O}_{3}\right]=10^{12}\left(24-\mathrm{hr}\right.$ average), and $\left[\mathrm{NO}_{3}\right]=3 \times 10^{9}$ molecule $\mathrm{cm}^{-3}$ (night-time value in polluted urban 
environments). Oxidant concentrations vary in time and space, the atmospheric lifetimes of OVOCs emitted at a particular place and time could be longer, or shorter, than the representative values listed above.

${ }^{c} \mathrm{NO}_{3}$ radical concentrations during the day-time are very low, lifetimes exceeding 12 hours calculated using the night-time value for polluted urban areas have been multiplied by a factor of 2 to facilitate comparison with lifetimes calculated using 24-hour average $[\mathrm{OH}]$ values.

\section{${ }^{\mathrm{d}}$ Overhead sun.}

${ }^{\mathrm{e}}$ photolysis lifetimes evaluated for $40^{\circ} \mathrm{N}$ latitude, $298 \mathrm{~K}, 0.5 \mathrm{~km}$ altitude, using average $\mathrm{J}$ value during 24 hour diurnal cycle for equinox (Mar. 22 or Sep 22).

${ }^{\mathrm{f}}$ Clifford et al. ${ }^{88} ;{ }^{\mathrm{g}}$ Clifford et al. ${ }^{89}$ 


\subsection{Ketones}

Ketones are emitted directly to the atmosphere or produced in-situ. They have anthropogenic and natural sources. They are used in a number of chemical industries as solvent or/intermediates. Atmospheric chemical transformation of other VOCs constitutes the source of ketones in the atmosphere. Acetone, one of the most important atmospheric ketones is produced in-situ from a number of anthropogenic and natural VOCs. Other ketones such as hydroxyketones are formed in the oxidation of alkanes and alkane diols. ${ }^{90-91}$ Hydroxyacetone is formed in the tropospheric oxidation of methacrolein which is itself a primary product of the degradation of isoprene. The atmospheric degradation of isoprene leads also to methyl vinyl ketone. The destruction of aromatic compounds in the atmosphere forms significant yields of a variety of dicarbonyls and unsaturated dicarbonyls. Butanedione is formed in the oxidation of o-xylene via a bridged bicyclic peroxy radical. Butanedione is also formed in the oxidation of methyl ethyl ketone under low NOx conditions via peroxy-peroxy radical reactions.

Aliphatic ketones, hydroxyketones, dicarbonyls cyclic and aromatic ketones: The main loss processes of ketones from the atmosphere are photolysis and reaction with $\mathrm{OH}$ radicals. Reactions of $\mathrm{O}_{3}$ and $\mathrm{NO}_{3}$ with saturated ketones are negligible under atmospheric conditions.

Ketones absorb quite strongly in the actinic region but their photolysis quantum yields are typically small for the pressures in the lower troposphere. ${ }^{92-94}$ Photolysis is a more important 
removal process at higher altitudes. Acetone, one of the most important ketones in the atmosphere, is removed predominately by reaction with $\mathrm{OH}$ at the surface with photolysis making a more important contribution at higher altitude. ${ }^{95-97}$ The lifetimes for photodissociation of ketones in the lower troposphere with an overhead sun are of the order of days to weeks (e.g., 14-22 days for acetone, $\approx 2.5$ days for butanone, 4-7 days for 2-pentanone and 1-8 days for 2hexanone). ${ }^{8}$ The photolysis of ketones is a substantial source of radicals in the atmosphere.

The rate constants for reactions of $\mathrm{OH}$ with ketones are larger than those with the corresponding alkanes. The presence of the carbonyl group deactivates the H-atom at the $\alpha$-position (attached to the carbon atom adjacent to the carbonyl group) but activates the hydrogen atoms at the $\beta$ position. ${ }^{98-99}$ The difference increases to up to a factor $\approx 3$ for the large ketones and the corresponding alkanes such as for 4-methyl-2-pentanone $\left(\mathrm{CH}_{3} \mathrm{C}(\mathrm{O}) \mathrm{CH}_{2} \mathrm{CH}\left(\mathrm{CH}_{3}\right)_{2}\right)$ and 2methylpentane $\left(\mathrm{CH}_{3} \mathrm{CH}_{2} \mathrm{CH}_{2} \mathrm{CH}\left(\mathrm{CH}_{3}\right)_{2}\right)$ for which the rate constants are $12.8 \times 10^{-12}$ and $5.26 \times 10^{-}$ $12 \mathrm{~cm}^{3}$ molecule $\mathrm{s}^{-1}$ at $298 \mathrm{~K}$, respectively. ${ }^{8,41}$ The rate constants for $\mathrm{OH}$ reactions with ketones are in the range $1.8 \times 10^{-13}$ for acetone to $2.5 \times 10^{-11}$ for 2,6-dimethyl-4-heptanone implying lifetimes with respect to $\mathrm{OH}$ of two months to a few hours depending on the structure of the molecule. $^{8}$

The reaction proceeds via an $\mathrm{H}$-atom abstraction, preferentially from the $\beta$-position if available. The $\mathrm{OH}$-initiated oxidation of acetone in the presence of NO in air has been shown to form the 
acetonoxy radical $\left(\mathrm{CH}_{3} \mathrm{C}(\mathrm{O}) \mathrm{CH}_{2} \mathrm{O}\right)$ which decomposes rapidly under atmospheric conditions to form $\mathrm{HCHO}$ and $\mathrm{CH}_{3} \mathrm{CO} .{ }^{100}$ This reaction has been suggested to be an important source of formaldehyde in the upper troposphere.

The reaction of $\mathrm{OH}$ with larger ketones occurs by $\mathrm{H}$-atom abstraction from various sites and leads to a variety of products such as simple aldehydes, dicarbonyls and hydroxydicarbonyls produced following reaction with $\mathrm{O}_{2}$, decomposition, and isomerization of the initially formed alkoxy radicals. As an example, the series of the potential first generation products arising from the chemistry of the alkoxy radicals produced in the $\mathrm{OH}$-initiated oxidation of 2-pentanone is given in Table 6 . The reaction of $\mathrm{OH}$ with 2-pentanone can proceed by 4 pathways, all involving $\mathrm{H}$-abstraction from the $\mathrm{C}-\mathrm{H}$ bonds and leading to formation of the corresponding alkoxy radicals in the presence of $\mathrm{O}_{2}$ and NO:

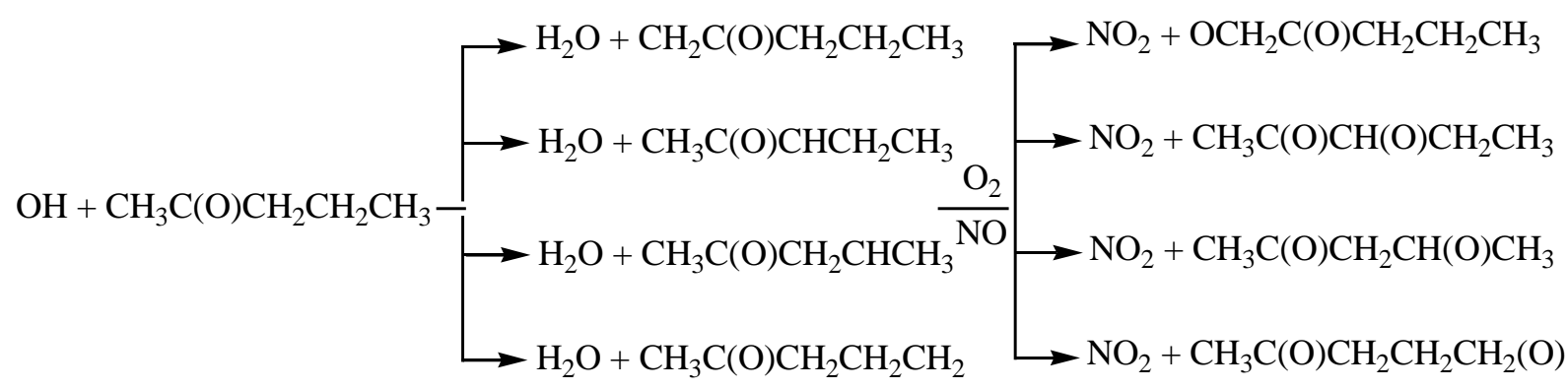

Organic nitrates may be also formed under high NOx conditions. The alkoxy radicals formed in the scheme shown above undergo reaction with $\mathrm{O}_{2}$, decomposition via $\mathrm{C}-\mathrm{C}$ bond fission, and isomerization. Table 6 summarises the reaction products from different alkoxy radicals. 
Table 6: Potential reaction products of the $\mathrm{OH}$-initiated oxidation of 2-pentanone (adapted from Atkinson et al.). ${ }^{101}$

\begin{tabular}{|c|c|c|}
\hline Alkoxy radicals & Products & Reaction channels \\
\hline $\mathrm{OCH}_{2} \mathrm{C}(\mathrm{O}) \mathrm{CH}_{2} \mathrm{CH}_{2} \mathrm{CH}_{3}$ & $\begin{array}{l}\mathrm{HC}(\mathrm{O}) \mathrm{C}(\mathrm{O}) \mathrm{CH}_{2} \mathrm{CH}_{2} \mathrm{CH}_{3} \\
\mathrm{HCHO}+\mathrm{CH}_{3} \mathrm{CH}_{2} \mathrm{CHO} \\
\mathrm{HOCH}_{2} \mathrm{C}(\mathrm{O}) \mathrm{CH}_{2} \mathrm{C}(\mathrm{O}) \mathrm{CH}_{3} \\
\mathrm{CH}_{3} \mathrm{CHO}+2 \quad 2 \mathrm{HCHO} \\
\mathrm{CH}_{3} \mathrm{CH}(\mathrm{OH}) \mathrm{CH}_{2} \mathrm{C}(\mathrm{O}) \mathrm{CHO}\end{array}$ & $\begin{array}{l}\text { reaction with } \mathrm{O}_{2} \\
\text { decomposition } \\
\text { isomerization }\end{array}$ \\
\hline $\mathrm{CH}_{3} \mathrm{C}(\mathrm{O}) \mathrm{CH}(\mathrm{O}) \mathrm{CH}_{2} \mathrm{CH}_{3}$ & $\begin{array}{l}\mathrm{CH}_{3} \mathrm{C}(\mathrm{O}) \mathrm{C}(\mathrm{O}) \mathrm{CH}_{2} \mathrm{CH}_{3} \\
\mathrm{CH}_{3} \mathrm{C}(\mathrm{O}) \mathrm{CHO}+\mathrm{CH}_{3} \mathrm{CHO} \text { and } \\
\mathrm{CH}_{3} \mathrm{CH}_{2} \mathrm{CHO}+\mathrm{HCHO}\end{array}$ & $\begin{array}{l}\text { reaction with } \mathrm{O}_{2} \\
\text { decomposition }\end{array}$ \\
\hline $\mathrm{CH}_{3} \mathrm{C}(\mathrm{O}) \mathrm{CH}_{2} \mathrm{CH}(\mathrm{O}) \mathrm{CH}_{3}$ & $\begin{array}{l}\mathrm{CH}_{3} \mathrm{C}(\mathrm{O}) \mathrm{CH}_{2} \mathrm{C}(\mathrm{O}) \mathrm{CH}_{3} \\
\mathrm{CH}_{3} \mathrm{CHO}+2 \mathrm{HCHO} \\
\mathrm{HOCH}_{2} \mathrm{C}(\mathrm{O}) \mathrm{CH}_{2} \mathrm{C}(\mathrm{O}) \mathrm{CH}_{3} \\
\mathrm{CH}_{3} \mathrm{CHO}+2 \mathrm{HCHO} \\
\end{array}$ & $\begin{array}{l}\text { reaction with } \mathrm{O}_{2} \\
\text { decomposition } \\
\text { isomerization }\end{array}$ \\
\hline $\mathrm{CH}_{3} \mathrm{C}(\mathrm{O}) \mathrm{CH}_{2} \mathrm{CH}_{2} \mathrm{CH}_{2}(\mathrm{O})$ & $\begin{array}{l}\mathrm{CH}_{3} \mathrm{C}(\mathrm{O}) \mathrm{CH}_{2} \mathrm{CH}_{2} \mathrm{CHO} \\
\mathrm{CH}_{3} \mathrm{C}(\mathrm{O}) \mathrm{CH}_{2} \mathrm{CHO}+\mathrm{HCHO}\end{array}$ & $\begin{array}{l}\text { reaction with } \mathrm{O}_{2} \\
\text { decomposition }\end{array}$ \\
\hline
\end{tabular}

Hydroxyketones are mainly removed from the atmosphere by reaction with $\mathrm{OH}$ radicals although photolysis can make an important contribution especially at high altitude. The lifetime of hydroxyacetone with respect to $\mathrm{OH}$ reaction is $\approx 3$ days and in the range 5-11 days for photolysis in the lower troposphere under an overhead sun. The atmospheric lifetimes of larger hydroxyketones are shorter because of their greater reactivity towards $\mathrm{OH}$ radicals $\left(k_{\mathrm{OH}} \approx 10^{-11}\right.$ $\mathrm{cm}^{3}$ molecule $\left.\mathrm{s}^{-1}\right)$.

Photolysis and reaction with $\mathrm{OH}$ radicals compete for the removal of diketones from the atmosphere although photolysis is the dominant loss process for the simplest diketone, 2,3- 
butanedione $\left(\mathrm{CH}_{3} \mathrm{C}(\mathrm{O}) \mathrm{C}(\mathrm{O}) \mathrm{CH}_{3}\right)$. The lifetime of $\mathrm{CH}_{3} \mathrm{C}(\mathrm{O}) \mathrm{C}(\mathrm{O}) \mathrm{CH}_{3}$ in the lower troposphere with respect to photolysis with an overhead sun is less than 4 hours while that with respect to reaction with $\mathrm{OH}$ radicals is $\approx 50$ days. For larger diketones, the reactions with $\mathrm{OH}$ radicals will be more significant. The general mechanism for the reaction of $\mathrm{OH}$ with diketones is expected to be mainly $\mathrm{H}$-atom abstraction leading to a series of shorter carbonyls.

Both $\mathrm{OH}$ reaction and photolysis play an important role in the atmospheric removal of cyclic and aromatic ketones depending on their size and structure. For example, lifetimes with respect to photolysis in the lower troposphere for cyclobutanone and 1,4-naphthoquinone are quite short, $\approx$ 10 hours and $\approx 2$ hours, respectively while those with respect to $\mathrm{OH}$ reaction are of the order of days. The contribution of $\mathrm{OH}$ reaction to the total atmospheric removal is more important for the larger cyclic and aromatic ketones but still of the order of a few days.

Unsaturated ketones: The atmospheric destruction of unsaturated ketones are mostly controlled by reaction with $\mathrm{OH}$ radicals for the short unsaturated ketones (e.g. methyl vinyl ketone, $\left.\mathrm{CH}_{3} \mathrm{C}(\mathrm{O}) \mathrm{CH}=\mathrm{CH}_{2}\right)$. The contributions of the reactions of $\mathrm{NO}_{3}$ and $\mathrm{O}_{3}$ become more important and may dominate for some larger species (6-methyl-5-hepten-2-one, $\left.\left.\mathrm{CH}_{3} \mathrm{C}(\mathrm{O}) \mathrm{CH}_{2} \mathrm{CH}_{2} \mathrm{CH}=\mathrm{C}\left(\mathrm{CH}_{3}\right)_{2}\right)\right)$. Lifetimes for photodissociation are relatively long, of the order of days while those with respect to reactions with $\mathrm{OH}, \mathrm{NO}_{3}$ and $\mathrm{O}_{3}$ are of the order of hours to minutes depending on the size and the structure of the species. The atmospheric oxidation of the 
unsaturated ketones produces a variety of products following the addition of the oxidant to the $>\mathrm{C}=\mathrm{C}<$ double bond. For example, formaldehyde, glycolaldehyde, methylglyoxal have been reported from the degradation of methyl vinyl ketone; propanal, and glycoladehyde in addition to minor yields of formaldehyde and 2-oxobutanal are expected from the degradation of ethyl vinyl ketone. ${ }^{8}$ The $\mathrm{NO}_{3}$-initiated oxidation of the larger unsaturated ketones is a source of nitrates.

Both photolysis and reaction with $\mathrm{OH}$ radicals are very effective loss processes for unsaturated dicarbonyls leading to lifetimes of a few hours. Their degradation leads to short chain carbonyls through decomposition although isomerization may also occur leading to cyclisation or rearrangement. ${ }^{102-105}$

\subsection{Esters}

Esters are emitted from natural and anthropogenic sources and are also formed in the atmosphere by the oxidation of ethers. Esters have low water solubility and following release partition into the gas-phase. Esters hydrolyze slowly and uptake into rain-cloud-sea water is generally of negligible importance. Esters do not absorb significantly at wavelengths greater than $240 \mathrm{~nm}$ and hence do not undergo photolysis in the lower atmosphere. The atmospheric chemistry of esters is dominated by their reaction with $\mathrm{OH}$ radicals. For unsaturated esters reactions with $\mathrm{O}_{3}$ 
and $\mathrm{NO}_{3}$ radicals also play a role. In the special case of highly fluorinated esters which are relatively unreactive towards $\mathrm{OH}$ radicals loss via hydrolysis can be an important atmospheric removal mechanism (see section IV.g). The available data concerning the atmospheric chemistry of esters has been the subject of a comprehensive recent review by Calvert et al. ${ }^{8}$ An overview of the atmospheric chemistry of esters is provided below, for details readers are encouraged to consult the detailed review by Calvert et al. ${ }^{8}$

As seen from Figure 9, the reactivity of esters towards $\mathrm{OH}$ radicals is substantially lower than for ethers of the same size. Small esters are less reactive than the corresponding alkanes, but for larger esters $\left(>\mathrm{C}_{5}\right)$ there is little, or no, discernable difference in reactivity with the corresponding alkanes. The ester functionality $-\mathrm{C}(\mathrm{O}) \mathrm{O}-$ in $\mathrm{R}_{1} \mathrm{C}(\mathrm{O}) \mathrm{OR}_{2}$ deactivates the $\mathrm{R}_{1}$ and $\mathrm{R}_{2}$ alkyl groups to which it is attached with the deactivation being most pronounced for the $\mathrm{R}_{1}$ group. ${ }^{8}$ The deactivation effect does not appear to extend beyond the first carbon atom in the $\mathrm{R}_{1}$ and $R_{2}$ groups and hence larger esters have reactivities which are similar to those of the corresponding alkanes (e.g., compare methyl hexanoate, $\mathrm{CH}_{3} \mathrm{OC}(\mathrm{O}) \mathrm{OC}_{5} \mathrm{H}_{11}$, and $n$-heptane, $\mathrm{C}_{7} \mathrm{H}_{16}$, in Figure 9). Combining the rate constants in Figure 9 with a diurnal average [OH] of $1 \times 10^{6} \mathrm{~cm}^{-3}$ gives lifetimes of esters ranging from 65 days for methyl formate to 1 day for $\mathrm{n}$ butyl-n-butyrate. 
As an example of the degradation mechanism of esters, scheme 4 shows a simplified mechanism for the oxidation of ethyl acetate. The majority $(\approx 94 \%)$ of the reaction with $\mathrm{OH}$ radicals proceeds via $\mathrm{H}$-atom abstraction from the $-\mathrm{CH}_{2}-$ group, the resulting alkyl radical adds $\mathrm{O}_{2}$ to give the peroxy radical $\mathrm{CH}_{3} \mathrm{C}(\mathrm{O}) \mathrm{OCH}(\mathrm{OO}) \mathrm{CH}_{3}$. Reaction with $\mathrm{NO}$ gives the alkoxy radical $\mathrm{CH}_{3} \mathrm{C}(\mathrm{O}) \mathrm{OCH}(\mathrm{OO}) \mathrm{CH}_{3}$. Alkoxy radicals of the general formula $\mathrm{R}_{1} \mathrm{C}(\mathrm{O}) \mathrm{OCH}(\mathrm{O}) \mathrm{R}_{2}$ generated following the $\mathrm{OH}$-radical initiated oxidation of esters have a novel decomposition route known as the $\alpha$-ester rearrangement which was first identified by Tuazon et al. ${ }^{106}$ The $\alpha$-ester rearrangement involves transfer of the hydrogen atom in $\mathrm{R}_{1} \mathrm{C}(\mathrm{O}) \mathrm{OCH}(\mathrm{O}) \mathrm{R}_{2}$ to give $\mathrm{R}_{1} \mathrm{C}(\mathrm{O}) \mathrm{OH}$ and the $\mathrm{R}_{2} \mathrm{CO}$ radical. In the case of ethyl acetate the products are $\mathrm{CH}_{3} \mathrm{C}(\mathrm{O}) \mathrm{OH}$ and $\mathrm{CH}_{3} \mathrm{CO}$ (acetyl radical) which are formed in essentially $100 \%$ yield. $^{8}$

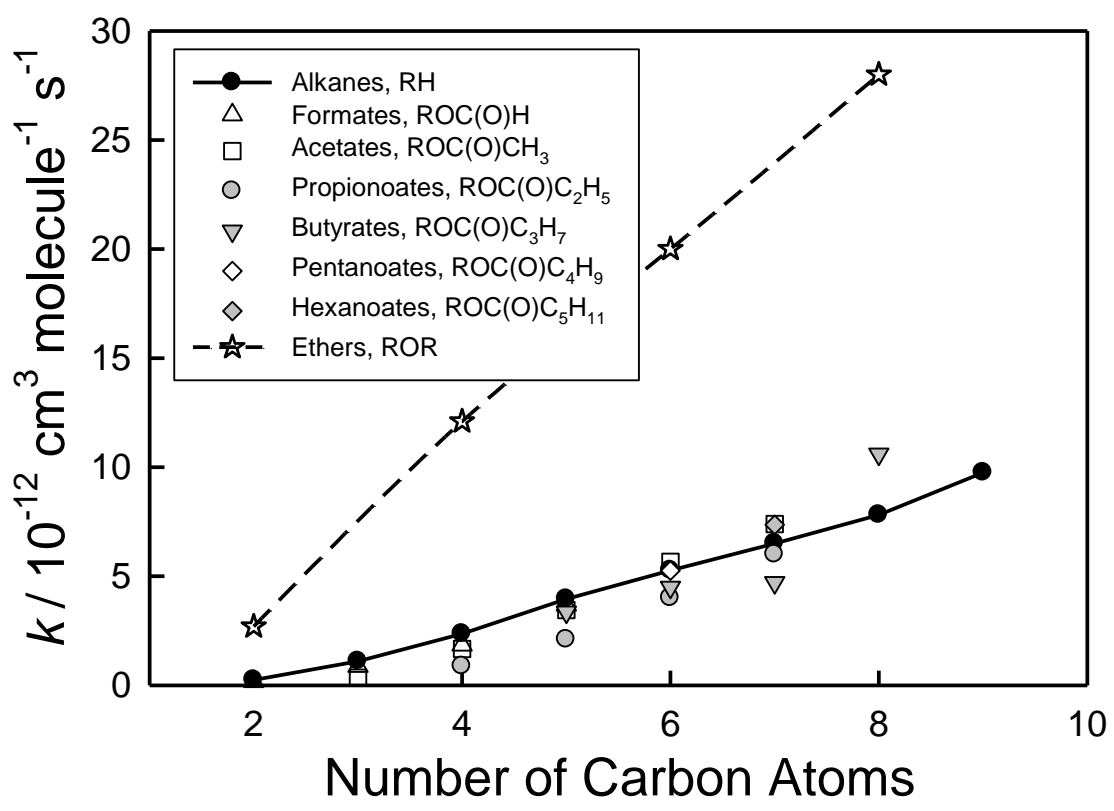


Figure 8. Rate constants at $298 \mathrm{~K}$ for reaction of $\mathrm{OH}$ radicals with esters, ethers, and $n$ -

alkanes. $^{8,107}$
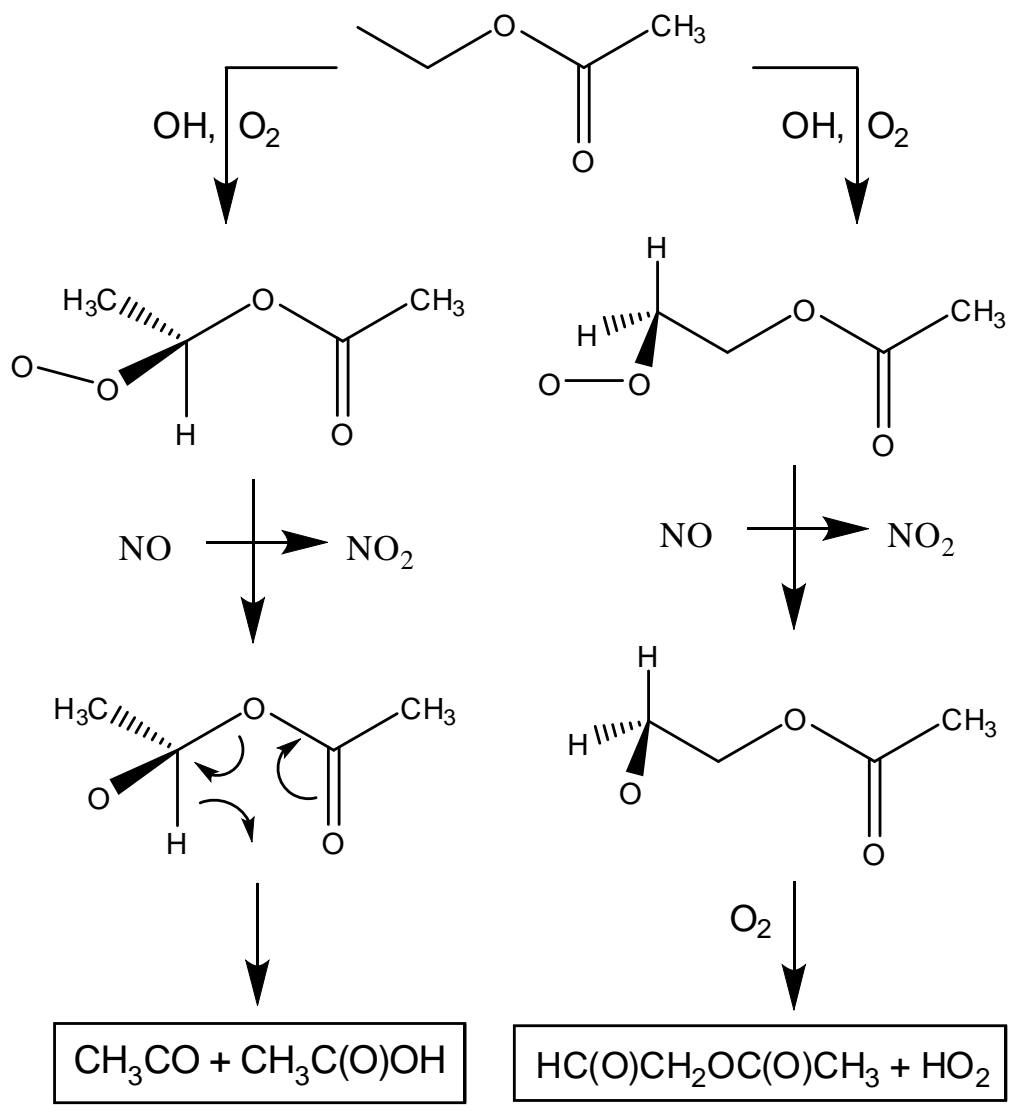

Scheme 4. Simplified mechanism of oxidation of ethyl acetate, adapted from Calvert et al. ${ }^{8}$

\subsection{Acids}

Carboxylic acids, $\mathrm{RC}(\mathrm{O}) \mathrm{OH}$, are emitted from natural and anthropogenic sources and are formed in the atmosphere following gas-phase reactions of ozone with alkenes ${ }^{108-111}$ and in 
condensed phase reactions in atmospheric aerosols ${ }^{112}$. The carboxylic acid chromophore does not absorb significantly at wavelengths greater than $250 \mathrm{~nm}$ and hence carboxylic acids generally do not undergo photolysis in the troposphere. An important exception is pyruvic acid $\left[\mathrm{CH}_{3} \mathrm{C}(\mathrm{O}) \mathrm{C}(\mathrm{O}) \mathrm{OH}\right]$. Substitution of the $-\mathrm{CH}_{3}$ group in acetone with the $-\mathrm{C}(\mathrm{O}) \mathrm{OH}$ group results in a red shift in absorption by approximately $75 \mathrm{~nm}$ and a photolysis lifetime for $\mathrm{CH}_{3} \mathrm{C}(\mathrm{O}) \mathrm{C}(\mathrm{O}) \mathrm{OH}$ of a few hours, or less, for overhead sun in the troposphere. ${ }^{8}$ Carboxylic acids are water soluble have low vapor pressures (especially dicarboxylic acids, see Figure 7), and are ubiquitous components of atmospheric aerosols.

The water solubility of carboxylic acids is an important factor in their atmospheric chemistry. The solubility of $\mathrm{RC}(\mathrm{O}) \mathrm{OH}$ in water can be represented by the equilibrium:

$$
R C(O) O H(\mathrm{~g}) \leftrightarrow R C(O) O H(\mathrm{aq})
$$

The equilibrium constant $[R C(O) O H(\mathrm{aq})] / \mathrm{p}_{R C(O) O H}$ is called the Henry's Law constant where $\mathrm{p}_{R C(O) O H}$ is the partial pressure (atm) of $\mathrm{RC}(\mathrm{O}) \mathrm{OH}$ in the gas phase. As defined here, it has units of $\mathrm{M}$ (moles liter $\left.{ }^{-1}\right) \mathrm{atm}^{-1}$ and is directly proportional to the solubility of $\mathrm{RC}(\mathrm{O}) \mathrm{OH}$. Dissociation of carboxylic acids in solution greatly decreases the concentration of the undissociated acid in solution and hence substantially increases the solubility of $\mathrm{RC}(\mathrm{O}) \mathrm{OH}$.

$$
\begin{aligned}
& \mathrm{RC}(\mathrm{O}) \mathrm{OH}_{(\mathrm{g})} \leftrightarrow \mathrm{RC}(\mathrm{O}) \mathrm{OH}_{(\mathrm{aq})} \\
& \mathrm{RC}(\mathrm{O}) \mathrm{OH}_{(\mathrm{aq})} \leftrightarrow \mathrm{RC}(\mathrm{O}) \mathrm{O}^{-}+\mathrm{H}^{+}
\end{aligned}
$$


The solubility of carboxylic acids can be calculated using an effective Henry's Law coefficient $\left(H^{*}\right)$ which is defined as $H^{*}=H \times\left(1+K_{\mathrm{a}} /\left[\mathrm{H}^{+}\right]\right)$, where $K_{\mathrm{a}}$ is the acid dissociation constant (see, for example, Brasseur et al., 1999). ${ }^{113}$ Temperature-dependent Henry's Law coefficients, $\mathrm{p} K_{\mathrm{a}}$ values $\left[\mathrm{p} K_{\mathrm{a}}=-\log _{10}\left(K_{\mathrm{a}}\right)\right]$, and effective Henry's Law coefficients evaluated for conditions representative of a typical cloud $(\mathrm{pH} \approx 5, T \approx 270 \mathrm{~K})$ are given in Table 7 for selected organic acids. As seen in Table 7, the solubility of carboxylic acids decreases with increasing size of the hydrophobic alkyl chain R. Seinfeld and Pandis ${ }^{114}$ have suggested that as a rough guide, species with Henry's Law constants below approximately $10^{3} \mathrm{M}$ atm $^{-1}$ will partition strongly into the atmospheric gas phase, and wet/dry deposition will probably not be of major importance. In contrast, compounds with Henry's Law constants above approximately $10^{6} \mathrm{M}$ atm ${ }^{-1}$ will partition strongly into atmospheric aerosols and wet/dry deposition may be an important atmospheric loss process. For the most water soluble gases the global average time scale for removal by wet deposition is limited by rain events and is approximately 1 week. ${ }^{113}$

For soluble carboxylic acids such as formic acid, effective scavenging into a typical cloud, occurs, and thus removal via rainout is anticipated on the timescale of about one week in the lower troposphere. ${ }^{113}$ While scavenging of the larger monocarboxylic acids by rain water will be less effective than for the small members of the series, inspection of Table 7 shows that 
the presence of additional oxygenated function groups in the molecule greatly increases the solubility of carboxylic acids (e.g., compare $\mathrm{CH}_{3} \mathrm{C}(\mathrm{O}) \mathrm{C}(\mathrm{O}) \mathrm{OH}$ and $\left.\mathrm{CH}_{3} \mathrm{CH}_{2} \mathrm{C}(\mathrm{O}) \mathrm{OH}\right)$.

Acyclic acids: Rate constants for reactions of $\mathrm{OH}$ radicals with acyclic carboxylic acids are shown in Figure 10. As expected, there is an increase in the reactivity of $\mathrm{RC}(\mathrm{O}) \mathrm{OH}$ species with increasing length of the $\mathrm{R}$ alkyl group. The smallest members of the series, formic and acetic acid, are significantly more reactive than the corresponding alkanes and methyl esters $\left(\mathrm{RC}(\mathrm{O}) \mathrm{OCH}_{3}\right)$. Interestingly, despite the substantial strength of the $\mathrm{RC}(\mathrm{O}) \mathrm{O}-\mathrm{H}$ bond $(460 \mathrm{~kJ}$ $\mathrm{mol}^{-1}$ ) the majority of reaction of $\mathrm{OH}$ radicals with formic and acetic acid proceeds via $\mathrm{H}$ abstraction to give the $\mathrm{RC}(\mathrm{O}) \mathrm{O}$ radical. The increase in reactivity from $\mathrm{CH}_{3} \mathrm{CH}_{2} \mathrm{C}(\mathrm{O}) \mathrm{OH}$ to $\mathrm{CH}_{3}\left(\mathrm{CH}_{2}\right)_{2} \mathrm{C}(\mathrm{O}) \mathrm{OH}$ is similar to that expected from the additional reactivity of a $-\mathrm{CH}_{2}-$ group in the alkanes. Combining the rate constants in Figure 10 with a diurnal average $[\mathrm{OH}]=1 \times 10^{6} \mathrm{~cm}^{-}$ ${ }^{3}$ gives lifetimes with respect to reaction with $\mathrm{OH}$ radicals for formic, acetic, $n$-propanoic, and $n$ butanoic acids of 26, 16, 10, and 6 days, respectively. For the smaller acids the atmospheric fate is dominated by incorporation into rain-cloud-fog water followed by wet deposition. For larger acids gas-phase reaction with $\mathrm{OH}$ radicals can be a competitive loss mechanism.

Dicarboxylic acids: Dicarboxylic acids are produced in small yields in the gas phase and can be generated from the condensed-phase oxidation of multi-functional species; for example, species such as glycolaldehyde $\left[\mathrm{HOCH}_{2} \mathrm{CHO}\right]$, glyoxal $[\mathrm{HC}(\mathrm{O}) \mathrm{CHO}]$, glycolic acid $\left[\mathrm{HOCH}_{2} \mathrm{C}(\mathrm{O}) \mathrm{OH}\right]$ 
or glyoxylic acid $[\mathrm{HC}(\mathrm{O}) \mathrm{C}(\mathrm{O}) \mathrm{OH}]$ can be converted to oxalic acid $[\mathrm{HOC}(\mathrm{O}) \mathrm{C}(\mathrm{O}) \mathrm{H}]$ in aqueous media. ${ }^{112}$ Dicarboxylic acids have very low vapor pressures, ${ }^{115-116}$ are highly soluble, ${ }^{117}$ and are ubiquitous components of organic aerosol and cloudwater. Dicarboxylic acids and their condensed phase by-products are removed from the atmosphere by heterogeneous processes (rainout, and aerosol wet and dry deposition) on a time scale of approximately 1 week. ${ }^{8}$

Unsaturated carboxylic acids and ketoacids: Unsaturated organic acids are produced as minor products in the ozonolysis of dienes. Acrylic $\left[\mathrm{CH}_{2}=\mathrm{CHC}(\mathrm{O}) \mathrm{OH}\right]$ and methacrylic acids $\left[\mathrm{CH}_{2}=\mathrm{CCH}_{3} \mathrm{C}(\mathrm{O}) \mathrm{OH}\right]$ are formed following reaction of ozone with isoprene. ${ }^{110}$ The dominant atmospheric fate of unsaturated carboxylic acids is reaction with $\mathrm{OH}$ radicals which occurs rapidly. Estimates of the atmospheric lifetimes for acrylic and methacrylic acid are 6 and 4 hours, respectively. The reaction occurs via $\mathrm{OH}$ addition to the $>\mathrm{C}=\mathrm{C}<$ double bond, addition of $\mathrm{O}_{2}$ to give a peroxy radical, reaction with $\mathrm{NO}$ to give the corresponding alkoxy radical which undergoes $\mathrm{C}-\mathrm{C}$ bond scission. The oxidation of methacrylic acid $\left[\mathrm{CH}_{2}=\mathrm{CCH}_{3} \mathrm{C}(\mathrm{O}) \mathrm{OH}\right]$ gives pyruvic acid $\left[\mathrm{CH}_{3} \mathrm{C}(\mathrm{O}) \mathrm{C}(\mathrm{O}) \mathrm{OH}\right]$. Pyruvic acid $\left[\mathrm{CH}_{3} \mathrm{C}(\mathrm{O}) \mathrm{C}(\mathrm{O}) \mathrm{OH}\right]$ reacts slowly with $\mathrm{OH}$ radicals $^{118}$ but undergoes rapid photolysis and has a lifetime of a few hours or less. ${ }^{8}$

Carboxylic acids derived from reactions of ozone with terpenes: The ozonolysis of terpenes generates a large number of multi-functional organic acids. ${ }^{108,111}$ These organic acids have extremely low vapor pressures (typically $\leq 10^{-4} \mathrm{~Pa}$ at $298 \mathrm{~K},{ }^{119}$ ) and partition into the condensed 
phase. With such low vapor pressures experimental studies of gas phase loss mechanisms are extremely difficult and have yet to be reported.

Table 7. Henry's Law constants $H(T)=H(298 \mathrm{~K}) \times\left[\exp (B \times((1 / T)-(1 / 298))], \mathrm{p} K_{\mathrm{a}}\right.$ values, and effective Henry's Law constants, $\mathrm{H}^{*}$, at $270 \mathrm{~K}$ and $\mathrm{pH}=5$ for selected acids.

\begin{tabular}{|c|c|c|c|c|}
\hline Acid & $\begin{array}{c}H \text { at } 298 \mathrm{~K} \\
\left(\mathrm{M} \operatorname{atm}^{-1}\right)\end{array}$ & $B(\mathbf{K})$ & $\mathrm{p} K_{\mathrm{a}}^{\mathrm{a}}$ & $\begin{array}{c}\mathrm{H}^{*}, 270 \mathrm{~K}, \mathrm{pH}=5 \\
\left(\mathrm{M} \text { atm }^{-1}\right)\end{array}$ \\
\hline Formic, $\mathrm{HC}(\mathrm{O}) \mathrm{OH}$ & $7.2 \times 10^{3 b}$ & $6100^{d}$ & 3.75 & $1.1 \times 10^{6}$ \\
\hline Acetic, $\mathrm{CH}_{3} \mathrm{C}(\mathrm{O}) \mathrm{OH}$ & $4.8 \times 10^{3}$ b & $6300^{d}$ & 4.76 & $1.2 \times 10^{5}$ \\
\hline Propanoic, $\mathrm{C}_{2} \mathrm{H}_{5} \mathrm{C}(\mathrm{O}) \mathrm{OH}$ & $5.7 \times 10^{3} \mathrm{c}$ & $6100^{e}$ & 4.86 & $1.1 \times 10^{5}$ \\
\hline$n$-Butanoic, $n-\mathrm{C}_{3} \mathrm{H}_{7} \mathrm{C}(\mathrm{O}) \mathrm{OH}$ & $4.7 \times 10^{3} \mathrm{c}$ & $6100^{\mathrm{e}}$ & 4.83 & $9.7 \times 10^{4}$ \\
\hline$n$-Pentanoic, $n-\mathrm{C}_{4} \mathrm{H}_{9} \mathrm{C}(\mathrm{O}) \mathrm{OH}$ & $2.2 \times 10^{3} \mathrm{c}$ & $6583^{c}$ & 4.84 & $5.3 \times 10^{4}$ \\
\hline$n$-Hexanoic, $n-\mathrm{C}_{5} \mathrm{H}_{11} \mathrm{C}(\mathrm{O}) \mathrm{OH}$ & $1.4 \times 10^{3} \mathrm{c}$ & $6304^{c}$ & 4.85 & $3.0 \times 10^{4}$ \\
\hline Pyruvic, $\mathrm{CH}_{3} \mathrm{C}(\mathrm{O}) \mathrm{C}(\mathrm{O}) \mathrm{OH}$ & $3.1 \times 10^{5} \mathrm{c}$ & $5100^{c}$ & 2.39 & $7.5 \times 10^{8}$ \\
\hline Oxalic, $\mathrm{HO}(\mathrm{O}) \mathrm{CC}(\mathrm{O}) \mathrm{OH}$ & $5 \times 10^{8 f}$ & & & \\
\hline Malonic, $\mathrm{HO}(\mathrm{O}) \mathrm{CCH}_{2} \mathrm{C}(\mathrm{O}) \mathrm{OH}$ & $4 \times 10^{8 \mathrm{f}}$ & & & \\
\hline Succinic, $\mathrm{HO}(\mathrm{O}) \mathrm{C}\left(\mathrm{CH}_{2}\right)_{2} \mathrm{C}(\mathrm{O}) \mathrm{OH}$ & $3 \times 10^{8 f}$ & & & \\
\hline
\end{tabular}

a: from http://www.zirchrom.com/organic.htm; b: average from Khan et al. ${ }^{120}$ and Johnson et al. $^{121}$; c: Khan et al. ${ }^{120}$; d: Johnson et al. ${ }^{121}$; e: average of values for formic, acetic, $n$-pentanoic, and $n$-hexanoic acids; $\mathrm{f}: \mathrm{H}^{*}$, Saxena and Hildemann ${ }^{117}$. 


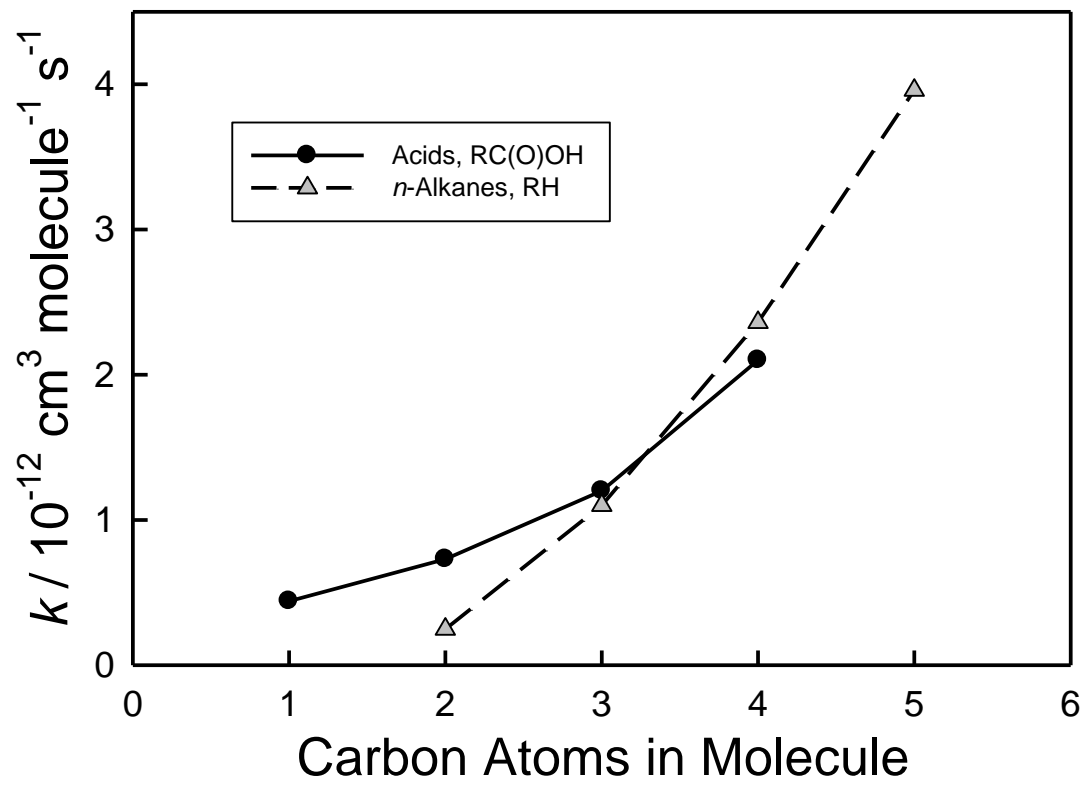

Figure 10. Rate constants for reactions of $\mathrm{OH}$ radicals with $\mathrm{HC}(\mathrm{O}) \mathrm{OH}, \mathrm{CH}_{3} \mathrm{C}(\mathrm{O}) \mathrm{OH}$,

$\mathrm{C}_{2} \mathrm{H}_{5} \mathrm{C}(\mathrm{O}) \mathrm{OH}$, and $n-\mathrm{C}_{3} \mathrm{H}_{7} \mathrm{C}(\mathrm{O}) \mathrm{OH}$ and n-alkanes at $298 \mathrm{~K}^{8}$

\subsection{Halogenated OVOCs}

Halogenated ethers, alcohols, and ketones have been developed as replacements for chlorofluorocarbons and halons (e.g., hydrofluoroethers, HFEs) in applications such as the cleaning of electronic equipment, heat transfer, lubricant deposition, and fire suppression. Halogenated ethers are used as inhalation anaesthetics (e.g., desflurane $\left[\mathrm{CHF}_{2} \mathrm{OCHFCF}_{3}\right]$, isoflurane $\left[\mathrm{CHF}_{2} \mathrm{OCHClCF}_{3}\right]$, sevoflurane $\left.\left[\left(\mathrm{CF}_{3}\right)_{2} \mathrm{CHOCH}_{2} \mathrm{~F}\right]\right)$. To avoid stratospheric ozone depletion by the well-established chlorine- and bromine-based catalytic cycles, the halogenated 
OVOCs developed as CFC and halon replacements generally do not contain chlorine or bromine.

With the exception of the anaesthetic gas isoflurane $\left(\mathrm{CHF}_{2} \mathrm{OCHClCF}_{3}\right)$, all halogenated OVOCs in commercial use to our knowledge are fluorinated organic compounds. Following their use halogenated OVOCs may be released into the atmosphere.

The atmospheric lifetime of most halogenated OVOCs is determined by their reaction with $\mathrm{OH}$ radicals. The $\mathrm{C}-\mathrm{F}$ bond is chemically inert and fluorination of organic molecules tends to deactivate the remaining $\mathrm{C}-\mathrm{H}$ bonds. Fluorinated organic compounds are less reactive towards $\mathrm{OH}$ radicals and have longer atmospheric lifetimes than their non-fluorinated counterparts. This trend is illustrated in Table 8 for mono-, di-, and tri-fluoroethanol. The atmospheric lifetime of ethanol with respect to reaction with $\mathrm{OH}$ radicals is approximately 4 days. ${ }^{8}$ The atmospheric lifetimes of $\mathrm{CH}_{2} \mathrm{FCH}_{2} \mathrm{OH}, \mathrm{CHF}_{2} \mathrm{CH}_{2} \mathrm{OH}$, and $\mathrm{CF}_{3} \mathrm{CH}_{2} \mathrm{OH}$ are approximately 20.4 days, 40 days, and 0.3 years. $^{122}$ In the extreme case of perfluorinated saturated OVOCs such as $\mathrm{CF}_{3} \mathrm{OCF}\left(\mathrm{CF}_{3}\right) \mathrm{CF}_{2} \mathrm{OCF}_{2} \mathrm{OCF}_{3}$ there is no reaction with $\mathrm{OH}$ radicals or other oxidants in the troposphere. As with their alkane counterparts, ${ }^{123}$ the atmospheric lifetimes of saturated perfluoro-OVOCs are determined by photolysis and reaction with $\mathrm{O}\left({ }^{1} \mathrm{D}\right)$ atoms. Saturated perfluorinated ethers do not absorb significantly at wavelengths above $200 \mathrm{~nm}$ and hence their atmospheric lifetimes are determined by the time taken (centuries) for transport to altitudes $>80$ $\mathrm{km}$ where UV radiation with wavelengths below $200 \mathrm{~nm}$ is available. ${ }^{124}$ In contrast, fluorinated 
ketones have a strong absorption band at approximately $300 \mathrm{~nm}$ and undergo photolysis in the troposphere and have an atmospheric lifetime of approximately 1 week. ${ }^{125-126}$ In contrast to nonfluorinated esters, uptake into the ocean and hydrolysis can be a significant atmospheric loss mechanism for fluorinated esters. ${ }^{127-128}$ The lifetime of fluorinated esters with respect to loss to the ocean is of the order of a year. The wide range of lifetimes of halogenated OVOCs is illustrated by the data for representative compounds shown in Table 8 .

Compounds containing C-F bonds have strong absorptions in the infra-red (IR) "atmospheric window" region. Absorption in this region is effective in hindering the loss of terrestrial radiation into space and contributes to the greenhouse effect. Radiative efficiency is a measure, on a per molecule basis, of the ability of a compound to contribute to the greenhouse effect and has units of $\mathrm{W} \mathrm{m} \mathrm{mpb}^{-1}$. The radiative efficiencies for selected halogenated OVOCs evaluated by Hodnebrog et al. ${ }^{122}$ are listed in Table 8 . Radiative efficiency is evaluated on a per molecule basis and is dependent on the number and type of C-F bonds in the molecule. The global warming potential of a molecule is a measure of the ability of a given mass of gas to trap heat in the atmosphere relative to that of the same mass of $\mathrm{CO}_{2}$. The global warming potential is the time-integrated radiative forcing due to a pulse emission of a gas relative to that for the same mass of $\mathrm{CO}_{2}$. The global warming potentials of selected OVOCs are given in Table 8. 
Table 8. Atmospheric lifetimes, radiative efficiencies, and global warming potentials for selected halogenated OVOCs, unless otherwise indicated data were taken from Hodnebrog et al. ${ }^{122}$ Compounds are ordered by GWP.

\begin{tabular}{|c|c|c|c|c|}
\hline Name & Formula & $\begin{array}{l}\text { Lifetime } \\
(\mathrm{yr})\end{array}$ & $\begin{array}{c}\text { Radiative } \\
\text { efficiency (W m- } \\
\left.2 \mathrm{ppb}^{-1}\right)\end{array}$ & $\begin{array}{l}\text { Global } \\
\text { Warming } \\
\text { Potential }\end{array}$ \\
\hline HFE-125 & $\mathrm{CHF}_{2} \mathrm{OCF}_{3}$ & 119.0 & 0.41 & 12,400 \\
\hline $\begin{array}{l}\text { PFPMIE, } \\
\text { perfluoropolymethylisopropylether }\end{array}$ & $\begin{array}{l}\mathrm{CF}_{3} \mathrm{OCF}\left(\mathrm{CF}_{3}\right) \mathrm{CF}_{2} \mathrm{OCF}_{2} \mathrm{O} \\
\mathrm{CF}_{3}\end{array}$ & 800 & 0.65 & 9,710 \\
\hline HFE-227ea & $\mathrm{CF}_{3} \mathrm{CHFOCF}_{3}$ & 51.6 & 0.44 & 6,450 \\
\hline HFE-236ca12 (HG-10) & $\mathrm{CHF}_{2} \mathrm{OCF}_{2} \mathrm{OCHF}_{2}$ & 25.0 & 0.65 & 5,350 \\
\hline HFE-329mcc 2 & $\mathrm{CHF}_{2} \mathrm{CF}_{2} \mathrm{OCF}_{2} \mathrm{CF}_{3}$ & 22.5 & 0.53 & 3,070 \\
\hline HFE-338pcc13 (HG-01) & $\mathrm{CHF}_{2} \mathrm{OCF}_{2} \mathrm{CF}_{2} \mathrm{OCHF}_{2}$ & 12.9 & 0.86 & 2,910 \\
\hline HFE-43-10pccc124 (HG-11) & $\mathrm{CHF}_{2} \mathrm{OCF}_{2} \mathrm{OC}_{2} \mathrm{~F}_{4} \mathrm{OCHF}_{2}$ & 13.5 & 1.02 & 2,820 \\
\hline HFE-236ea2 (desflurane) & $\mathrm{CHF}_{2} \mathrm{OCHFCF}_{3}$ & 10.8 & 0.45 & 1,790 \\
\hline HFE-236fa & $\mathrm{CF}_{3} \mathrm{CH}_{2} \mathrm{OCF}_{3}$ & 7.5 & 0.36 & 979 \\
\hline HFE-245fa1 & $\mathrm{CHF}_{2} \mathrm{CH}_{2} \mathrm{OCF}_{3}$ & 6.6 & 0.31 & 828 \\
\hline HFE-245fa2 & $\mathrm{CHF}_{2} \mathrm{OCH}_{2} \mathrm{CF}_{3}$ & 5.5 & 0.36 & 812 \\
\hline HFE-356pcf2 & $\mathrm{CHF}_{2} \mathrm{CH}_{2} \mathrm{OCF}_{2} \mathrm{CHF}_{2}$ & 5.7 & 0.37 & 719 \\
\hline HFE-245cb2 & $\mathrm{CF}_{3} \mathrm{CF}_{2} \mathrm{OCH}_{3}$ & 4.9 & 0.33 & 654 \\
\hline HFE-347mcc3 (HFE-7000) & $\mathrm{CH}_{3} \mathrm{OCF}_{2} \mathrm{CF}_{2} \mathrm{CF}_{3}$ & 5.0 & 0.35 & 530 \\
\hline HFE-143a & $\mathrm{CH}_{3} \mathrm{OCF}_{3}$ & 4.8 & 0.18 & 523 \\
\hline HCFE-235da2 (isoflurane) & $\mathrm{CHF}_{2} \mathrm{OCHClCF}_{3}$ & 3.5 & 0.42 & 491 \\
\hline HFE-449s1 (HFE-7100) & $\mathrm{CH}_{3} \mathrm{OC}_{4} \mathrm{~F}_{9} \mathrm{O}$ & 4.7 & 0.36 & 421 \\
\hline HFE-347mmz1 (sevoflurane) & $\left(\mathrm{CF}_{3}\right)_{2} \mathrm{CHOCH}_{2} \mathrm{~F}$ & 2.2 & 0.32 & 216 \\
\hline Trifluoromethyl formate & $\mathrm{HC}(\mathrm{O}) \mathrm{OCF}_{3}$ & $1.0^{\mathrm{a}}$ & 0.31 & $167^{\mathrm{a}}$ \\
\hline Perfluoroethyl formate & $\mathrm{HC}(\mathrm{O}) \mathrm{OCF}_{2} \mathrm{CF}_{3}$ & $1.0^{\mathrm{a}}$ & 0.44 & $165^{\mathrm{a}}$ \\
\hline HFE-569sf2 (HFE-7200) & $\mathrm{C}_{4} \mathrm{~F}_{9} \mathrm{OC}_{2} \mathrm{H}_{5}$ & 0.8 & 0.30 & 57 \\
\hline 2,2,2-Trifluoroethanol & $\mathrm{CF}_{3} \mathrm{CH}_{2} \mathrm{OH}$ & 0.3 & 0.10 & 20 \\
\hline
\end{tabular}




\begin{tabular}{|c|c|c|c|c|}
\hline HFE-356mmz1 & $\left(\mathrm{CF}_{3}\right)_{2} \mathrm{CHOCH}_{3}$ & 97.1 days & 0.15 & 14 \\
\hline 2,2-Difluoroethanol & $\mathrm{CHF}_{2} \mathrm{CH}_{2} \mathrm{OH}$ & 40.0 days & 0.04 & 3 \\
\hline HFE-365mcf3 & $\mathrm{CF}_{3} \mathrm{CF}_{2} \mathrm{CH}_{2} \mathrm{OCH}_{3}$ & 19.3 days & 0.05 & 1 \\
\hline HFE-263fb1 & $\mathrm{CF}_{3} \mathrm{CH}_{2} \mathrm{OCH}_{3}$ & 23.0 days & 0.04 & 1 \\
\hline 2-Fluoroethanol & $\mathrm{CH}_{2} \mathrm{FCH}_{2} \mathrm{OH}$ & 20.4 days & 0.02 & $<1$ \\
\hline $4: 2 \mathrm{FTOH}$ & $\mathrm{CF}_{3}\left(\mathrm{CF}_{2}\right)_{3} \mathrm{CH}_{2} \mathrm{CH}_{2} \mathrm{OH}$ & 20 days & 0.06 & $<1$ \\
\hline $6: 2 \mathrm{FTOH}$ & $\mathrm{CF}_{3}\left(\mathrm{CF}_{2}\right)_{5} \mathrm{CH}_{2} \mathrm{CH}_{2} \mathrm{OH}$ & 20 days & 0.07 & $<1$ \\
\hline $8: 2 \mathrm{FTOH}$ & $\mathrm{CF}_{3}\left(\mathrm{CF}_{2}\right)_{7} \mathrm{CH}_{2} \mathrm{CH}_{2} \mathrm{OH}$ & 20 days & 0.05 & $<1$ \\
\hline Perfluoro-2-methyl-3-pentanone & $\mathrm{CF}_{3} \mathrm{CF}_{2} \mathrm{C}(\mathrm{O}) \mathrm{CF}\left(\mathrm{CF}_{3}\right)_{2}$ & 7.0 days & 0.03 & 0 \\
\hline
\end{tabular}

a: calculated assuming a lifetime of 1 year, see text.

\subsection{Organosulfates/organonitrates}

Organosulfates $\left(\mathrm{OSs}, \mathrm{ROSO}_{3} \mathrm{H}\right)$ and organonitrates $\left(\mathrm{ONs}, \mathrm{RONO}_{2}\right)$ are significant components of aerosol organic matter. OSs and ONs contain sulfate or nitrate functional groups, which are hygroscopic or hydrophilic. Aerosols, containing OSs and ONs can act as cloud condensation nuclei (CCN) and hence can impact climate. OSs exist mainly in the aerosol phase. ONs exist in both gas and aerosol phases. Aerosol OSs and ONs have been reported in laboratory-generated SOA, field measurement of particulates, rainwater, fog and cloud water.

Blando et al. ${ }^{129}$ observed IR absorption features attributable to the presence of organosulfur compounds in particle samples collected in the Smoky Mountains at Look Rock, TN in 1995. It was concluded that secondary formation processes have a large influence on the concentrations, composition, and size distributions of the Smoky Mountain aerosol. OSs were identified in humic-like substances (HULIS) in atmospheric particulate matter $\left(\mathrm{PM}_{10}\right)$ in the region of Basel, Switzerland. ${ }^{130}$ HULIS were separated from inorganic salts by size exclusion chromatography 
and detected by electrospray ionization. A representative molecular ion was identified at $\mathrm{m} / \mathrm{z} 299$ and many of its fragment spectra contained a fragment $\mathrm{m} / \mathrm{z} 97$ and a neutral loss of $80 \mathrm{u}$. Timeof-flight MS and deuterium exchange experiments identified $\mathrm{m} / z$ 97 as hydrogen sulfate $\left(\mathrm{HSO}_{4}{ }^{-}\right.$ ). ${ }^{130}$ OSs, ONs, and organics containing both sulfates and nitrate groups were identified in the water-soluble organic fractions of aerosol samples collected in summer 2005 in Riverside, CA. ${ }^{131}$ Evidence that some of the sulfur occurs as a sulfate moiety was provided by ESI-MS/MS with the loss of $80 \mathrm{u}\left(-\mathrm{SO}_{3}\right.$ from $\left.\mathrm{m} / z, 293\right)$ and the presence of $\mathrm{m} / z, 97\left(\mathrm{HSO}_{4}{ }^{-}\right)$. These fragmentations are consistent with published data of $\mathrm{PM}_{10}$ material from Switzerland. ONs were identified from the fragments at $63 \mathrm{u}\left(-\mathrm{HNO}_{3}\right)$ and $62 \mathrm{u}\left(\mathrm{NO}_{3}{ }^{-}\right) \cdot{ }^{131-132}$ OSs and ONs are found in fog ${ }^{133}$ and cloud $^{134-136}$ in ambient particular aerosol from Asia ${ }^{137-138}$ to North West Europe. ${ }^{139}$

The first evidence of the formation of OSs in a laboratory study was provided in a study of the reactive uptake of glyoxal $(\mathrm{HC}(\mathrm{O}) \mathrm{C}(\mathrm{O}) \mathrm{H})$ onto particulate matter in a Teflon chamber when inorganic seed particles including $\left(\mathrm{NH}_{4}\right)_{2} \mathrm{SO}_{4},\left(\mathrm{NH}_{4}\right)_{2} \mathrm{SO}_{4} / \mathrm{H}_{2} \mathrm{SO}_{4}$ were introduced. ${ }^{140} \mathrm{~A}$ mechanism for the formation of glyoxal sulfates in particulate matter was proposed ${ }^{140}$ in which glyoxal is first hydrated and protonated, followed by reaction with sulfate species, sulfuric acid, bisulfate or sulfate. Subsequent loss or gain of a proton results in the neutral compound $\mathrm{HO}_{\mathrm{O}-\mathrm{O}}^{\mathrm{O}-\mathrm{OH}}$, and cyclization of this compound can produce the organosulfate

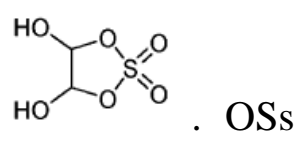
have been observed using aerosol mass spectrometry in studies of the reaction of gas phase pinonaldehyde with acidic sulfate aerosols. ${ }^{141}$ In those experiments OSs were a significant fraction of the pinonaldehyde reaction products and OSs accounted for 6-51\% of the initial $\mathrm{SO}_{4}{ }^{2-}$ mass. The existence of OSs was also confirmed in studies of the reaction system in bulk solution. The formation of OSs suggests that conventional inorganic $\mathrm{SO}_{4}{ }^{2-}$ chemical analysis may underestimate total sulfate mass in ambient aerosols. ${ }^{141}$ Direct esterification reactions between 
alcohols and sulfuric acid to form sulfate esters in aerosol particles have been explored for a number of simple alcohols and shown to be of negligible atmospheric importance. ${ }^{142}$ Sulfate esters are formed by photochemistry induced oligomerization processes involving CHOS molecules and are important constituents of the water-soluble organic fraction (WSOC) of SOA. ${ }^{143}$ High resolution mass spectrometry analysis of aqueous extracts of SOA generated from the ozonolysis of d-limonene in the presence of $\left(\mathrm{NH}_{4}\right)_{2} \mathrm{SO}_{4}$ aerosol has shown the formation of OSs. $^{144}$

The contribution of OSs to the total ambient aerosol organic mass varies greatly with location and time and is approximately $0.2-30 \%$. OSs were found to comprise less than $1 \%$ of the average organic aerosol in Whistler, British Columbia. ${ }^{145}$ A semi-quantitative analysis estimated that OSs account for less than $1 \%$ of $\mathrm{PM}_{2.5}$ mass and $3.8 \%$ of total sulfate in four sites spanning urban and remote locations in Asia. ${ }^{138}$ On average OSs have been reported to comprise about $10 \%$ of the organic mass in submicron Arctic aerosol. ${ }^{146}$ In 12 sites across the U.S., OSs accounted for approximately $5-10 \%$ of the organic mass in the ambient aerosols. ${ }^{147}$ OSs account for $6-14 \%$ of the sulfate concentration in ambient aerosol ${ }^{148}$, and may account for up to $30 \%$ of the total organic mass of ambient aerosol ${ }^{149}$ collected in a background monitoring site in Hungary. In a study of isolated organic matter analytes from fog water it was found that neutral losses of $\mathrm{SO}_{3}$ and $\mathrm{SO}_{4}$ occurred in $85 \%$ and $27 \%$ of the $\mathrm{CHOS}$ compounds and in $42 \%$ and $0 \%$ of the CHNOS compounds. ${ }^{150}$ Single particle mass spectrometry indicated that OSs are present in $80 \%$ of particles in the tropical free troposphere and that IEPOX (epoxydiol, ноsulfate ester is one of the most abundant organic compounds measured in atmospheric aerosol. ${ }^{151}$

Aerosol OSs are formed in the oxidation of biogenic precursors, such as isoprene, $\alpha-/ \beta$ pinene, $d$-/l-limonene, $\alpha$ - $/ \gamma$-terpinene, terpinolene, $\Delta^{3}$-carene, $\beta$-phellandrene, pinonaldehydes, 
and glyoxal in the presence of acid aerosols. ${ }^{149}$ Other precursor compounds for OSs include methylglyoxal, glycoaldehyde, methacrolein, methyl vinyl ketone, ${ }^{152}$ and glycolic and lactic acids. It has been recognized recently that aromatic compounds can be important OS precursors, ${ }^{153-154}$ the contribution of aromatic OS to total OSs has been measured at $63.5 \%$ in winter in Shanghai, China. ${ }^{154}$

Organic sulfate esters have been identified in laboratory investigations of the SOA formed from acidic seed particles ${ }^{140}$ and the photochemical oxidation products of isoprene, ${ }^{155-156} \alpha-/ \beta$ pinene, ${ }^{155,157}$ limonene ${ }^{158}$ and others ${ }^{142}$. Based on results from a series of controlled chamber experiments, Surratt et al. ${ }^{155}$ proposed a formation mechanism of sulfate esters via alcohol and aldehyde intermediates generated in the photooxidation of isoprene and $\alpha$-pinene. In the case of sulfate ester formation from alcohols, the proposed reactions likely involve nucleophilic substitution, where the sulfuric acid protonates the alcoholic group, making water the leaving group. ${ }^{155}$ Iinuma et al. ${ }^{157}$ investigated the formation of OSs from the gas-phase ozonolysis of $\beta$ pinene in the presence of neutral or acidic sulfate particles by HPLC/ESI-TOFMS and found that OSs were formed in SOA in the presence of acidic sulfate seed particles. The proposed reaction pathways for the formation of OSs compounds in the OH-initiated oxidation of isoprene and $\alpha$ pinene, and in the ozonolysis of $\beta$-pinene in the presence of sulfuric acid are shown in Scheme 5. 


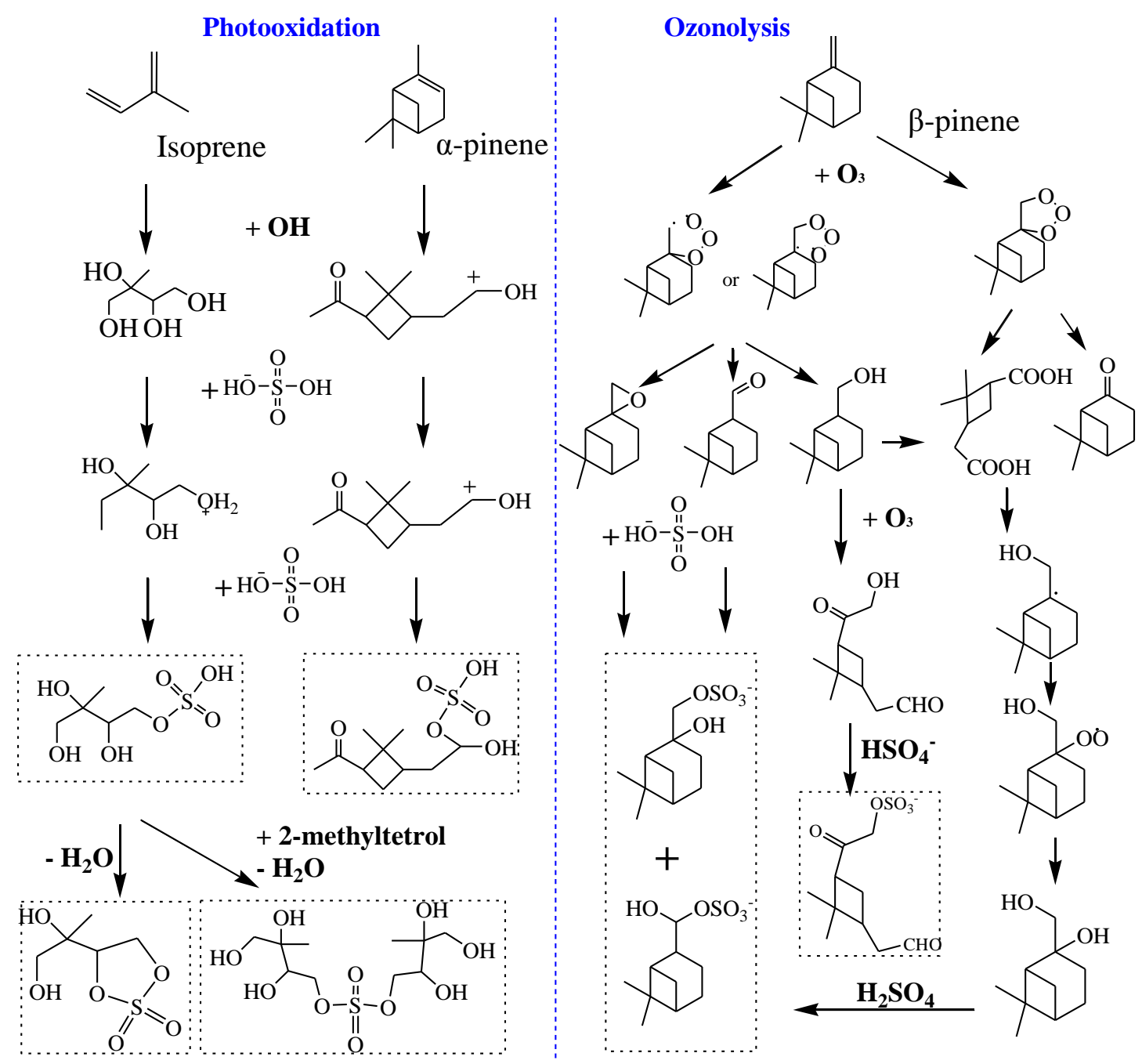

Scheme 5. Proposed reaction pathways for the formation of sulfate esters in the photooxidation of isoprene and $\alpha$-pinene ${ }^{149}$ and ozonolysis of $\beta$-pinene ${ }^{157}$. OSs are indicated by the dotted boxes. Adapted from refs. ${ }^{149,155,157}$

The uptake of reactive species on acidic sulfate aerosols leads to the formation of OSs. ${ }^{141-}$ 142,152,159-161 The reactive species include glyoxal, ${ }^{140}$ pinonaldehyde, ${ }^{141}$ methylglyoxal, ${ }^{161}$ monoterpene oxides ( $\alpha$-pinene oxide and $\beta$-pinene oxide) and acid catalyzed isomerization 
compounds of $\alpha$-pinene oxide (campholenic aldehyde and carveol), ${ }^{152,159}$ and several carbonyl compounds (formaldehyde, octanal, trans,trans-2,4-hexadienal, 2,3-butanedione, 2,4pentanedione, glutaraldehyde, and hydroxyacetone). ${ }^{160}$

Nguyen et al. ${ }^{162}$ investigated the reactive uptake of isoprene cis- and trans-IEPOX onto non-acidified inorganic seeds and demonstrated that the conversion of IEPOX to organic aerosol depends on the coupled relationship between the inorganic composition and liquid water content of the particle $\left(P_{\mathrm{LWC}}\right)$. The inorganic composition governs the catalyst and nucleophile characteristics, and $P_{\text {LWC }}$ provides a reaction medium for the partitioning of IEPOX and controls the activities of all the aqueous components.

Surratt et al. ${ }^{163}$ found that the NOx concentration has a significant effect on the formation of isoprene-derived OSs via two key reactive intermediates IEPOX and methacryloylperoxynitrate (MPAN) which are formed during isoprene oxidation under low- and high-NOx conditions, respectively. Isoprene low-NOx SOA is enhanced in the presence of acidified sulfate seed aerosol (mass yield 28.6\%) over that in the presence of neutral aerosol (mass yield 1.3\%). Hydroxy sulfate ester and its dimer are formed in the aerosol phase under low-NOx conditions due to increased aerosol acidity. Under high-NOx conditions, isoprene SOA formation occurs through oxidation of its reactive intermediate, MPAN. The similarity of the composition of SOA formed from the photooxidation of MPAN to that formed from isoprene 
and methacrolein suggests the role of MPAN in the formation of isoprene high-NOx SOA. ${ }^{163}$ After loss of water in the decomposition of the C4-hydroxynitrate-PAN, the oligoester of 2methylglyceric (2-MG) is formed in the aerosol phase under high-NOx conditions. Worton et al. ${ }^{164}$ concluded the strong temperature dependence of MPAN formation helps to explain observations of similar concentrations of IEPOX-derived OS and methacrylic acid epoxide (MAE)-derived OSs under cooler conditions (lower isoprene concentrations) and much higher IEPOX-OSs relative to MAE-OSs at higher temperatures (higher isoprene concentrations). The formation of the IEPOX- ${ }^{163,165}$ and MAE-derived OSs ${ }^{163,166-167}$ can be from the $\mathrm{HO}_{2}$ and NO/NO 2 pathways, respectively. The organosulfates formed from IEPOX and MAE only form through ring-opening epoxide chemistry, due to kinetic limitations of the sulfate alcohol esterification reaction, ${ }^{142}$ and have been speculated to be among the products responsible for the enhancement of SOA under acidic conditions. ${ }^{156,163}$

Scheme 6 shows the formation of OSs and ONs from the addition of weak nucleophiles in the aqueous $\mathrm{NH}_{4}{ }^{+}$and $\mathrm{H}^{+}$-catalyzed ring opening of IEPOX to form low-volatility OSs, and the enhancement of SOA formation from isoprene under low and high-NOx conditions. 


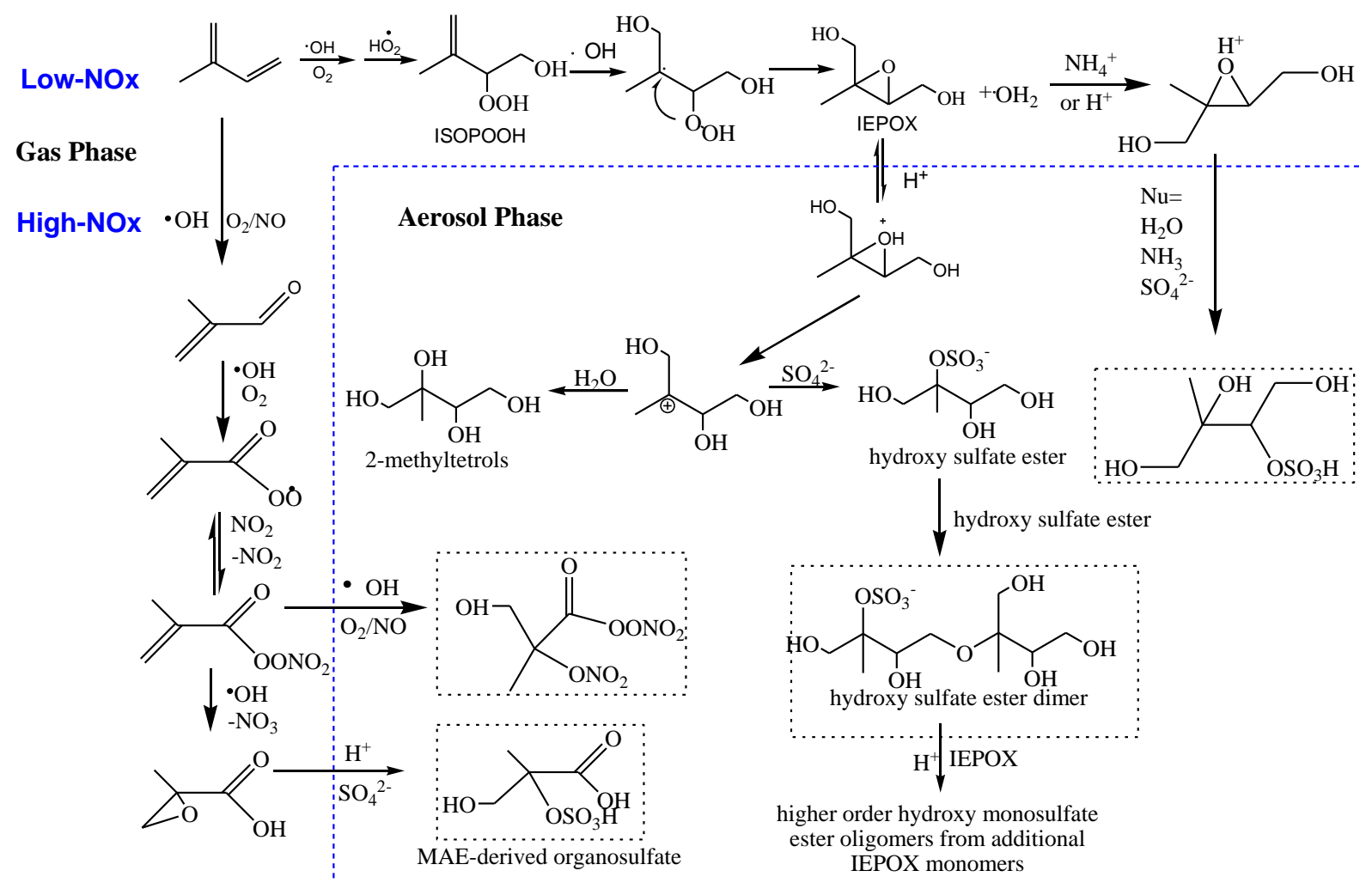

Scheme 6. Mechanism for OSs and ONs formation during isoprene oxidation. OSs and ONs are indicated by dotted boxes. Adapted from ref. ${ }^{142,157,162-164}$

Nitrooxy-organosulfates were observed as prominent products in the $\mathrm{OH} / \mathrm{NO}_{3}$-initiated photooxidation of monoterpenes in the presence of acidified sulfate aerosol by Surratt et al. ${ }^{149}$ ONs were shown to be an important component of organic aerosol by O'Brien et al. ${ }^{168}$ in the 1970s and are still the subject of active research interest, ${ }^{169-172}$ ONs typically comprise $10-20 \%$ of the carbonaceous aerosol mass in urban locations. ${ }^{173-174}$ In wintertime measurements in coastal southern California in 2009, ON groups accounted for up to $10 \%$ of organic mass in submicron particles produced from urban combustion emissions. ${ }^{175}$ Very recently, in $\mathrm{PM}_{10}$ samples 
collected at a rural background site in Hamme, Belgium, $\alpha$-pinene-related nitrooxyorganosulfates were detected during the winter. ${ }^{176}$ In marine rainwater samples collected in on the island of Bermuda, five compound classes ${ }^{177}$ were identified that contained $\mathrm{CHON}^{+}$, $\mathrm{CHONS}^{+}, \mathrm{CHONP}^{+}, \mathrm{CHONSP}^{+}, \mathrm{CHN}^{+}$. Bleier et al. ${ }^{178}$ investigated the kinetics and thermodynamics of atmospherically relevant aqueous phase reactions of $\alpha$-pinene oxides. Their results indicated that $\alpha$-pinene oxide will react very quickly with aqueous atmospheric particles, even under low acidity conditions. Depending on the acid concentration of the aqueous solutions, a number of new products such as trans-sobrerol sulfate, trans-sobrerol nitrate, pinane-2-sulfato1-ol and pinane-2-nitrato-ol are observed from the reaction of $\alpha$-pinene oxide. No long-lived OSs or ONs species are observed.

Other important sulfur-/nitrogen-containing organics include alkyl-sulfonic acids such as methanesulfonic acid $\left(\mathrm{CH}_{3} \mathrm{~S}(\mathrm{O})_{2} \mathrm{OH}, \mathrm{MSA}\right)$, and peroxyacylnitrates $\left(\mathrm{RC}(\mathrm{O}) \mathrm{O}_{2} \mathrm{NO}_{2}\right),{ }^{179}$ such as peroxyacetyl nitrate (PAN) and its analogs (PANs). ${ }^{180}$ MSA and many sulfur-containing organics such as dimethyl sulfoxide $\left(\mathrm{CH}_{3} \mathrm{SOCH}_{3}, \mathrm{DMSO}\right)$ and dimethyl sulfone $\left(\mathrm{CH}_{3} \mathrm{SO}_{2} \mathrm{CH}_{3}, \mathrm{DMSO}_{2}\right)$ are oxidation products dimethyl sulfide (DMS, $\mathrm{CH}_{3} \mathrm{SCH}_{3}$ ). DMS is produced from the oceanic degradation of dimethylsulphoniopropionate (DMSP) released from some phytoplankton species. ${ }^{181-182}$ On a global scale biogenic emissions of DMS are important with contributions to the sulfur budget of $15-20 \%$ and $50-60 \%$ in the Northern and Southern Hemispheres, 
respectively. ${ }^{183-186}$ Kloster et al. ${ }^{187}$ estimated an annual mean DMS emission of $28 \mathrm{Tg}(\mathrm{S}) \mathrm{yr}^{-1}$ and a DMS burden in the atmosphere of $0.077 \mathrm{Tg}(\mathrm{S})$ from marine sources. ${ }^{188}$

MSA, DMSO and $\mathrm{DMSO}_{2}$ are the main DMS gaseous oxidation products of sulfurcontaining organics. Barnes et al. et al. ${ }^{184}$ outlined the $\mathrm{OH}$ and $\mathrm{NO}_{3}$-initiated DMS oxidation mechanism. The formation of sulfur-containing organics from DMS reaction with the $\mathrm{OH}$ radical can be summarized as follow:

$$
\begin{aligned}
& \mathrm{OH}+\mathrm{CH}_{3} \mathrm{SCH}_{3} \rightarrow \mathrm{CH}_{3} \mathrm{SCH}_{2}+\mathrm{H}_{2} \mathrm{O} \\
& \mathrm{OH}+\mathrm{CH}_{3} \mathrm{SCH}_{3}(+\mathrm{M}) \leftrightarrow \mathrm{CH}_{3} \mathrm{~S}(\mathrm{OH}) \mathrm{CH}_{3}(+\mathrm{M}) \\
& \mathrm{OH}+\mathrm{CH}_{3} \mathrm{SCH}_{3} \rightarrow \mathrm{CH}_{3}+\mathrm{CH}_{3} \mathrm{SOH} \\
& \mathrm{OH}+\mathrm{CH}_{3} \mathrm{SCH}_{3} \rightarrow \mathrm{CH}_{3} \mathrm{~S}+\mathrm{CH}_{3} \mathrm{OH}
\end{aligned}
$$

$\mathrm{M}$ is a third body, typically $\mathrm{N}_{2}$ or $\mathrm{O}_{2}$.

$$
\begin{aligned}
& \mathrm{CH}_{3} \mathrm{~S}(\mathrm{OH}) \mathrm{CH}_{3}+\mathrm{O}_{2}+\mathrm{M} \rightarrow \mathrm{HO}_{2}+\mathrm{CH}_{3} \mathrm{~S}(\mathrm{O}) \mathrm{CH}_{3}(\mathrm{DMSO})+\mathrm{M} \\
& \mathrm{CH}_{3} \mathrm{~S}(\mathrm{OH}) \mathrm{CH}_{3}+\mathrm{O}_{2} \rightarrow \mathrm{CH}_{3} \mathrm{OO}+\mathrm{CH}_{3} \mathrm{SOH} \\
& \mathrm{CH}_{3} \mathrm{~S}(\mathrm{OH}) \mathrm{CH}_{3}+\mathrm{O}_{2} \rightarrow \mathrm{OH}+\mathrm{CH}_{3} \mathrm{~S}(\mathrm{O})_{2} \mathrm{CH}_{3}\left(\mathrm{DMSO}_{2}\right) \\
& \mathrm{CH}_{3} \mathrm{~S}(\mathrm{OH}) \mathrm{CH}_{3}+\mathrm{O}_{2} \rightarrow \mathrm{CH}_{3}+\mathrm{CH}_{3} \mathrm{~S}(\mathrm{O})_{2}(\mathrm{OH})(\mathrm{MSA})
\end{aligned}
$$

The DMS oxidation products methane sulfonic acid and gas phase sulfuric acid lead to the formation aerosols and can impact climate. It has been postulated that emission of DMS from 
the oceans acts as a negative feedback mechanism where biota can regulate the climate. ${ }^{189}$ The idea, which has become known as the CLAW hypothesis (acronym of author names), is that increased ocean temperature causes increased phytoplankton activity leading to increased DMS emissions, increased cloud condensation nuclei, increased cloud albedo and reflection of solar radiation, and hence a negative feedback regulating global temperature. Interestingly, one of the authors of the CLAW hypothesis subsequently proposed there may be an anti-CLAW hypothesis positive feedback on climate. Increased temperatures could lead to increased stratification of the oceans, lower nutrient availability, lower phytoplankton activity, lower DMS emissions, lower cloud albedo and a positive feedback on global temperature. ${ }^{190}$ While the sign and magnitude of the biological feedback mechanism regulating climate through DMS emissions is currently unclear it is clear that the gas-phase oxidation of DMS may have a significant influence on the Earth's radiation budget.

PAN $\left(\mathrm{CH}_{3}(\mathrm{O}) \mathrm{O}_{2} \mathrm{NO}_{2}\right)$ and peroxyacyl nitrates in general $\left(\mathrm{R}(\mathrm{O}) \mathrm{O}_{2} \mathrm{NO}_{2}\right)$ are well known components of photochemical smog and are formed by reactions involving VOCs and $\mathrm{NO}_{\mathrm{x}}$. PAN was first observed in photochemical smog in California in the 1950 s $^{191-192}$ and is now recognized to be a ubiquitous trace gas in the troposphere ${ }^{33,193}$. PAN is formed in the association reaction of peroxyacetyl radicals $\left(\mathrm{CH}_{3} \mathrm{C}(\mathrm{O}) \mathrm{O}_{2}\right)$ and $\mathrm{NO}_{2}$.

$$
\mathrm{CH}_{3} \mathrm{C}(\mathrm{O}) \mathrm{O}_{2}+\mathrm{NO}_{2}+\mathrm{M} \rightarrow \mathrm{CH}_{3} \mathrm{C}(\mathrm{O}) \mathrm{O}_{2} \mathrm{NO}_{2}(\mathrm{PAN})+\mathrm{M}
$$




$$
\begin{aligned}
& \mathrm{CH}_{3} \mathrm{C}(\mathrm{O}) \mathrm{O}_{2} \mathrm{NO}_{2}(\mathrm{PAN})+\mathrm{M} \rightarrow \quad \mathrm{CH}_{3} \mathrm{C}(\mathrm{O}) \mathrm{O}_{2}+\mathrm{NO}_{2}+\mathrm{M} \\
& \mathrm{CH}_{3} \mathrm{C}(\mathrm{O}) \mathrm{O}_{2}+\mathrm{NO} \rightarrow \mathrm{CH}_{3}+\mathrm{CO}_{2}+\mathrm{NO}_{2}
\end{aligned}
$$

Peroxyacetyl radicals are formed in the oxidation of many VOCs. Using a global 3-D chemical transport model (GEOS-Chem) Fischer et al. ${ }^{194}$ found that many NMVOC emissions are responsible for PAN formation globally including isoprene (37\%), alkanes (14\%), and terpenes (9\%). PAN formation in the $\mathrm{OH}$-initiated atmospheric oxidation of isoprene and $\alpha$ pinene $^{192,195-198}$ is shown in scheme 7.

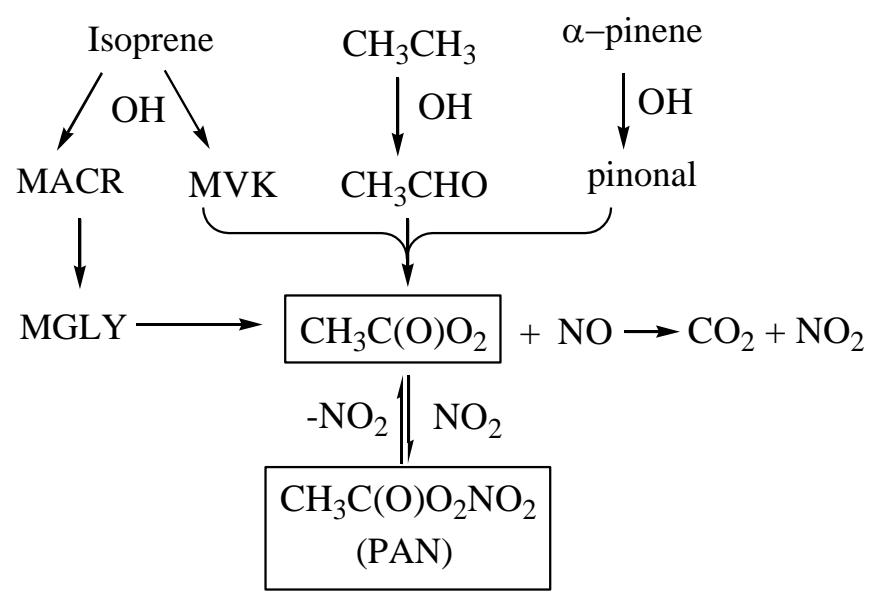

Scheme 7. Simplified reaction scheme illustrating the production of PAN during the OHinitiated oxidation of isoprene, propane and $\alpha$-pinene adapted from ref. ${ }^{195,198}$

In addition to PAN, other peroxyacyl nitrates detected in the atmosphere include peroxypropionyl nitrate ( $\mathrm{PPN}, \mathrm{CH}_{3} \mathrm{CH}_{2} \mathrm{C}(\mathrm{O}) \mathrm{O}_{2} \mathrm{NO}_{2}$ ), peroxy-n-butyl nitrate (PnBN, $\left.\mathrm{CH}_{3} \mathrm{CH}_{2} \mathrm{CH}_{2} \mathrm{C}(\mathrm{O}) \mathrm{O}_{2} \mathrm{NO}_{2}\right)$, peroxybenzoyl nitrate $\left(\mathrm{PBzN}, \quad \mathrm{CH}_{3} \mathrm{CH}_{2} \mathrm{C}(\mathrm{O}) \mathrm{O}_{2} \mathrm{NO}_{2}\right)$, and 
peroxymethacryoyl nitrate (MPAN, $\mathrm{CH}_{2}=\mathrm{C}\left(\mathrm{CH}_{3}\right)(\mathrm{O}) \mathrm{O}_{2} \mathrm{NO}_{2}$ ). PAN is the most abundant peroxyacyl nitrate and its concentration ranges from a few ppt in marine background air to more than $10 \mathrm{ppb}$ in urban air masses. PPN is the second most abundant peroxyacyl nitrate, the PPN to PAN ratio is typically in the range of $0.1-0.3$, the other peroxyacyl nitrates are typically present at lower concentrations. ${ }^{7,199-207}$ PAN reacts slowly with $\mathrm{OH}$ radicals and has a lifetime greater than a year with respect to reaction with $\mathrm{OH}$. PAN is thermally unstable and decomposes to reform the peroxyacetyl radical, $\mathrm{CH}_{3} \mathrm{C}(\mathrm{O}) \mathrm{O}_{2}$, and $\mathrm{NO}_{2} \cdot{ }^{37,202}$ PAN undergoes photolysis at a moderate rate. The lifetime of PAN with respect to photolysis is approximately 1.7 months ${ }^{8}$. As shown in Figure 11, at low altitudes the lifetime of PAN is determined by thermal decomposition and is a few hours to a few days. Thermal decomposition is the most important loss mechanism of PAN at low altitudes but becomes rapidly less important with increasing altitude and decreasing temperature. At altitudes above $4-5 \mathrm{~km}$ the lifetime of PAN is determined by photolysis and is sufficiently long for long range transport of PAN to remote areas. Mixing back to lower altitudes followed by thermal decomposition provides an important mechanism for long-range transport of $\mathrm{NOx}$ thereby affecting the production of tropospheric $\mathrm{O}_{3}$ in remote areas. ${ }^{201-203,208}$ 


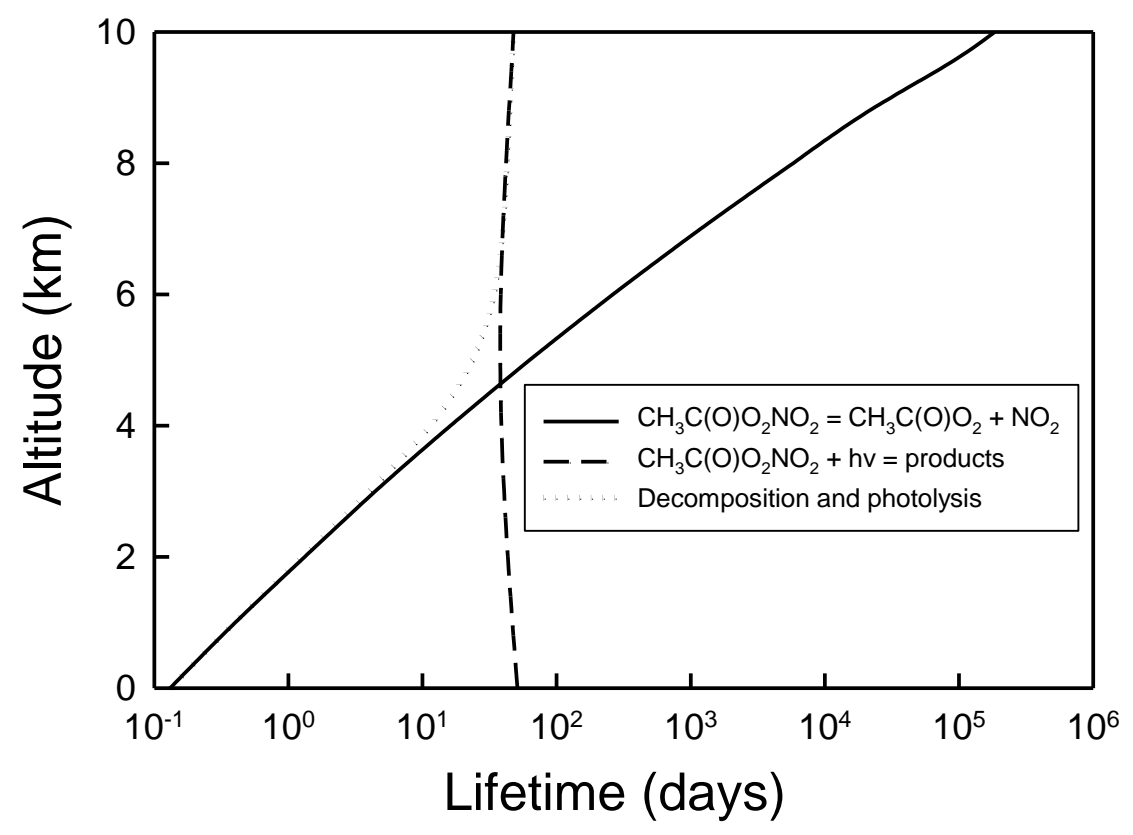

Figure 11. Altitude dependence of $\mathrm{PAN}\left(\mathrm{CH}_{3} \mathrm{C}(\mathrm{O}) \mathrm{O}_{2} \mathrm{NO}_{2}\right)$ lifetime with respect to thermal decomposition (solid line), photolysis (dashed line), and both decomposition and photolysis (dotted line)

for the U.S. Standard Atmosphere using kinetic data from Atkinson et al. ${ }^{37}$ and photolysis data from Calvert et al. ${ }^{8}$

Field study observations in Bakersfield, California by Rollins et al. ${ }^{209}$ indicate that the nighttime formation of particulate organic nitrates increases with $\mathrm{NO}_{\mathrm{x}}$, and is suppressed by high concentrations of organic molecules that react rapidly with nitrate radical $\left(\mathrm{NO}_{3}\right)$. The observations indicate that particulate organic nitrates are secondary products formed in reactions of $\mathrm{NO}_{3}$ radicals with the primary products of the $\mathrm{NO}_{3}$ radical-initiated of reactive biogenic 
organics. Organic nitrates represented about a third of the observed nighttime increase in organic aerosol, suggesting the importance of nighttime secondary organic aerosol from $\mathrm{NO}_{3}$ radicals, produced as a result of anthropogenic $\mathrm{NO}_{\mathrm{x}}$ emissions, reacting with biogenic organic compounds. Rollins et al. ${ }^{209}$ used a simple box model ${ }^{210}$ to simulate SOA formation in the $\mathrm{NO}_{3}$ radical initiated oxidation of limonene. The two reaction sites in limonene react at different rates with $\mathrm{NO}_{3}$, leading to one group of compounds with endocyclic double bonds, and another group with exocyclic double bonds. First generation products react with $\mathrm{NO}_{3}$ at rates depending on the location of the remaining double bond. The simple model of limonene oxidation indicated secondary organic aerosol formation in nighttime $\mathrm{NO}_{3}$ chemistry is a significant $\mathrm{PM}$ source in Bakersfield. $^{209}$

\section{Ozone formation from the atmospheric oxidation of OVOCs}

The atmospheric oxidation of VOCs is extremely complex and there is no simple relationship between VOC degradation and tropospheric ozone formation. Different VOCs make different contributions to ozone formation reflecting differences in VOC reactivity and chemical structure. Some organic compounds react very slowly, give relatively unreactive products, and make little contribution to ozone formation. Other compounds react rapidly, give reactive products, and make large contributions to ozone formation. Recognition of the large range of abilities for 
different VOCs to contribute to ozone formation has led to development of tools to quantify their ability to produce ground level ozone. Several different concepts for VOC ranking have been suggested and most of them include the use of atmospheric models. Atmospheric photochemical models describe the chemical and meteorological features of the atmosphere and are used to study atmospheric processes. Two scales are in common use to rank the ability of VOCs to contribute to ozone formation. Most focus to date has been placed on understanding local and regional ozone production. The scales in common use describe the ability of VOCs to contribute to local and regional ozone. It should be noted that longer lived VOCs can still contribute to ozone formation but on a larger spatial scale. To capture the effects on local and regional scales Maximum Incremental Reactivities (MIR) values are typically used in the US. ${ }^{211-212}$ Photochemical Ozone Creation Potentials (POCP) values are typically used in Europe. ${ }^{5,213-216}$

The MIR scale was developed to rank the ozone formation from different organic compounds when released in urban areas. ${ }^{212,217}$ This reactivity scale is based on calculations of the absolute ozone impact, expressed as the number of grams of ozone formed per gram of VOC, when the VOC is added to the emissions in the model. MIRs have units of $\mathrm{g} \mathrm{O}_{3} / \mathrm{g}$ VOC. MIRs can be computed for different chemical and atmospheric conditions. MIRs are based on model calculations of the effects of additions of VOCs on ozone formation in one-day box model 
scenarios representing conditions where ambient ozone is most sensitive to changes in VOC emissions. ${ }^{217}$ These calculations require a model or models for airshed conditions, a method for quantifying ozone impacts, and a chemical mechanism to calculate the effects of VOC reactions on ozone formation in the atmosphere. MIR values are calculated using the SAPRC (Statewide Air Pollution Research Center) mechanism which has been updated over the years. The MIR method has been tested under various emission conditions ${ }^{218}$ for a large number of compounds.

The POCP concept covers a longer time scale than MIR. POCP values are determined from the calculated formation of ozone in the boundary layer over a period of up to five days using a photochemical trajectory model. The POCP measures total additional ozone formed during a multi-day model by adding a given amount of volatile organic compound relative that of adding the same mass of ethane..$^{5-6,215}$ The POCP for a given VOCx is given by:

$\mathrm{POCP}_{\mathrm{x}}=\left(\right.$ ozone increment with $\mathrm{x}_{\mathrm{th}}$ VOC/ozone increment with ethene $) \times 100$

The POCP for ethene is defined as 100. Ethene is used as a reference for the POCP scale because its chemical degradation scheme is well defined and because it is one of the most important ozone forming VOCs in northwest Europe. ${ }^{215}$ The photochemical model used to derive POCP 
incorporates the near explicit chemical mechanism MCM (Master Chemical Mechanism) which describes the detailed atmospheric degradation of a large number of VOCs and their contribution to the formation of ozone under boundary layer conditions. ${ }^{219-221}$ Initially, to develop regional ozone strategies in Europe, this concept has been employed to describe regional scale ozone in a single air parcel travelling across northwest Europe for idealised conditions. ${ }^{5,215}$ It has been adapted to other situations such as Scandinavia ${ }^{213,222}$ and South East Asia ${ }^{223-224}$.

Jenkin $^{6}$ developed a simplified estimation procedure which uses fundamental molecular properties of the VOCs (molecular weight, $M$; number of $\mathrm{C}-\mathrm{C}$ and $\mathrm{O}-\mathrm{H}$ bonds, $n_{B}$; and the number of carbon atoms in the molecule, $n_{C}$ ) and the rate constant for reaction with $\mathrm{OH}$ radicals, $k_{O H}$, at $298 \mathrm{~K}$ in 760 Torr of air to estimate POCPs using the expression:

$$
\varepsilon^{\mathrm{POCP}}=\alpha_{1} \times \gamma_{\mathrm{S}} \times{\gamma_{\mathrm{R}}}^{\beta}\left(1-\alpha_{2} \times n_{C}\right)
$$

where $\varepsilon^{\mathrm{POCP}}$ is the estimated POCP; $\alpha_{1}, \alpha_{1}$ and $\beta$ are constants; $\gamma_{\mathrm{S}}$ is the structure based ozone formation index, $\gamma_{\mathrm{R}}$ is the reactivity based ozone formation index, and $n_{C}$ is the number of carbon atoms in the compound. The structure and reactivity based ozone formation indices are defined as:

$$
\gamma_{\mathrm{S}}=\left(\mathrm{n}_{\mathrm{B}} / M\right) \times(28 / 6)
$$




$$
\gamma_{\mathrm{R}}=\left(\mathrm{k}_{\mathrm{OH}} / \mathrm{n}_{\mathrm{B}}\right) \times\left(6 / k_{\mathrm{OH}}{ }^{\text {ethene }}\right)
$$

Where $k_{\mathrm{OH}}{ }^{\text {ethene }}$ is the rate constant for the reaction of $\mathrm{OH}$ radicals with ethene at $298 \mathrm{~K}$ and 760 Torr of air $\left(k_{\mathrm{OH}}{ }^{\text {ethene }}=7.8 \times 10^{-12} \mathrm{~cm}^{3}\right.$ molecule $\mathrm{s}^{-1} \mathrm{~s}^{-1}$ 225 $)$ Jenkin showed that this approach can be used to estimate POCPs for a large variety of VOCs but that it overestimates ozone formation from VOCs whose atmospheric oxidation produces significant yields of unreactive products, in particular acetone, formates and alkyl nitrates. ${ }^{5-6}$ Acetone is relatively unreactive $\left(k_{\mathrm{OH}}=1.8 \times 10^{-}\right.$ ${ }^{13} \mathrm{~cm}^{3}$ molecule $\mathrm{s}^{-1}$ at $298 \mathrm{~K}$ and 760 Torr ${ }^{225}$ ) and its formation significantly inhibits the ability of the precursor VOC to generate ozone on the timescale of the trajectory calculation. The formation of organic nitrates inhibits ozone formation because they act as comparatively unreactive reservoirs for $\mathrm{NO}_{\mathrm{x}}$ and free radicals. ${ }^{221}$ Good agreement was obtained between results from this simple estimation technique and those calculated using photochemical models for a large number of VOCs but discrepancies have been observed for some oxygenated VOCs as discussed by Jenkin. ${ }^{6}$

Derwent et al. ${ }^{226}$ calculated POCP for 116 organic compounds representing different classes of organic compounds (alkanes, alkenes, aldehydes, ketones, aromatics, oxygenates, and halocarbons) using the Master Chemical Mechanism (MCMv3.1) and compared with those 
calculated with the SAPRC-07 chemical mechanism (used in MIR calculations). The study involved first-day ozone formation and then was largely representative of the chemistry of the emitted organic compounds and their first generation products. There is general agreement between POCPs using the two different mechanisms for the majority of the species. Table 9, taken from Derwent et al., ${ }^{226}$ contains the calculated POCPs for a series of oxygenated VOCs using the MCMv3.1 and SAPRC-07 mechanisms for selected test scenarios representing highly idealized ambient environmental conditions. The atmospheric oxidation of benzaldehyde leads to the formation of benzylperoxynitrate, $\mathrm{C}_{6} \mathrm{H}_{5} \mathrm{C}(\mathrm{O}) \mathrm{OONO}_{2}$, and nitrophenol which scavenge NOx resulting in a negative photochemical formation potential for benzaldehyde. Methylbenzaldehydes have similar oxidation mechanisms to benzaldehyde and also have negative POCPs. The scatterplot in Figure 12 shows that only a limited number of OVOCs exhibited inconsistent POCPs calculated using the MCMv3.1 and SAPRC-07 chemical mechanisms. Both sets of POCPs increase broadly with increasing $k_{\mathrm{OH}}$ reactivity and the general pattern of reactivity within the oxygenate classes was similar using MCMv3.1 and SAPRC-07. The POCPs determined using both chemical mechanisms follow each other closely. This indicates that the representations of the mechanistic reactivities of the oxygenated are consistent. Derwent et al. ${ }^{226}$ have concluded that MCMv3.1 and SAPRC-07 are able to characterize the reactivities of most of the oxygenated VOCs in a consistent, quantitative manner. The 
discrepancies for some species reflect differences in the kinetic parameters and chemical mechanisms used in MCMv3.1 and SAPRC-07 which are probably attributable to the lack of complete experimental data for the atmospheric degradation processes of these species. The list of these compounds includes glyoxal, methacrolein, i-propanol, 3-methyl-1-butanol, cyclohexanol and diacetone alcohol. Derwent et al. ${ }^{226}$ attributed the observed discrepancies to the fact that the atmospheric degradation mechanisms for these species are not adequately described by the available experimental data. 
Table 9: $\mathrm{OH}$ reaction rate constants with oxygenated VOCs and POCPs estimated using different chemical mechanisms.

\begin{tabular}{|c|c|c|c|c|c|c|}
\hline \multirow[t]{2}{*}{ Compound } & \multirow[t]{2}{*}{ Formula } & \multirow[t]{2}{*}{$\mathrm{k}_{\mathrm{OH}}\left(\times 10^{-12}\right)^{\mathrm{a}}$} & \multicolumn{2}{|c|}{ SAPRC- $07^{b}$} & \multicolumn{2}{|c|}{ MCMv3.1 } \\
\hline & & & POCP & s.d. & POCP & s.d. ${ }^{\mathrm{c}}$ \\
\hline \multicolumn{7}{|l|}{ Alcohols } \\
\hline Methanol & $\mathrm{CH}_{3} \mathrm{OH}$ & 0.9 & 7 & 0 & 8 & 1 \\
\hline Ethanol & $\mathrm{C}_{2} \mathrm{H}_{5} \mathrm{OH}$ & 3.2 & 14 & 2 & 17 & 5 \\
\hline Propanol & $\mathrm{C}_{3} \mathrm{H}_{7} \mathrm{OH}$ & 5.7 & 24 & 4 & 30 & 6 \\
\hline$i$-Propanol & $\mathrm{CH}_{3} \mathrm{CH}(\mathrm{OH}) \mathrm{CH}_{3}$ & 5.1 & 6 & 1 & 13 & 2 \\
\hline$n$-Butanol & $\mathrm{C}_{4} \mathrm{H}_{9} \mathrm{OH}$ & 8.2 & 28 & 4 & 35 & 8 \\
\hline$i$-Butanol & $\left(\mathrm{CH}_{3}\right)_{2} \mathrm{CHCH}_{2} \mathrm{OH}$ & 9.6 & 25 & 3 & 34 & 2 \\
\hline sec-Butanol & $\mathrm{CH}_{3} \mathrm{CH}_{2} \mathrm{CH}(\mathrm{OH}) \mathrm{CH}_{3}$ & 8.3 & 13 & 2 & 26 & 5 \\
\hline 3-Methyl-1-butanol & $\left(\mathrm{CH}_{3}\right)_{2} \mathrm{CHCH}_{2} \mathrm{CH}_{2} \mathrm{OH}$ & 14 & 32 & 3 & 47 & 3 \\
\hline Cyclohexanol & $\mathrm{C}_{6} \mathrm{H}_{11} \mathrm{OH}$ & 17 & 19 & 4 & 45 & 10 \\
\hline \multicolumn{7}{|l|}{ Glycols } \\
\hline Ethylene glycol & $\mathrm{HOCH}_{2} \mathrm{CH}_{2} \mathrm{OH}$ & 14 & 31 & 3 & 25 & 5 \\
\hline Propylene glycol & $\mathrm{CH}_{3} \mathrm{CH}(\mathrm{OH}) \mathrm{CH}_{2} \mathrm{OH}$ & 21 & 26 & 2 & 29 & 7 \\
\hline \multicolumn{7}{|l|}{ Ethers } \\
\hline Dimethylether & $\mathrm{CH}_{3} \mathrm{OCH}_{3}$ & 0.27 & 8 & 1 & 18 & 5 \\
\hline Diethylether & $\mathrm{C}_{2} \mathrm{H}_{5} \mathrm{OC}_{2} \mathrm{H}_{5}$ & 12.2 & 40 & 2 & 53 & 9 \\
\hline Di-i-propylether & $\left(\mathrm{CH}_{3}\right)_{2} \mathrm{CHOCH}\left(\mathrm{CH}_{3}\right)_{2}$ & 10.0 & 39 & 2 & 41 & 8 \\
\hline \multicolumn{7}{|l|}{ Alkoxyethers } \\
\hline 2-Methoxyethanol & $\mathrm{CH}_{3} \mathrm{OCH}_{2} \mathrm{CH}_{2} \mathrm{OH}$ & 13 & 31 & 1 & 34 & 3 \\
\hline 1-Methoxy-2-propanol & $\mathrm{CH}_{3} \mathrm{OCH}_{2} \mathrm{CH}(\mathrm{OH}) \mathrm{CH}_{3}$ & 20 & 25 & 3 & 32 & 6 \\
\hline 2-Ethoxyethanol & $\mathrm{CH}_{3} \mathrm{CH}_{2} \mathrm{OCH}_{2} \mathrm{CH}_{2} \mathrm{OH}$ & 19 & 39 & 2 & 42 & 5 \\
\hline 2-Butoxyethanol & $\mathrm{C}_{4} \mathrm{H}_{9} \mathrm{OCH}_{2} \mathrm{CH}_{2} \mathrm{OH}$ & 30 & 30 & 2 & 38 & 7 \\
\hline
\end{tabular}




\begin{tabular}{|c|c|c|c|c|c|c|}
\hline \multicolumn{7}{|l|}{ Esters } \\
\hline Methyl formate & $\mathrm{HC}(\mathrm{O}) \mathrm{OCH}_{3}$ & 0.179 & 0.5 & 0.1 & 1.0 & 0.0 \\
\hline Methyl acetate & $\mathrm{CH}_{3} \mathrm{C}(\mathrm{O}) \mathrm{OCH}_{3}$ & 0.346 & 0.7 & 0.1 & 3.0 & 1.0 \\
\hline Ethyl acetate & $\mathrm{CH}_{3} \mathrm{C}(\mathrm{O}) \mathrm{OC}_{2} \mathrm{H}_{5}$ & 1.67 & 6 & 1 & 11 & 2 \\
\hline$n$-Propyl acetate & $\mathrm{CH}_{3} \mathrm{C}(\mathrm{O}) \mathrm{OC}_{3} \mathrm{H}_{7}$ & 3.45 & 7 & 1 & 15 & 3 \\
\hline$i$-Propyl acetate & $\mathrm{CH}_{3} \mathrm{C}(\mathrm{O}) \mathrm{OCH}\left(\mathrm{CH}_{3}\right)_{2}$ & 3.79 & 11 & 1 & 16 & 3 \\
\hline$n$-Butyl acetate & $\mathrm{CH}_{3} \mathrm{C}(\mathrm{O}) \mathrm{OC}_{4} \mathrm{H}_{9}$ & 5.66 & 7 & 1 & 14 & 2 \\
\hline \multicolumn{7}{|l|}{ Acids } \\
\hline Formic acid & $\mathrm{HC}(\mathrm{O}) \mathrm{OH}$ & 0.44 & 0.6 & 0.1 & 1.0 & 0.0 \\
\hline Acetic acid & $\mathrm{CH}_{3} \mathrm{C}(\mathrm{O}) \mathrm{OH}$ & 0.7 & 7 & 1 & 6 & 1 \\
\hline Propanoic acid & $\mathrm{CH}_{3} \mathrm{CH}_{2} \mathrm{C}(\mathrm{O}) \mathrm{OH}$ & 1.2 & 12 & 2 & 6 & 2 \\
\hline \multicolumn{7}{|l|}{ Aldehydes } \\
\hline Formaldehyde & $\mathrm{HCHO}$ & 8.5 & 119 & 11 & 78 & 20 \\
\hline Acetaldehyde & $\mathrm{CH}_{3} \mathrm{CHO}$ & 15.3 & 72 & 2 & 59 & 20 \\
\hline Propionaldehyde & $\mathrm{C}_{2} \mathrm{H}_{5} \mathrm{CHO}$ & 18.7 & 75 & 4 & 63 & 24 \\
\hline n-Butyraldehyde & $\mathrm{C}_{3} \mathrm{H}_{7} \mathrm{CHO}$ & 23.7 & 63 & 3 & 60 & 21 \\
\hline$i$-Butyraldehyde & $\left(\mathrm{CH}_{3}\right)_{2} \mathrm{CHCHO}$ & 25.6 & 56 & 3 & 60 & 18 \\
\hline 3-Methylbutanal & $\left(\mathrm{CH}_{3}\right)_{2} \mathrm{CHCH}_{2} \mathrm{CHO}$ & 25.9 & 53 & 2 & 73 & 23 \\
\hline$n$-Pentanal & $\mathrm{C}_{4} \mathrm{H}_{9} \mathrm{CHO}$ & 26.6 & 53 & 3 & 74 & 20 \\
\hline Glyoxal & $\mathrm{CHOCHO}$ & 0.9 & 160 & 20 & 60 & 16 \\
\hline Methyl glyoxal & $\mathrm{CH}_{3} \mathrm{C}(\mathrm{O}) \mathrm{CHO}$ & 13 & 209 & 27 & 163 & 44 \\
\hline Acrolein & $\mathrm{CH}_{2} \mathrm{CHCHO}$ & 21.6 & 81 & 6 & 80 & 44 \\
\hline Methacrolein & $\mathrm{CH}_{2} \mathrm{C}(\mathrm{CH})_{3} \mathrm{CHO}$ & 32 & 67 & 3 & 136 & 41 \\
\hline Benzaldehyde & $\mathrm{C}_{6} \mathrm{H}_{5} \mathrm{CHO}$ & 12.6 & -10 & 2 & -36 & 34 \\
\hline 4-Methylbenzaldehyde & $p-\mathrm{CH}_{3} \mathrm{C}_{6} \mathrm{H}_{4} \mathrm{CHO}$ & 16.8 & -9 & 2 & -36 & 43 \\
\hline 2- Methylbenzaldehyde & $o-\mathrm{CH}_{3} \mathrm{C}_{6} \mathrm{H}_{4} \mathrm{CHO}$ & 18.9 & -9 & 2 & -101 & 83 \\
\hline 3-Methylbenzaldehyde & $m-\mathrm{CH}_{3} \mathrm{C}_{6} \mathrm{H}_{4} \mathrm{CHO}$ & 16.8 & -9 & 2 & -83 & 69 \\
\hline
\end{tabular}




\begin{tabular}{|l|l|c|l|l|l|l|}
\hline Ketones & \multicolumn{5}{|l|}{} \\
\hline Acetone & $\mathrm{CH}_{3} \mathrm{C}(\mathrm{O}) \mathrm{CH}_{3}$ & 0.18 & 3.8 & 0.3 & 4.0 & 1.0 \\
\hline Methylethylketone & $\mathrm{CH}_{3} \mathrm{C}(\mathrm{O}) \mathrm{C}_{2} \mathrm{H}_{5}$ & 1.11 & 15 & 1 & 18 & 4 \\
\hline Diethylketone & $\mathrm{C}_{2} \mathrm{H}_{5} \mathrm{C}(\mathrm{O}) \mathrm{C}_{2} \mathrm{H}_{5}$ & 2 & 12 & 2 & 17 & 5 \\
\hline Cyclohexanone & $\mathrm{C}_{6} \mathrm{H}_{10} \mathrm{O}$ & 6.4 & 12 & 2 & 21 & 5 \\
\hline Methyl-i-butylketone & $\left(\mathrm{CH}_{3}\right)_{2} \mathrm{CHCH}_{2} \mathrm{C}(\mathrm{O}) \mathrm{CH}_{3}$ & 12.8 & 41 & 2 & 53 & 6 \\
\hline Diacetone alcohol & $\left(\mathrm{CH}_{3}\right)_{2} \mathrm{C}(\mathrm{OH}) \mathrm{CH}_{2} \mathrm{C}(\mathrm{O}) \mathrm{CH}_{3}$ & 3.8 & 6 & 1 & 21 & 3 \\
\hline
\end{tabular}

${ }^{\mathrm{a}} \mathrm{k}_{\mathrm{OH}}$ : rate constants of the reactions with $\mathrm{OH}$ radicals in $\mathrm{cm}^{3}$ molecule ${ }^{-1} \mathrm{~s}^{-1}$ at $298 \mathrm{~K}$ and 1 bar, data taken from Calvert et al. ${ }^{8}$

${ }^{\mathrm{b}}$ from Derwent et al. ${ }^{226}$

${ }^{c}$ s.d.: standard deviation

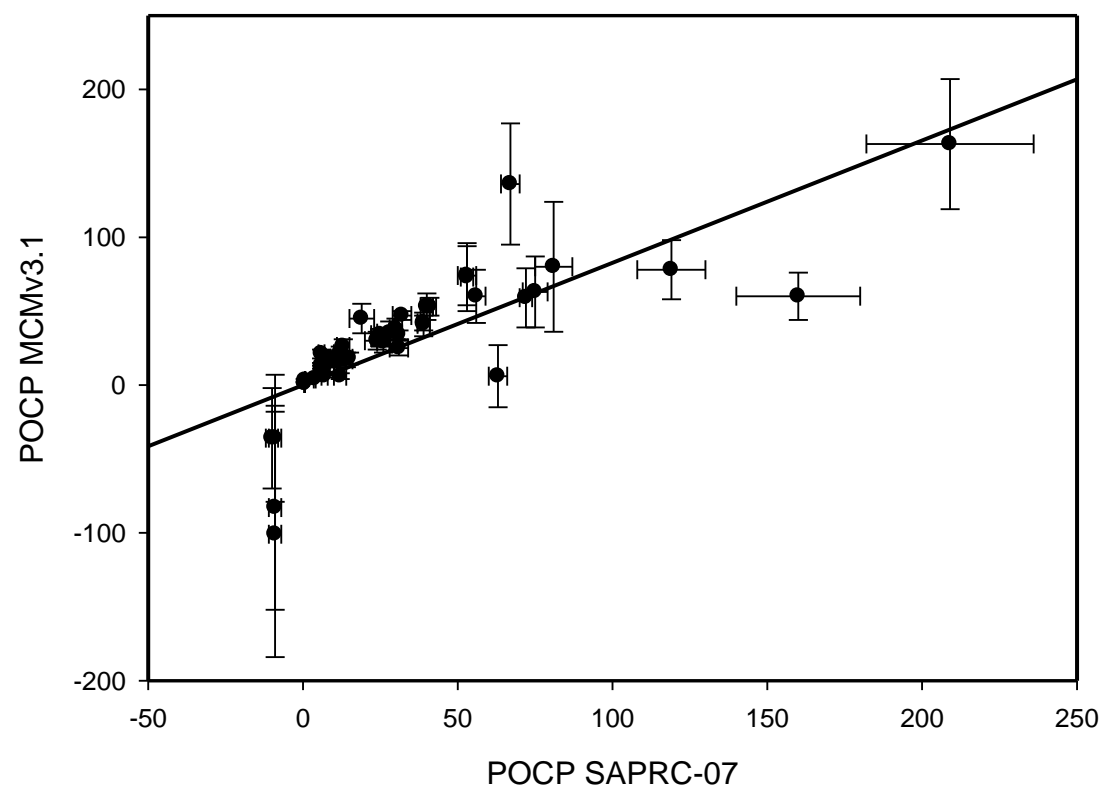


Figure 12. POCPs for oxygenated VOCs calculated using SAPRC-07 and MCMv3.1 with a regression line forced through the origin (from Derwent et al. ${ }^{226}$ )

\section{Radiative efficiencies and global warming potentials of OVOCs}

As shown in Figure 1, the five most abundant OVOCs in the atmosphere are $\mathrm{CH}_{3} \mathrm{OH}$, $\mathrm{CH}_{3} \mathrm{C}(\mathrm{O}) \mathrm{CH}_{3}, \mathrm{CH}_{3} \mathrm{OOH}, \mathrm{HCHO}$, and $\mathrm{CH}_{3} \mathrm{CHO}$. Estimates of the radiative efficiency (RE) and the global warming potential (GWP) for these molecules are not available. We have used the IR spectra of these molecules measured during studies of their atmospheric chemistry at the Ford Motor Company ${ }^{227-229}$ to estimate their REs and GWPs. The apparatus consists of a Mattson Instruments Sirius Fourier transform infrared spectrometer coupled to a 140 liter, 2 meter long, evacuable Pyrex chamber and a narrow band MCT detector. ${ }^{230}$ Internal White type multiple reflection optics provide a path length of 27.4 meters. The spectrometer was operated at a spectral resolution of $0.25 \mathrm{~cm}^{-1}$ over the spectral range of $650-3500 \mathrm{~cm}^{-1}$. Samples of the OVOCs were obtained from commercial sources at stated purities $>99.9 \%$ and were subjected to repeated freeze-pump-thaw cycling to remove volatile impurities. Mixtures of the OVOCs were made up with 700 Torr of air at $295 \mathrm{~K}$ and introduced into the chamber and their concentrations were adjusted such that the absorption features were unsaturated. IR spectra over the range 750$1850 \mathrm{~cm}^{-1}$ are presented in Figure 13. As discussed above, the lifetimes of these OVOCs are 
approximately 13 days, 18 days, 2 days, 11 hours, and 7.3 hours. Using the method described by Hodnebrog et al. $2013{ }^{122}$ radiative efficiencies for a constant vertical profile were determined for $\mathrm{CH}_{3} \mathrm{OH}, \mathrm{CH}_{3} \mathrm{C}(\mathrm{O}) \mathrm{CH}_{3}, \mathrm{CH}_{3} \mathrm{OOH}, \mathrm{HCHO}$, and $\mathrm{CH}_{3} \mathrm{CHO}$, respectively. Results are given in Table 10. Applying the lifetime correction proposed by (Hodnebrog et al. 2013) ${ }^{122}$ to account for non-uniform mixing in the atmosphere gives the effective radiative efficiencies listed in Table 10. Finally, combining these values with the atmospheric lifetimes gives GWP values for 20 and 100 year time horizons (see Acknowledgement). As seen from the results in Table 10, the direct contribution of these compounds to radiative forcing of climate is negligible.

Table 10: Integrated absorption cross sections, radiative efficiencies, and global warming potentials of $\mathrm{CH}_{3} \mathrm{OH}, \mathrm{CH}_{3} \mathrm{C}(\mathrm{O}) \mathrm{CH}_{3}, \mathrm{CH}_{3} \mathrm{OOH}, \mathrm{HCHO}$, and $\mathrm{CH}_{3} \mathrm{CHO}$.

\begin{tabular}{|l|l|l|l|l|l|l|}
\hline Compound & $\begin{array}{l}\text { Integrated } \\
\text { absorption cross } \\
\text { section }(750-1850 \\
\left.\mathrm{cm}^{-1}\right)\left(10^{-17} \mathrm{~cm}^{2}\right. \\
\text { molecule }\end{array}$ & Lifetime & $\begin{array}{l}\text { Radiative } \\
\text { efficiency } \\
\left(\mathrm{W} \mathrm{m}^{-1} \mathrm{ppb}^{-1}\right) \\
\text { constant } \\
\text { profile }\end{array}$ & $\begin{array}{l}\text { Radiative } \\
\text { efficiency }(\mathrm{W} \\
\left.\mathrm{m}^{-2} \mathrm{ppb}^{-1}\right) \text { after } \\
\text { lifetime } \\
\text { correction }\end{array}$ & $\begin{array}{l}\text { GWP } \\
(20 \text { year } \\
\text { time } \\
\text { horizon })\end{array}$ & $\begin{array}{l}\text { GWP } \\
(100 \\
\text { year time } \\
\text { horizon })\end{array}$ \\
\hline $\mathrm{CH}_{3} \mathrm{OH}$ & 1.98 & 13.0 days & 0.033 & 0.004 & 1 & 0 \\
\hline $\mathrm{CH}_{3} \mathrm{C}(\mathrm{O}) \mathrm{CH}_{3}$ & 4.80 & 18.0 days & 0.020 & 0.003 & 1 & 0 \\
\hline $\mathrm{CH}_{3} \mathrm{OOH}$ & 1.58 & 2.0 days & 0.016 & 0.000 & 0 & 0 \\
\hline $\mathrm{HCHO}$ & 1.73 & 0.5 days & 0.001 & 0.000 & 0 & 0 \\
\hline $\mathrm{CH}_{3} \mathrm{CHO}$ & 3.36 & 0.3 days & 0.010 & 0.000 & 0 & 0 \\
\hline
\end{tabular}




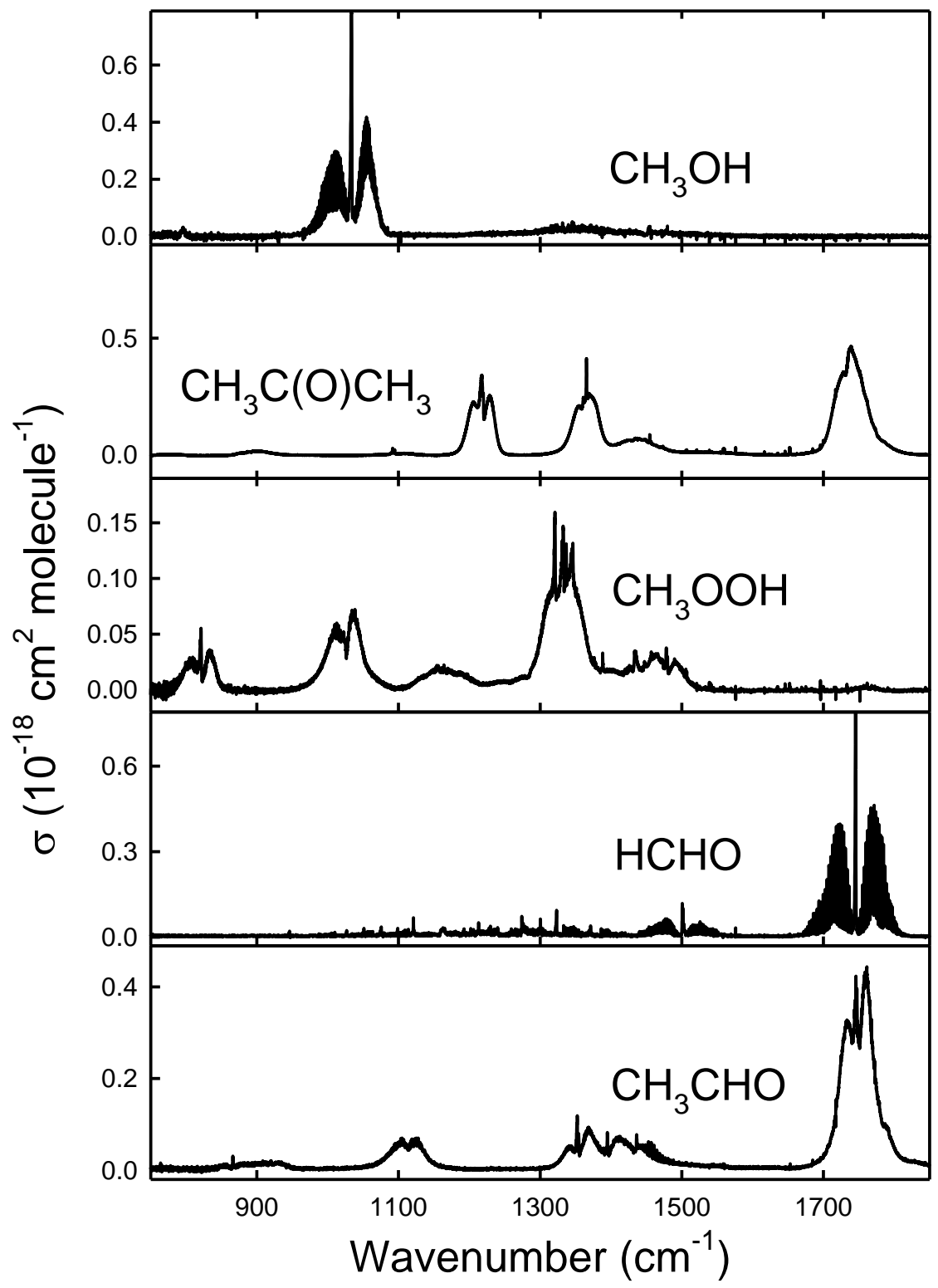

Figure 13: IR spectra for the five most abundant OVOCs in the atmosphere measured in 700 Torr of air at $296 \mathrm{~K}$. 


\section{Conclusions}

Oxygenated volatile organic compounds are present in the atmosphere as a result of anthropogenic and natural emissions and the in-situ degradation of hydrocarbons. Most OVOCs are removed rapidly via physical and chemical processes in the lower troposphere and have short atmospheric lifetimes (minutes to days). With such short lifetimes OVOCs generally have negligibly small GWPs and do not contribute to radiative forcing of climate change. Fluorinated OVOCs are an exception. The $\mathrm{C}-\mathrm{F}$ bond is exceptionally strong and generally unreactive in atmospheric reactions, additionally the presence of fluorine substituents in organic compounds increases the strength, and decreases the reactivity, of the remaining $\mathrm{C}-\mathrm{H}$ bonds in the molecule. Fluorination of OVOCs leads to a substantial decrease in reactivity towards $\mathrm{OH}$ radicals and increase in atmospheric lifetimes. In the extreme case the perfluorination of saturated OVOCs results in molecules which do not react with $\mathrm{OH}$ radicals at all. Fortunately, there are atmospheric loss mechanisms other than reaction with $\mathrm{OH}$ which limit the lifetime, and hence GWPs, of most classes of perfluoro-OVOCs. Perfluoroalcohols undergo heterogeneous decomposition via elimination of HF on a time scale of weeks. ${ }^{231-232}$ Perfluoroaldehydes and ketones undergo photolysis on a time scale of days to weeks. ${ }^{8}$ Perfluoroesters undergo hydrolysis and are removed from the atmosphere on a time scale of months. ${ }^{127}$ Short-chain perfluoroacids are highly soluble, long-chain perfluoroacids are surfactants, perfluoroacids are incorporated into 
rain-cloud-sea water and removed from the atmosphere on a time scale of weeks. ${ }^{233}$ Perfluoroethers do not decompose, hydrolyze, and are not water soluble. ${ }^{124}$ Perfluoroethers are removed from the atmosphere by photolysis at wavelengths $<200 \mathrm{~nm}$. The atmospheric lifetime of perfluoroethers is of the order of centuries and is dictated by the time taken for transport to altitudes above approximately $80 \mathrm{~km}$ where sufficient UV radiation at wavelengths $<200 \mathrm{~nm}$ is available. With the exception of a few fluorinated ethers, OVOCs have no direct effect on climate.

Although the direct effect of OVOCs on climate is very limited, their indirect effect is substantial. OVOCs are intimately involved in the sequence of photochemical reactions leading to tropospheric ozone formation. Tropospheric ozone is an important greenhouse gas, responsible for approximately $17 \%$ of the the total anthropogenic radiative forcing since 1750 of $2.29 \mathrm{~W} \mathrm{~m}^{-2} \cdot{ }^{4}$ Ozone is an extraordinarily important species in atmospheric chemistry. Ozone photolysis leads to the formation of $\mathrm{OH}$ radicals whose subsequent reactions determine the atmospheric lifetimes of most species in the atmosphere. The chemistry of OVOCs influences the atmospheric oxidation capacity. Reliable laboratory data are necessary to refine and improve atmospheric photochemical models used to describe tropospheric ozone formation and MIR and POCP indices used to rank the reactivity of VOC emissions. The use of new chemicals as substitutes requires substantial and continuous efforts from the atmospheric research community 
to keep confidence in the ability to reproduce the changes in tropospheric ozone associated with changes in type of emissions and hence on the impact on climate.

The oxidation of OVOCs produces multifunctional oxygenated compounds with low volatilities which partition into the aerosol phase. Oxygenated organic compounds including sulfur- and nitrogen-containing oxygenated organic compounds are ubiquitous components of tropospheric aerosols. Aerosols scatter incoming solar radiation and absorb outgoing long-wave radiation and play an important role in climate. Aerosols are also important in terms of visibility degradation and potential human health impacts. The chemistry leading to the formation of these aerosols is an area of active research but is still relatively poorly understood.

Gas-, liquid- and heterogeneous-phase reactions of oxygenated organic compounds are of central importance to atmospheric chemistry and to understanding the impact of anthropogenic emissions on air quality and climate. Much has been learned over the past 50 years of the chemistry of oxygenated organic compounds, but much is yet to be discovered. 


\section{Acknowledgments}

The Labex Voltaire (ANR-10-LABX-100-01), the IRSES-EU Marie Curie Actions project “AMIS" (PIRSES-GA-2011-295132) the National Natural Science Foundation of China (No. 21190053) for support and Taishan Scholar Grant (ts20120552). We thank Øivind Hodnebrog for calculating the REs and GWPs for $\mathrm{CH}_{3} \mathrm{OH}, \mathrm{CH}_{3} \mathrm{C}(\mathrm{O}) \mathrm{CH}_{3}, \mathrm{CH}_{3} \mathrm{OOH}, \mathrm{HCHO}$, and $\mathrm{CH}_{3} \mathrm{CHO}$ shown in Table 10. While this article is believed to contain correct information, Ford Motor Company (Ford) does not expressly or impliedly warrant, nor assume any responsibility, for the accuracy, completeness, or usefulness of any information, apparatus, product, or process disclosed, nor represent that its use would not infringe the rights of third parties. Reference to any commercial product or process does not constitute its endorsement. This article does not provide financial, safety, medical, consumer product, or public policy advice or recommendation. Readers should independently replicate all experiments, calculations, and results. The views and opinions expressed are of the authors and do not necessarily reflect those of Ford. This disclaimer may not be removed, altered, superseded or modified without prior Ford permission. 


\section{References:}

(1) Royal-Society Ground-level ozone in the 21st century: future trends, impacts and policy implications; RS Policy document 15/08 ed.; The Royal Society: London, 2008.

(2) Wild, O. Atmospheric Chemistry and Physics 2007, 7, 2643.

(3) Kiehl, J. T.; Trenberth, K. E. Bulletin of the American Meteorological Society 1997, 78, 197.

(4) IPCC "Climate change 2013: The physical science basis," Intergovernmental Panel on Climate Change, 2013.

(5) Derwent, R. G.; Jenkin, M. E.; Saunders, S. M.; Pilling, M. J. Atmospheric Environment 1998, 32, 2429.

(6) Jenkin, M. E. "Photochemical ozone and PAN creation potentials: rationalisation and methods of estimation, AEA Technology plc, Report AEAT-4182/ 20150/003, AEA Technology plc, National Environmental Technology Centre, Culham, Oxfordshire OX14 3DB, UK," 1998.

(7) Atkinson, R.; Arey, J. Chemical Reviews 2003, 103, 4605.

(8) Calvert, J. G.; Mellouki, A.; Orlando, J. J.; Pilling, M. J.; Wallington, T. J. The Mechanisms of Atmospheric Oxidation of the Oxygenates; Oxford University Press: New York, 2011.

(9) Mellouki, A.; Le Bras, G.; Sidebottom, H. Chemical Reviews 2003, 103, 5077.

(10) Wallington, T. J.; Dagaut, P.; Kurylo, M. J. Chemical Reviews 1992, 92, 667. 
(11) Tyndall, G. S.; Cox, R. A.; Granier, C.; Lesclaux, R.; Moortgat, G. K.; Pilling, M. J.; Ravishankara, A. R.; Wallington, T. J. Journal of Geophysical Research-Atmospheres 2001, 106, 12157.

(12) Guenther, A. B.; Jiang, X.; Heald, C. L.; Sakulyanontvittaya, T.; Duhl, T.; Emmons, L. K.; Wang, X. Geoscientific Model Development 2012, 5, 1471.

(13) Peeters, J.; Nguyen, T. L.; Vereecken, L. Physical Chemistry Chemical Physics 2009, 11, 5935.

(14) Crounse, J. D.; Paulot, F.; Kjaergaard, H. G.; Wennberg, P. O. Physical Chemistry Chemical Physics 2011, 13, 13607.

(15) Taraborrelli, D.; Lawrence, M. G.; Butler, T. M.; Sander, R.; Lelieveld, J. Atmospheric Chemistry and Physics 2009, 9, 2751.

(16) Fall, R. Chemical Reviews 2003, 103, 4941.

(17) Methanol-Institute; $\quad$ http://www.methanol.org/getattachment/827c8c64-fb2a-4520-aa5a210612b903cd/MMSA-Supply---Demand-Tables-2008---2013.pdf.aspx, downloaded June 2014.

(18) Kimmerer, T. W.; Macdonald, R. C. Plant Physiology 1987, 84, 1204.

(19) Kreuzwieser, J.; Papadopoulou, E.; Rennenberg, H. Plant Biology 2004, 6, 299.

(20) Macdonald, R. C.; Kimmerer, T. W. Plant Physiology 1993, 102, 173.

(21) Kirstine, W. V.; Galbally, I. E. Atmospheric Chemistry and Physics 2012, 12, 545.

(22) Energy-Information-Administration-(2012) “Annual Energy Review 2011, Washington, DC, DOE/EIA-0384," 2011. 
(23) Kirin-University-Beer-Report-2012

“http://www.kirinholdings.co.jp/english/news/2013/0822 01.html, downloaded August 2014."

(24) Wine-Institute-2014; http://www.wineinstitute.org/resources/statistics, downloaded August 2014.

(25) Kirstine, W. V.; Galbally, I. E. Critical Reviews in Environmental Science and Technology 2012, 42, 1735.

(26) U.S.-Department-of-Energy; Alternative-Fuels-Data-Center, http://www.afdc.energy.gov/fuels/, downloaded August 2014

(27) Murrells, T. P. “National Atmospheric Emission Inventory, VOC Speciation,” 2009.

(28) Oderbolz, D. C.; Aksoyoglu, S.; Keller, J.; Barmpadimos, I.; Steinbrecher, R.; Skjoth, C. A.; PlassDulmer, C.; Prevot, A. S. H. Atmospheric Chemistry and Physics 2013, 13, 1689.

(29) Methanol Institute http://www.methanol.org/, 2014.

(30) Murrells, T. P. Private communication 2014.

(31) Wallington, T. J.; Kaiser, E. W.; Farrell, J. T. Chemical Society Reviews 2006, 35, 335.

(32) Hubbard, C. P.; Anderson, J. E.; Wallington, T. J. Environmental Science \& Technology 2014, 48, 861.

(33) Singh, H.; Chen, Y.; Staudt, A.; Jacob, D.; Blake, D.; Heikes, B.; Snow, J. Nature 2001, 410, 1078. 
(34) Singh, H.; Chen, Y.; Tabazadeh, A.; Fukui, Y.; Bey, I.; Yantosca, R.; Jacob, D.; Arnold, F.; Wohlfrom, K.; Atlas, E.; Flocke, F.; Blake, D.; Blake, N.; Heikes, B.; Snow, J.; Talbot, R.; Gregory, G.; Sachse, G.; Vay, S.; Kondo, Y. Journal of Geophysical Research-Atmospheres 2000, 105, 3795.

(35) Kiendler, A.; Arnold, F. International Journal of Mass Spectrometry 2003, 223, 733.

(36) Sander, R.; Compilation of Henry's law constants for inorganic and organic species of potential importance in environmental chemistry (Version 3), http://www.henrys-law.org/henry-3.0.pdf, downloaded August 2014., 1999.

(37) Atkinson, R.; Baulch, D. L.; Cox, R. A.; Crowley, J. N.; Hampson, R. F.; Hynes, R. G.; Jenkin, M. E.; Rossi, M. J.; Troe, J. Atmospheric Chemistry and Physics 2006, 6, 3625.

(38) Derwent, R. G.; Jenkin, M. E.; Passant, N. R.; Pilling, M. J. Environmental Science \& Policy 2007, $10,445$.

(39) Meylan, W. M.; Howard, P. H. Environmental Toxicology and Chemistry 1991, 10, 1283.

(40) von Kuhlmann, R.; Lawrence, M. G.; Crutzen, P. J.; Rasch, P. J. Journal of Geophysical ResearchAtmospheres 2003, 108, 4729.

(41) Calvert, J. G.; Derwent, R. G.; Orlando, J. J.; Tyndall, G. S.; Wallington, T. J. The mechanisms of atmospheric oxidation of the alkenes; Oxford University Press New York, 2008.

(42) Chew, A. A.; Atkinson, R. Journal of Geophysical Research: Atmospheres 1996, 101, 28649.

(43) Baxley, J. S.; Wells, J. R. International Journal of Chemical Kinetics 1998, 30, 745. 
(44) Aschmann, S. M.; Atkinson, R. International Journal of Chemical Kinetics 1998, 30, 533.

(45) Bethel, H. L.; Atkinson, R.; Arey, J. International Journal of Chemical Kinetics 2001, 33, 310.

(46) Magneron, I.; Bossoutrot, V.; Mellouki, A.; Laverdet, G.; Le Bras, G. Environmental Science \& Technology 2003, 37, 4170.

(47) Bradley, W. R.; Wyatt, S. E.; Wells, J. R.; Henley, M. V.; Graziano, G. M. International Journal of Chemical Kinetics 2001, 33, 108.

(48) Thüner, L. P.; Bardini, P.; Rea, G. J.; Wenger, J. C. The Journal of Physical Chemistry A 2004, 108, 11019.

(49) Atkinson, R.; Aschmann, S. M. Int. J. Chem. Kinet. 1990, 22, 59.

(50) Orlando, J. J.; Tyndall, G. S.; Ceazan, N. Journal of Physical Chemistry A 2001, 105, 3564.

(51) Alvarado, A.; Tuazon, E. C.; Aschmann, S. M.; Arey, J.; Atkinson, R. Atmospheric Environment 1999, 33, 2893.

(52) Ferronato, C.; Orlando, J. J.; Tyndall, G. S. Journal of Geophysical Research-Atmospheres 1998, $103,25579$.

(53) Carrasco, N.; Doussin, J. F.; O'Connor, M.; Wenger, J. C.; Picquet-Varrault, B.; Durand-Jolibois, R.; Carlier, P. Journal of Atmospheric Chemistry 2007, 56, 33.

(54) Grosjean, D.; Grosjean, E.; Williams, E. L. Environmental Science \& Technology 1993, 27, 2478.

(55) Grosjean, E.; Grosjean, D. Journal of Atmospheric Chemistry 1999, 32, 205. 
(56) Le Person, A.; Solignac, G.; Oussar, F.; Daele, V.; Mellouki, A.; Winterhalter, R.; Moortgat, G. K. Physical Chemistry Chemical Physics 2009, 11, 7619.

(57) Noda, J.; Hallquist, M.; Langer, S.; Ljungstrom, E. Physical Chemistry Chemical Physics 2000, 2, 2555.

(58) Noda, J.; Nyman, G.; Langer, S. Journal of Physical Chemistry A 2002, 106, 945.

(59) Ammann, M.; Cox, R. A.; Crowley, J. N.; Jenkin, M. E.; Mellouki, A.; Rossi, M. J.; Troe, J.; Wallington, T. J. Report on the 34th Session of the Joint Scientific Committee of the World Climate Research Programme 2014.

(60) Wallington, T. J.; Japar, S. M. Environmental Science \& Technology 1991, 25, 410.

(61) Eberhard, J.; Muller, C.; Stocker, D. W.; Kerr, J. A. International Journal of Chemical Kinetics $1993,25,639$.

(62) Cheema, S. A.; Holbrook, K. A.; Oldershaw, G. A.; Starkey, D. P.; Walker, R. W. Physical Chemistry Chemical Physics 1999, 1, 3243.

(63) Orlando, J. J. Physical Chemistry Chemical Physics 2007, 9, 4189.

(64) Wallington, T. J.; Hurley, M. D.; Ball, J. C.; Straccia, A. M.; Platz, J.; Christensen, L. K.; Sehested, J.; Nielsen, O. J. Journal of Physical Chemistry A 1997, 101, 5302.

(65) Wenger, J.; Porter, E.; Collins, E.; Treacy, J.; Sidebottom, H. Chemosphere 1999, 38, 1197.

(66) Geiger, H.; Becker, K. H. Atmospheric Environment 1999, 33, 2883. 
(67) Sauer, C. G.; Barnes, I.; Becker, K. H.; Geiger, H.; Wallington, T. J.; Christensen, L. K.; Platz, J.; Nielsen, O. J. Journal of Physical Chemistry A 1999, 103, 5959.

(68) Thiault, G.; Thevenet, R.; Mellouki, A.; Le Bras, G. Physical Chemistry Chemical Physics 2002, 4, 613.

(69) Thiault, G.; Mellouki, A. Atmospheric Environment 2006, 40, 5566.

(70) Zhou, S. M.; Barnes, I.; Zhu, T.; Bejan, I.; Benter, T. Journal of Physical Chemistry A 2006, 110, 7386.

(71) Zhou, S. M.; Barnes, I.; Zhu, T.; Benter, T. Journal of Physical Chemistry A 2009, 113, 858.

(72) Klotz, B.; Barnes, I.; Imamura, T. Physical Chemistry Chemical Physics 2004, 6, 1725.

(73) Scarfogliero, M.; Picquet-Varrault, B.; Salce, J.; Durand-Jolibois, R.; Doussin, J. F. Journal of Physical Chemistry A 2006, 110, 11074.

(74) Zhou, S. M.; Barnes, I.; Zhu, T.; Klotz, B.; Bejan, M.; Benter, T. Environmental Science \& Technology 2006, 40, 5415.

(75) Sadezky, A.; Chaimbault, P.; Mellouki, A.; Rompp, A.; Winterhalter, R.; Le Bras, G.; Moortgat, G. K. Atmospheric Chemistry and Physics 2006, 6, 5009.

(76) Sadezky, A.; Winterhalter, R.; Kanawati, B.; Rompp, A.; Spengler, B.; Mellouki, A.; Le Bras, G.; Chaimbault, P.; Moortgat, G. K. Atmospheric Chemistry and Physics 2008, 8, 2667.

(77) Meller, R.; Moortgat, G. K. Journal of Geophysical Research-Atmospheres 2000, 105, 7089. 
(78) Andrews, D. U.; Heazlewood, B. R.; Maccarone, A. T.; Conroy, T.; Payne, R. J.; Jordan, M. J. T.; Kable, S. H. Science 2012, 337, 1203.

(79) Archibald, A. T.; McGillen, M. R.; Taatjes, C. A.; Percival, C. J.; Shallcross, D. E. Geophysical Research Letters 2007, 34, n/a.

(80) D'Anna, B.; Wisthaler, A.; Andreasen, O.; Hansel, A.; Hjorth, J.; Jensen, N. R.; Nielsen, C. J.; Stenstrom, Y.; Viidanoja, J. Journal of Physical Chemistry A 2005, 109, 5104.

(81) Clifford, G. M.; Hadj-Aissa, A.; Healy, R. M.; Mellouki, A.; Munoz, A.; Wirtz, K.; Reviejo, M. M.; Borras, E.; Wenger, J. C. Environmental Science \& Technology 2011, 45, 9649.

(82) O'Connor, M. P.; Wenger, J. C.; Mellouki, A.; Wirtz, K.; Munoz, A. Physical Chemistry Chemical Physics 2006, 8, 5236.

(83) Tuazon, E. C.; Atkinson, R. International Journal of Chemical Kinetics 1990, 22, 591.

(84) Orlando, J. J.; Tyndall, G. S.; Paulson, S. E. Geophysical Research Letters 1999, 26, 2191.

(85) Orlando, J. J.; Tyndall, G. S. Journal of Physical Chemistry A 2002, 106, 12252.

(86) Magneron, I.; Thevenet, R.; Mellouki, A.; Le Bras, G.; Moortgat, G. K.; Wirtz, K. Journal of Physical Chemistry A 2002, 106, 2526.

(87) Salgado, M. S.; Monedero, E.; Villanueva, F.; Martin, P.; Tapia, A.; Cabanas, B. Environmental Science \& Technology 2008, 42, 2394. 
(88) Clifford, G. M.; Thüner, L. P.; Wenger, J. C.; Shallcross, D. E. Journal of Photochemistry and Photobiology A: Chemistry 2005, 176, 172.

(89) Clifford, G. M.; Hadj-Aïssa, A.; Healy, R. M.; Mellouki, A.; Muñoz, A.; Wirtz, K.; Martín Reviejo, M.; Borrás, E.; Wenger, J. C. Environmental Science \& Technology 2011, 45, 9649.

(90) Atkinson, R.; Arey, J.; Aschmann, S. M. Atmospheric Environment 2008, 42, 5859.

(91) Baker, J.; Arey, J.; Atkinson, R. Journal of Photochemistry and Photobiology a-Chemistry 2005, $176,143$.

(92) Calvert, J. G.; Pitts Jr, J. N. Photochemistry; John Wiley and Sons, New York, 1966.

(93) Martinez, R. D.; Buitrago, A. A.; Howell, N. W.; Hearn, C. H.; Joens, J. A. Atmospheric Environment. Part A. General Topics 1992, 26, 785.

(94) Mu, Y. J.; Mellouki, A. Journal of Photochemistry and Photobiology a-Chemistry 2000, 134, 31.

(95) Gierczak, T.; Burkholder, J. B.; Bauerle, S.; Ravishankara, A. R. Chemical Physics 1998, 231, 229.

(96) Blitz, M. A.; Heard, D. E.; Pilling, M. J.; Arnold, S. R.; Chipperfield, M. P. Geophysical Research Letters 2004, 31.

(97) Blitz, M. A.; Heard, D. E.; Pilling, M. J. Journal of Physical Chemistry A 2006, 110, 6742.

(98) Atkinson, R.; Aschmann, S. M.; Carter, W. P. L.; Pitts, J. N. International Journal of Chemical Kinetics 1982, 14, 839.

(99) Le Calve, S.; Hitier, D.; Le Bras, G.; Mellouki, A. Journal of Physical Chemistry A 1998, 102, 4579. 
(100) Orlando, J. J.; Tyndall, G. S.; Vereecken, L.; Peeters, J. Journal of Physical Chemistry A 2000, 104, 11578.

(101) Atkinson, R.; Tuazon, E. C.; Aschmann, S. M. Environmental Science \& Technology 2000, 34, 623.

(102) Bierbach, A.; Barnes, I.; Becker, K. H.; Wiesen, E. Environmental Science \& Technology 1994, 28, 715.

(103) Liu, X. Y.; Jeffries, H. E.; Sexton, K. G. Environmental Science \& Technology 1999, 33, 4212.

(104) Tuazon, E. C.; Atkinson, R. Environmental Science \& Technology 2003, 37, 3339.

(105) Wiesen, E.; Barnes, I.; Becker, K. H. Environmental Science \& Technology 1995, 29, 1380.

(106) Tuazon, E. C.; Aschmann, S. M.; Atkinson, R.; Carter, W. P. L. Journal of Physical Chemistry A $1998,102,2316$.

(107) Liang, P.; Mu, Y. J.; Daele, V.; Mellouki, A. Chemphyschem 2010, 11, 4097.

(108) Glasius, M.; Lahaniati, M.; Calogirou, A.; Di Bella, D.; Jensen, N. R.; Hjorth, J.; Kotzias, D.; Larsen, B. R. Environmental Science \& Technology 2000, 34, 1001.

(109) Orzechowska, G. E.; Nguyen, H. T.; Paulson, S. E. Journal of Physical Chemistry A 2005, 109, 5366.

(110) Orzechowska, G. E.; Paulson, S. E. Journal of Physical Chemistry A 2005, 109, 5358.

(111) Presto, A. A.; Hartz, K. E. H.; Donahue, N. M. Environmental Science \& Technology 2005, 39, 7036. 
(112) Ervens, B.; Feingold, G.; Frost, G. J.; Kreidenweis, S. M. Journal of Geophysical ResearchAtmospheres 2004, 109.

(113) Brasseur, G. P.; Orlando, J. J.; Tyndall, G. S. Atmospheric chemistry and global change; Oxford University Press: Oxford, UK, 1999.

(114) Seinfeld, J. H.; Pandis, S. N. Atmospheric Chemistry and Physics: From Air Pollution to Climate Change, 2nd Edition; Wiley, 2006.

(115) Bilde, M.; Svenningsson, B.; Monster, J.; Rosenorn, T. Environmental Science \& Technology 2003, $37,1371$.

(116) Cappa, C. D.; Lovejoy, E. R.; Ravishankara, A. R. Journal of Physical Chemistry A 2007, 111, 3099.

(117) Saxena, P.; Hildemann, L. M. Journal of Atmospheric Chemistry 1996, 24, 57.

(118) Mellouki, A.; Mu, Y. J. Journal of Photochemistry and Photobiology a-Chemistry 2003, 157, 295.

(119) Bilde, M.; Pandis, S. N. Environmental Science \& Technology 2001, 35, 3344.

(120) Khan, I.; Brimblecombe, P.; Clegg, S. L. Journal of Atmospheric Chemistry 1995, 22, 285.

(121) Johnson, B. J.; Betterton, E. A.; Craig, D. Journal of Atmospheric Chemistry 1996, 24, 113.

(122) Hodnebrog, O.; Etminan, M.; Fuglestvedt, J. S.; Marston, G.; Myhre, G.; Nielsen, C. J.; Shine, K. P.; Wallington, T. J. Reviews of Geophysics 2013, 51, 300.

(123) Ravishankara, A. R.; Solomon, S.; Turnipseed, A. A.; Warren, R. F. Science 1993, 259, 194. 
(124) Young, C. J.; Hurley, M. D.; Wallington, T. J.; Mabury, S. A. Environmental Science \& Technology 2006, 40, 2242.

(125) D'Anna, B.; Sellevag, S. R.; Wirtz, K.; Nielsen, C. J. Environmental Science \& Technology 2005, 39, 8708.

(126) Taniguchi, N.; Wallington, T. J.; Hurley, M. D.; Guschin, A. G.; Molina, L. T.; Molina, M. J. Journal of Physical Chemistry A 2003, 107, 2674.

(127) Kutsuna, S.; Chen, L.; Abe, T.; Mizukado, J.; Uchimaru, T.; Tokuhashi, K.; Sekiya, A. Atmospheric Environment 2005, 39, 5884.

(128) Kutsuna, S.; Chen, L.; Ohno, K.; Tokuhashi, K.; Sekiya, A. Atmospheric Environment 2004, 38, 725.

(129) Blando, J. D.; Porcja, R. J.; Li, T. H.; Bowman, D.; Lioy, P. J.; Turpin, B. J. Environmental Science \& Technology 1998, 32, 604.

(130) Romero, F.; Oehme, M. Journal of Atmospheric Chemistry 2005, 52, 283.

(131) Reemtsma, T.; These, A.; Venkatachari, P.; Xia, X. Y.; Hopke, P. K.; Springer, A.; Linscheid, M. Analytical Chemistry 2006, 78, 8299.

(132) Farmer, D. K.; Matsunaga, A.; Docherty, K. S.; Surratt, J. D.; Seinfeld, J. H.; Ziemann, P. J.; Jimenez, J. L. Proceedings of the National Academy of Sciences of the United States of America 2010, 107, 6670 . 
(133) Mazzoleni, L. R.; Ehrmann, B. M.; Shen, X. H.; Marshall, A. G.; Collett, J. L. Environmental Science \& Technology 2010, 44, 3690.

(134) Altieri, K. E.; Turpin, B. J.; Seitzinger, S. P. Environmental Science \& Technology 2009, 43, 6950.

(135) Pratt, K. A.; Fiddler, M. N.; Shepson, P. B.; Carlton, A. G.; Surratt, J. D. Atmospheric Environment 2013, 77, 231.

(136) Zhao, Y.; Hallar, A. G.; Mazzoleni, L. R. Atmospheric Chemistry and Physics 2013, 13, 12343.

(137) Lin, P.; Yu, J. Z.; Engling, G.; Kalberer, M. Environmental Science \& Technology 2012, 46, 13118.

(138) Stone, E. A.; Yang, L. M.; Yu, L. Y. E.; Rupakheti, M. Atmospheric Environment 2012, 47, 323.

(139) Kristensen, K.; Glasius, M. Atmospheric Environment 2011, 45, 4546.

(140) Liggio, J.; Li, S. M.; McLaren, R. Environmental Science \& Technology 2005, 39, 1532.

(141) Liggio, J.; Li, S. M. Geophysical Research Letters 2006, 33.

(142) Minerath, E. C.; Casale, M. T.; Elrod, M. J. Environmental Science \& Technology 2008, 42, 4410.

(143) Schmitt-Kopplin, P.; Gelencser, A.; Dabek-Zlotorzynska, E.; Kiss, G.; Hertkorn, N.; Harir, M.; Hong, Y.; Gebefugi, I. Analytical Chemistry 2010, 82, 8017.

(144) Nguyen, T. B.; Lee, P. B.; Updyke, K. M.; Bones, D. L.; Laskin, J.; Laskin, A.; Nizkorodov, S. A. Journal of Geophysical Research-Atmospheres 2012, 117. 
(145) Schwartz, R. E.; Russell, L. M.; Sjostedt, S. J.; Vlasenko, A.; Slowik, J. G.; Abbatt, J. P. D.;

Macdonald, A. M.; Li, S. M.; Liggio, J.; Toom-Sauntry, D.; Leaitch, W. R. Atmospheric Chemistry and Physics 2010, 10, 5075.

(146) Frossard, A. A.; Shaw, P. M.; Russell, L. M.; Kroll, J. H.; Canagaratna, M. R.; Worsnop, D. R.; Quinn, P. K.; Bates, T. S. Journal of Geophysical Research-Atmospheres 2011, 116.

(147) Tolocka, M. P.; Turpin, B. Environmental Science \& Technology 2012, 46, 7978.

(148) Lukacs, H.; Gelencser, A.; Hoffer, A.; Kiss, G.; Horvath, K.; Hartyani, Z. Atmospheric Chemistry and Physics 2009, 9, 231.

(149) Surratt, J. D.; Gomez-Gonzalez, Y.; Chan, A. W. H.; Vermeylen, R.; Shahgholi, M.; Kleindienst, T. E.; Edney, E. O.; Offenberg, J. H.; Lewandowski, M.; Jaoui, M.; Maenhaut, W.; Claeys, M.; Flagan, R. C.; Seinfeld, J. H. Journal of Physical Chemistry A 2008, 112, 8345.

(150) LeClair, J. P.; Collett, J. L.; Mazzoleni, L. R. Environmental Science \& Technology 2012, 46, 4312.

(151) Froyd, K. D.; Murphy, S. M.; Murphy, D. M.; de Gouw, J. A.; Eddingsaas, N. C.; Wennberg, P. O. Proceedings of the National Academy of Sciences of the United States of America 2010, 107, 21360.

(152) linuma, Y.; Boge, O.; Kahnt, A.; Herrmann, H. Physical Chemistry Chemical Physics 2009, 11, 7985. 
(153) Kundu, S.; Quraishi, T. A.; Yu, G.; Suarez, C.; Keutsch, F. N.; Stone, E. A. Atmospheric Chemistry and Physics 2013, 13, 4865.

(154) Ma, Y.; Xu, X. K.; Song, W. H.; Geng, F. H.; Wang, L. Atmospheric Environment 2014, 85, 152.

(155) Surratt, J. D.; Kroll, J. H.; Kleindienst, T. E.; Edney, E. O.; Claeys, M.; Sorooshian, A.; Ng, N. L.; Offenberg, J. H.; Lewandowski, M.; Jaoui, M.; Flagan, R. C.; Seinfeld, J. H. Environmental Science \& Technology 2007, 41, 517.

(156) Surratt, J. D.; Lewandowski, M.; Offenberg, J. H.; Jaoui, M.; Kleindienst, T. E.; Edney, E. O.; Seinfeld, J. H. Environmental Science \& Technology 2007, 41, 5363.

(157) linuma, Y.; Muller, C.; Berndt, T.; Boge, O.; Claeys, M.; Herrmann, H. Environmental Science \& Technology 2007, 41, 6678.

(158) linuma, Y.; Muller, C.; Boge, O.; Gnauk, T.; Herrmann, H. Atmospheric Environment 2007, 41, 5571.

(159) Drozd, G. T.; Woo, J. L.; McNeill, V. F. Atmospheric Chemistry and Physics 2013, 13, 8255.

(160) Kroll, J. H.; Ng, N. L.; Murphy, S. M.; Varutbangkul, V.; Flagan, R. C.; Seinfeld, J. H. Journal of Geophysical Research-Atmospheres 2005, 110.

(161) Sareen, N.; Schwier, A. N.; Shapiro, E. L.; Mitroo, D.; McNeill, V. F. Atmospheric Chemistry and Physics 2010, 10, 997. 
(162) Nguyen, T. B.; Coggon, M. M.; Bates, K. H.; Zhang, X.; Schwantes, R. H.; Schilling, K. A.; Loza, C. L.; Flagan, R. C.; Wennberg, P. O.; Seinfeld, J. H. Atmospheric Chemistry and Physics 2014, 14, 3497.

(163) Surratt, J. D.; Chan, A. W. H.; Eddingsaas, N. C.; Chan, M. N.; Loza, C. L.; Kwan, A. J.; Hersey, S. P.; Flagan, R. C.; Wennberg, P. O.; Seinfeld, J. H. Proceedings of the National Academy of Sciences of the United States of America 2010, 107, 6640.

(164) Worton, D. R.; Surratt, J. D.; LaFranchi, B. W.; Chan, A. W. H.; Zhao, Y. L.; Weber, R. J.; Park, J. H.; Gilman, J. B.; de Gouw, J.; Park, C.; Schade, G.; Beaver, M.; St Clair, J. M.; Crounse, J.; Wennberg, P.; Wolfe, G. M.; Harrold, S.; Thornton, J. A.; Farmer, D. K.; Docherty, K. S.; Cubison, M. J.; Jimenez, J. L.; Frossard, A. A.; Russell, L. M.; Kristensen, K.; Glasius, M.; Mao, J. Q.; Ren, X. R.; Brune, W.; Browne, E. C.; Pusede, S. E.; Cohen, R. C.; Seinfeld, J. H.; Goldsteint, A. H. Environmental Science \& Technology 2013, 47, 11403.

(165) Paulot, F.; Crounse, J. D.; Kjaergaard, H. G.; Kurten, A.; St Clair, J. M.; Seinfeld, J. H.; Wennberg, P. O. Science $2009,325,730$.

(166) Chan, A. W. H.; Chan, M. N.; Surratt, J. D.; Chhabra, P. S.; Loza, C. L.; Crounse, J. D.; Yee, L. D.; Flagan, R. C.; Wennberg, P. O.; Seinfeld, J. H. Atmospheric Chemistry and Physics 2010, 10, 7169.

(167) Lin, Y. H.; Zhang, H. F.; Pye, H. O. T.; Zhang, Z. F.; Marth, W. J.; Park, S.; Arashiro, M.; Cui, T. Q.; Budisulistiorini, H.; Sexton, K. G.; Vizuete, W.; Xie, Y.; Luecken, D. J.; Piletic, I. R.; Edney, E. O.; 
Bartolotti, L. J.; Gold, A.; Surratt, J. D. Proceedings of the National Academy of Sciences of the United States of America 2013, 110, 6718.

(168) Obrien, R. J.; Crabtree, J. H.; Holmes, J. R.; Hoggan, M. C.; Bockian, A. H. Environmental Science \& Technology 1975, 9, 577.

(169) Cape, J. N.; Cornell, S. E.; Jickells, T. D.; Nemitz, E. Atmospheric Research 2011, 102, 30.

(170) Cornell, S. E.; Jickells, T. D.; Cape, J. N.; Rowland, A. P.; Duce, R. A. Atmospheric Environment 2003, 37, 2173.

(171) El Haddad, I.; Marchand, N.; D'Anna, B.; Jaffrezo, J. L.; Wortham, H. Atmospheric Environment 2013, 75, 308.

(172) Pavlovic, J.; Hopke, P. K. Atmospheric Environment 2012, 59, 264.

(173) Laurent, J. P.; Allen, D. T. Aerosol Science and Technology 2004, 38, 82.

(174) Mylonas, D. T.; Allen, D. T.; Ehrman, S. H.; Pratsinis, S. E. Atmospheric Environment Part aGeneral Topics 1991, 25, 2855.

(175) Day, D. A.; Liu, S.; Russell, L. M.; Ziemann, P. J. Atmospheric Environment 2010, 44, 1970.

(176) Kahnt, A.; Behrouzi, S.; Vermeylen, R.; Shalamzari, M. S.; Vercauteren, J.; Roekens, E.; Claeys, M.; Maenhaut, W. Atmospheric Environment 2013, 81, 561.

(177) Altieri, K. E.; Hastings, M. G.; Peters, A. J.; Sigman, D. M. Atmospheric Chemistry and Physics 2012, 12, 3557. 
(178) Bleier, D. B.; Elrod, M. J. Journal of Physical Chemistry A 2013, 117, 4223.

(179) Roberts, J. M. Atmospheric Environment Part a-General Topics 1990, 24, 243.

(180) Perring, A. E.; Pusede, S. E.; Cohen, R. C. Chemical Reviews 2013, 113, 5848.

(181) Amrani, A.; Said-Ahmad, W.; Shaked, Y.; Kiene, R. P. Proceedings of the National Academy of Sciences of the United States of America 2013, 110, 18413.

(182) Stefels, J.; Steinke, M.; Turner, S.; Malin, G.; Belviso, S. Biogeochemistry 2007, 83, 245.

(183) Andreae, M. O. Marine Chemistry 1990, 30, 1.

(184) Barnes, I.; Hjorth, J.; Mihalopoulos, N. Chemical Reviews 2006, 106, 940.

(185) Bates, T. S.; Kiene, R. P.; Wolfe, G. V.; Matrai, P. A.; Chavez, F. P.; Buck, K. R.; Blomquist, B. W.; Cuhel, R. L. Journal of Geophysical Research-Oceans 1994, 99, 7835.

(186) Bates, T. S.; Lamb, B. K.; Guenther, A.; Dignon, J.; Stoiber, R. E. Journal of Atmospheric Chemistry $1992,14,315$.

(187) Kloster, S.; Feichter, J.; Reimer, E. M.; Six, K. D.; Stier, P.; Wetzel, P. Biogeosciences 2006, 3, 29.

(188) Dincer, F.; Muezzinoglu, A. Atmospheric Environment 2006, 40, 4210.

(189) Charlson, R. J.; Lovelock, J. E.; Andreae, M. O.; Warren, S. G. Nature 1987, 326, 655.

(190) Lovelock, J. E. The Revenge of Gaia; Penguin Books: London, 2007.

(191) Stephens, E. R. Eos, Transactions American Geophysical Union 1987, 68, 89. 
(192) Stephens, E. R.; Hanst, P. L.; Doerr, R. C.; Scott, W. E. Industrial and Engineering Chemistry 1956, $48,1498$.

(193) Grosjean, D. Atmospheric Environment 2003, 37, S221.

(194) Fischer, E. V.; Jacob, D. J.; Yantosca, R. M.; Sulprizio, M. P.; Millet, D. B.; Mao, J.; Paulot, F.; Singh, H. B.; Roiger, A.; Ries, L.; Talbot, R. W.; Dzepina, K.; Deolal, S. P. Atmospheric Chemistry and Physics 2014, 14, 2679.

(195) Fantechi, G.; Vereecken, L.; Peeters, J. Physical Chemistry Chemical Physics 2002, 4, 5795.

(196) LaFranchi, B. W.; Wolfe, G. M.; Thornton, J. A.; Harrold, S. A.; Browne, E. C.; Min, K. E.; Wooldridge, P. J.; Gilman, J. B.; Kuster, W. C.; Goldan, P. D.; de Gouw, J. A.; McKay, M.; Goldstein, A. H.; Ren, X.; Mao, J.; Cohen, R. C. Atmospheric Chemistry and Physics 2009, 9, 7623.

(197) Peeters, J.; Vereecken, L.; Fantechi, G. Physical Chemistry Chemical Physics 2001, 3, 5489.

(198) Phillips, G. J.; Pouvesle, N.; Thieser, J.; Schuster, G.; Axinte, R.; Fischer, H.; Williams, J.; Lelieveld, J.; Crowley, J. N. Atmospheric Chemistry and Physics 2013, 13, 1129.

(199) Bottenheim, J. W.; Sirois, A.; Brice, K. A.; Gallant, A. J. Journal of Geophysical ResearchAtmospheres 1994, 99, 5333.

(200) Grosjean, D. Atmospheric Environment 1988, 22, 1637.

(201) Lee, J. B.; Yoon, J. S.; Jung, K.; Eom, S. W.; Chae, Y. Z.; Cho, S. J.; Kim, S. D.; Sohn, J. R.; Kim, K. H. Chemosphere 2013, 93, 1796. 
(202) Liu, Z.; Wang, Y. H.; Vrekoussis, M.; Richter, A.; Wittrock, F.; Burrows, J. P.; Shao, M.; Chang, C. C.; Liu, S. C.; Wang, H. L.; Chen, C. H. Geophysical Research Letters 2012, 39.

(203) Renzettj, N. A.; Bryan, R. J. Journal of the Air Pollution Control Association 1961, 11, 421.

(204) Singh, H. B.; Salas, L. J. Atmospheric Environment 1989, 23, 231.

(205) Whalley, L. K.; Lewis, A. C.; McQuaid, J. B.; Purvis, R. M.; Lee, J. D.; Stemmler, K.; Zellweger, C.; Ridgeon, P. Journal of Environmental Monitoring 2004, 6, 234.

(206) Williams, E. L.; Grosjean, E.; Grosjean, D. Journal of the Air \& Waste Management Association $1993,43,873$.

(207) Zhang, J. M.; Wang, T.; Ding, A. J.; Zhou, X. H.; Xue, L. K.; Poon, C. N.; Wu, W. S.; Gao, J.; Zuo, H. C.; Chen, J. M.; Zhang, X. C.; Fan, S. J. Atmospheric Environment 2009, 43, 228.

(208) Orlando, J. J.; Tyndall, G. S.; Calvert, J. G. Atmospheric Environment Part a-General Topics 1992, 26, 3111.

(209) Rollins, A. W.; Browne, E. C.; Min, K. E.; Pusede, S. E.; Wooldridge, P. J.; Gentner, D. R.; Goldstein, A. H.; Liu, S.; Day, D. A.; Russell, L. M.; Cohen, R. C. Science 2012, 337, 1210.

(210) Fry, J. L.; Kiendler-Scharr, A.; Rollins, A. W.; Brauers, T.; Brown, S. S.; Dorn, H. P.; Dube, W. P.; Fuchs, H.; Mensah, A.; Rohrer, F.; Tillmann, R.; Wahner, A.; Wooldridge, P. J.; Cohen, R. C. Atmospheric Chemistry and Physics 2011, 11, 3879.

(211) Carter, W. P. L.; Atkinson, R. Environmental Science \& Technology 1987, 21, 670. 
(212) Carter, W. P. L.; Pierce, J. A.; Luo, D. M.; Malkina, I. L. Atmospheric Environment 1995, 29, 2499.

(213) Anderssonskold, Y.; Grennfelt, P.; Pleijel, K. Journal of the Air \& Waste Management Association $1992,42,1152$.

(214) Derwent, R. G.; Jenkin, M. E. Atmospheric Environment Part a-General Topics 1991, 25, 1661.

(215) Derwent, R. G.; Jenkin, M. E.; Saunders, S. M. Atmospheric Environment 1996, 30, 181.

(216) Hough, A. M.; Derwent, R. G. Atmospheric Environment 1987, 21, 2015.

(217) Carter, W. P. L. Journal of the Air \& Waste Management Association 1994, 44, 881.

(218) Bowman, F. M.; Seinfeld, J. H. Atmospheric Environment 1994, 28, 3359.

(219) Jenkin, M. E.; Saunders, S. M.; Pilling, M. J. Atmospheric Environment 1997, 31, 81.

(220) Jenkin, M. E.; Saunders, S. M.; Wagner, V.; Pilling, M. J. Atmospheric Chemistry and Physics 2003, $3,181$.

(221) Saunders, S. M.; Jenkin, M. E.; Derwent, R. G.; Pilling, M. J. Atmospheric Chemistry and Physics 2003, 3, 161.

(222) Andersson-Skold, Y.; Holmberg, L. Atmospheric Environment 2000, 34, 3159.

(223) Cheng, H. R.; Guo, H.; Saunders, S. M.; Lam, S. H. M.; Jiang, F.; Wang, X. M.; Simpson, I. J.; Blake, D. R.; Louie, P. K. K.; Wang, T. J. Atmospheric Environment 2010, 44, 4199.

(224) Cheng, H. R.; Saunders, S. M.; Guo, H.; Louie, P. K. K.; Jiang, F. Environmental Pollution 2013, 180, 101. 
(225) IUPAC http://www.iupac.org/.

(226) Derwent, R. G.; Jenkin, M. E.; Pilling, M. J.; Carter, W. P. L.; Kaduwela, A. Journal of the Air \& Waste Management Association 2010, 60, 914.

(227) Niki, H.; Maker, P. D.; Savage, C. M.; Hurley, M. D. The Journal of Physical Chemistry 1987, 91, 2174.

(228) Wallington, T. J.; Andino, J. M.; Ball, J. C.; Japar, S. M. Journal of Atmospheric Chemistry 1990, 10, 301.

(229) Kaiser, E. W.; Pala, I. R.; Wallington, T. J. The Journal of Physical Chemistry A 2010, 114, 6850.

(230) Pinnock, S.; Hurley, M. D.; Shine, K. P.; Wallington, T. J.; Smyth, T. J. Journal of Geophysical Research: Atmospheres 1995, 100, 23227.

(231) Lovejoy, E. R.; Huey, L. G.; Hanson, D. R. Journal of Geophysical Research-Atmospheres 1995, 100, 18775.

(232) Schneider, W. F.; Wallington, T. J.; Huie, R. E. Journal of Physical Chemistry 1996, 100, 6097.

(233) Hurley, M. D.; Andersen, M. P. S.; Wallington, T. J.; Ellis, D. A.; Martin, J. W.; Mabury, S. A. Journal of Physical Chemistry A 2004, 108, 615. 
Abdelwahid Mellouki was born in Berkane, Morocco. His undergraduate and graduate studies were conducted in the Universities of Tours, Orleans and Paris 7 (France). He then spent two years as a Research Associate at the National Oceanic and Atmospheric Administration's Aeronomy Laboratory (Boulder-Colorado) under the supervision of Dr. A R. Ravishankara. Dr. Mellouki joined the scientific staff at CNRS in 1992, where he is currently a Research Director at the "Institut de Combustion, Aerothermique, Reactivite, et Environnement" (ICARE) in Orleans (France). He is leading the Atmospheric Reactivity Group. His research over the years has focused on many aspects of atmospheric chemistry, including the studies of the atmospheric oxidation mechanisms of anthropogenic and biogenic carbon-containing species and halogen chemistry. Dr. Mellouki has been involved in a number of EU programs related to atmospheric chemistry and air pollution. He is author or co-author of over 115 scientific publications related to atmospheric chemistry. He has been awarded the title of Guest Professor a the Research Center for Eco-Environmental Sciences (RCEES)-Chinese Academy of Sciences (CAS) and at Fudan University (Shanghai). In 2012, he was awarded the National Distinguished Professor title at Shandong University (Jinan-China). 


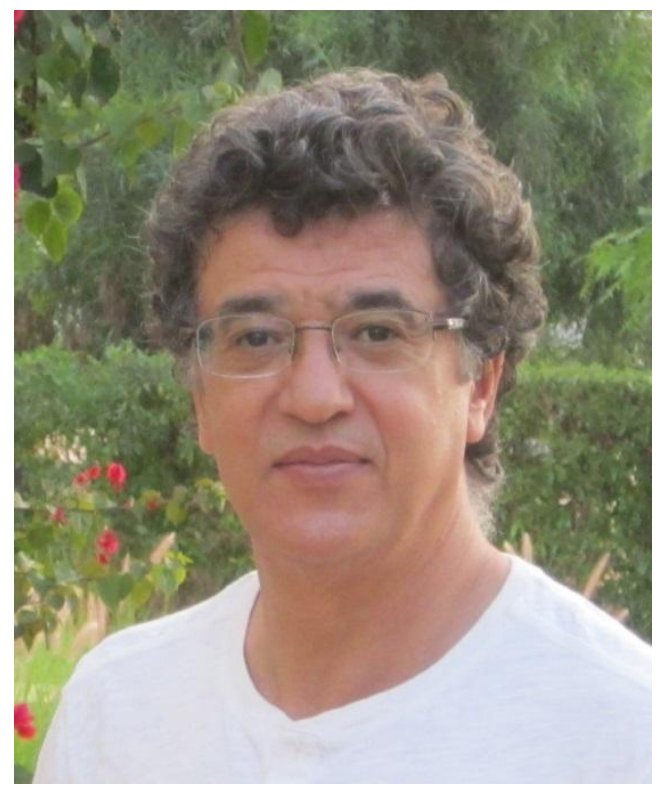


Timothy J. Wallington was born and educated in England. He received B.A. (1981), M.A.

(1982), D.Phil (1983), and D.Sc. (2007) degrees from Corpus Christi College, Oxford University where he studied with Professor R. P. Wayne and Dr. R. A. Cox. He carried out postgraduate research studies at the University of California, Los Angeles (1984-1986) with Professor J. N. Pitts and Dr. R. Atkinson. He was Guest Scientist at the U.S. National Bureau of Standards (1986-1987) with Dr. M. J. Kurylo. He joined the research staff at the Ford Motor Company in 1987 where he is currently the Senior Technical Leader for Environmental Sciences. He has carried out extensive research on various aspects of atmospheric chemistry and the kinetics and mechanisms of many different transient atmospheric species. He is co-author of over 450 peer reviewed scientific publications dealing with various aspects of air pollution chemistry. He is the recipient of seventeen Ford Research Publication Awards (1991-2014), two Henry Ford Technology Awards (1996, 2011), a Humboldt Research Fellowship at the Universität Wuppertal (1998-1999) with Professor K. H. Becker, the American Chemical Society Award in Industrial Chemistry (2008), and a USEPA Montreal Protocol Award (2011). He has an Honorary Doctorate in Science from Copenhagen University (2006) and an MBA from the University of Michigan (2003). 


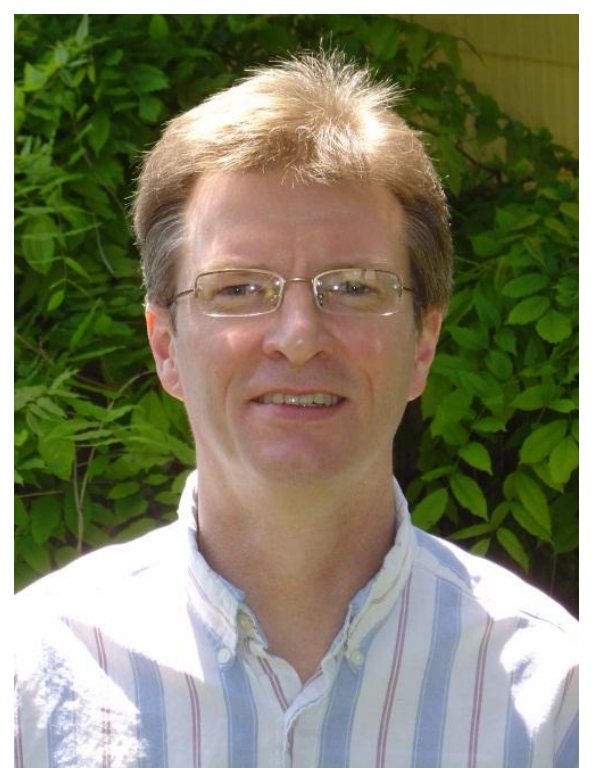


Jianmin Chen received his Ms. degree in Analytical Chemistry in 1990 and Ph.D. degree in Physical Chemistry from the Fudan University in 1993. Then, he was an Assistant Professor in the Department of Chemistry and an Associate Professor in the same University in 1995. After he studied heterogeneous catalysis as a visiting associate professor in the School of Engineering in the University of Pittsburgh for one year from 1996 to 1997, he joined in the Department of Environmental Science \& Engineering in the Fudan University and worked primarily on atmospheric heterogeneous and aerosol chemistry. He is currently a Distinguished Professor and the Director of the Shanghai Key Laboratory of Atmospheric Particle Pollution and Prevention $\left(\mathrm{LAP}^{3}\right)$ in the same University. He received the $1^{\text {st }}$ Rank of Natural Science by the Ministry of Education of China in 2009, and Bosteel Distinguished Professor in 2010. His research group now focuses on field measurement and laboratory studies of chamber simulation and heterogeneous reaction of aerosol. 


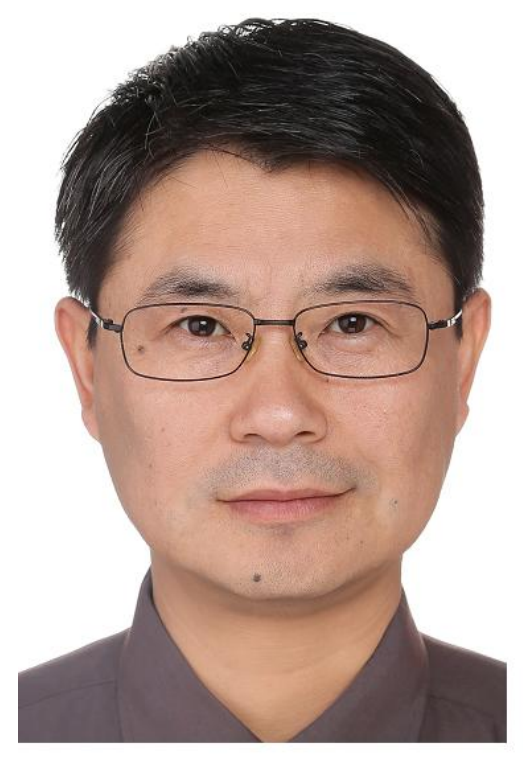

